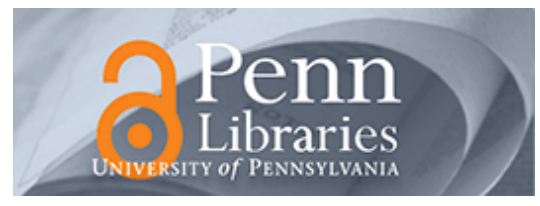

University of Pennsylvania

ScholarlyCommons

Management Papers

Wharton Faculty Research

6-1999

\title{
Do Domestic Firms Benefit From Direct Foreign Investment? Evidence From Venezuela
}

Brian J. Aitken

Ann E. Harrison

University of Pennsylvania

Follow this and additional works at: https://repository.upenn.edu/mgmt_papers

\section{Recommended Citation}

Aitken, B. J., \& Harrison, A. E. (1999). Do Domestic Firms Benefit From Direct Foreign Investment? Evidence From Venezuela. American Economic Review, 89 (3), 605-618. http://dx.doi.org/10.1257/ aer.89.3.605

This paper is posted at ScholarlyCommons. https://repository.upenn.edu/mgmt_papers/101

For more information, please contact repository@pobox.upenn.edu. 


\title{
Do Domestic Firms Benefit From Direct Foreign Investment? Evidence From Venezuela
}

\begin{abstract}
Governments often promote inward foreign investment to encourage technology 'spillovers' from foreign to domestic firms. Using panel data on Venezuelan plants, the authors find that foreign equity participation is positively correlated with plant productivity (the 'own-plant' effect), but this relationship is only robust for small enterprises. They then test for spillovers from joint ventures to plants with no foreign investment. Foreign investment negatively affects the productivity of domestically owned plants. The net impact of foreign investment, taking into account these two offsetting effects, is quite small. The gains from foreign investment appear to be entirely captured by joint ventures.
\end{abstract}




\title{
Do Domestic Firms Benefit from Direct Foreign Investment? Evidence from Venezuela
}

\author{
By Brian J. AitKen AND ANn E. Harrison*
}

\begin{abstract}
Governments often promote inward foreign investment to encourage technology "spillovers" from foreign to domestic firms. Using panel data on Venezuelan plants, we find that foreign equity participation is positively correlated with plant productivity (the "own-plant" effect), but this relationship is only robust for small enterprises. We then test for spillovers from joint ventures to plants with no foreign investment. Foreign investment negatively affects the productivity of domestically owned plants. The net impact of foreign investment, taking into account these two offsetting effects, is quite small. The gains from foreign investment appear to be entirely captured by joint ventures. (JEL F2, O1, O3).
\end{abstract}

In the 1990's, direct foreign investment (DFI) became the largest single source of external finance for developing countries. In 1997, DFI accounted for about half of all private capital and 40 percent of total capital flows to developing countries. Following the virtual disappearance of commercial bank lending in the 1980's, policy makers in emerging markets eased restrictions on incoming foreign investment. Many countries even tilted the balance by offering special incentives to foreign enterprises-including lower income taxes or income tax holidays, import duty exemptions, and subsidies for infrastructure. The rationale for this special treatment often stems from the belief that foreign investment generates externalities in the form of technology transfer.

Can these subsidies be justified? Apart from the employment and capital inflows which ac-

\footnotetext{
* Aitken: International Monetary Fund, 700 19th Street, NW, Washington, DC 20431; Harrison: Graduate School of Business, 615 Uris Hall, Columbia University, New York, NY 10027. The authors would like to thank three anonymous referees for very useful suggestions, as well as Susan Collins, John DiNardo, Rudi Dornbusch, Stan Fischer, David Genesove, Charles Himmelberg, Rob Porter, Ed Wolff, Mayra Zermeno, and seminar participants at Boston University, Brandeis University, Columbia University, Tufts University, MIT, Princeton University, the NBER International and Productivity Lunches, and the NBER Summer Institute participants for useful comments and discussion. We would also like to thank Esther Jones for wonderful administrative assistance.
}

company foreign investment, multinational activity may lead to technology transfer for domestic firms. ${ }^{1}$ If foreign firms introduce new products or processes to the domestic market, domestic firms may benefit from the accelerated diffusion of new technology (David J. Teece, 1977). In some cases, domestic firms may increase productivity simply by observing nearby foreign firms. In other cases, diffusion may occur from labor turnover as domestic employees move from foreign to domestic firms. Several studies have shown that foreign firms initiate more on-the-job training programs than their domestic counterparts (Ralph B. Edfelt, 1975; Reinaldo Gonclaves, 1986). If these benefits from foreign investment are not completely internalized by the incoming firm, some type of subsidy could be justified.

Case studies present mixed evidence on the role of foreign investment in generating technology transfer to domestic firms. In Mauritius and Bangladesh, studies suggest that the entry of several foreign firms led to the creation of a booming, domestically owned export industry for textiles (Jong Wong Rhee and Therese Belot, 1989). Edwin Mansfield and Anthony Romeo (1980), however, found that only a few of the 15 multinationals in their survey helped

\footnotetext{
${ }^{1}$ See Richard E. Caves (1982) and Gerald K. Helleiner (1989) for surveys of technology transfer and foreign direct investment.
} 
domestic firms acquire new technology. In a study of 65 subsidiaries in 12 developing countries, Dimitri Germidis (1977) found almost no evidence of technology transfer to local competitors. The lack of spillovers to domestic firms was attributed to a number of factors, including limited hiring of domestic employees in higherlevel positions, very little labor mobility between domestic firms and foreign subsidiaries, limited subcontracting to local firms, no research and development by the subsidiaries, and few incentives by multinationals to diffuse their knowledge to local competitors.

Few researchers have attempted to go beyond qualitative case study evidence. ${ }^{2}$ In this paper, we focus on two questions. First, to what extent do joint ventures or wholly owned foreign subsidiaries (hereafter referred to as "foreign" or "foreign-owned" firms) exhibit higher levels of productivity than their domestic counterparts? Second, is there any evidence of technology "spillovers" to domestically owned ("domestic") firms from these foreign entrants?

Using a richer data set, we are able to overcome important data restrictions faced by earlier researchers. In this paper, we use annual census data on over 4,000 Venezuelan firms, allowing us to measure the productivity effects of foreign ownership. Previous attempts to measure spillover effects from foreign investment faced a critical identification problem: if foreign invest-

\footnotetext{
${ }^{2}$ There are several exceptions, however. In a pioneering paper, Caves (1974) tested for the impact of foreign presence on value added per worker in Australian domestically owned manufacturing sectors. Caves found that the positive disparity between foreign and domestic value added per worker disappears as foreign firms employed an increasing share of the labor in the sector, which is consistent with the spillover hypothesis. Steven Globerman (1979) replicated Caves (1974) using sectoral, cross-section data for Canadian manufacturing industries in 1972. The results are consistent with a weak spillover effect. Magnus Blomstrom and Hakan Persson (1983), Blomstrom (1986), and Blomstrom and Edward W. Wolff (1989) focus on Mexico where-as a developing country - the gap between domestic and foreign productivity and the scope for spillovers may be larger. They generally find that sectors with higher foreign ownership exhibited higher levels of productivity, faster productivity growth, and faster convergence of productivity levels to U.S. norms. Blomstrom (1989) provides a synthesis of his previous work on the impact of foreign investment in Mexico.
}

ment gravitates towards more productive industries, then the observed correlation between the presence of foreign firms and the productivity of domestically owned firms will overstate the positive impact of foreign investment. As a result, one could find evidence of positive spillovers from foreign investment where no spillover occurs. Since we observe the behavior of each plant over time, we can control for fixed differences in productivity levels across industries which might affect the level of foreign investment. Our research confirms that these differences are in fact correlated with the pattern of foreign investment, biasing previous results.

We present two results. First, we find a positive relationship between increased foreign equity participation and plant performance, suggesting that individual plants do benefit from foreign investment. However, the positive own-plant effect is only robust for smaller plants, defined as plants with less than 50 employees. For large enterprises, the positive effects of foreign investment disappear when plant-specific differences are taken into account. This suggests that foreign investors are investing in the more productive plants. Second, productivity in domestically owned plants declines when foreign investment increases. This suggests a negative spillover from foreign to domestic enterprises, which we interpret as a market-stealing effect. If we add up the positive own-plant effect and the negative spillovers, on balance the impact of foreign investment on domestic plant productivity is quite small.

In Section I, we begin with a general discussion of the possible benefits as well as the costs of foreign investment. Section II discusses the Venezuelan data. Section III presents the estimation results and Section IV concludes the paper.

\section{Foreign Investment, Competition, and Technology Spillovers: The Framework}

The so-called "industrial organization" approach to foreign investment in manufacturing suggests that multinationals can compete locally with more informed domestic firms because multinationals possess nontangible productive assets, such as technological 
know-how, marketing and managing skills, export contacts, coordinated relationships with suppliers and customers, and reputation. ${ }^{3}$ Since the assets are almost always gained through experience, they cannot be easily licensed to host country firms, but can be transferred at a reasonable cost to subsidiaries who locate in the host country (Teece, 1977). If multinationals do indeed possess such nontangible assets, then we would expect foreign ownership to increase a firm's productivity.

In addition, domestically owned firms might benefit from the presence of foreign firms. Workers employed by foreign firms or participating in joint ventures may accumulate knowledge which is valued outside the firm. As experienced workers leave the foreign firms, this human capital becomes available to domestic firms, raising their measured productivity. Likewise, some firm-specific knowledge of the foreign owners might "spill over" to domestic industry as domestic firms are exposed to new products, production and marketing techniques, or receive technical support from upstream or downstream foreign firms. Foreign firms may also act as a stable source of demand for inputs in an industry, which can benefit upstream domestic firms by allowing them to train and maintain relationships with experienced employees. In all these cases, foreign presence would raise the productivity of domestically owned firms.

But foreign presence can also reduce productivity of domestically owned firms, particularly in the short run. If imperfectly competitive firms face fixed costs of production, a foreign firm with lower marginal costs will have an incentive to increase production relative to its domestic competitor. In this environment, entering foreign firms producing for the local market can draw demand from domestic firms, causing them to cut production. The productivity of domestic firms would fall as they spread their fixed costs over a smaller market, forcing them back up their average cost curves. If the productivity decline from this demand effect is

\footnotetext{
${ }^{3}$ See Stephen Hymer (1960), Caves (1971) and, more recently, Elhanan Helpman (1984) and Ignatius J. Horstmann and James R. Markusen (1989). For surveys, see Joseph M. Grieco (1986); Alan M. Rugman (1986).
}

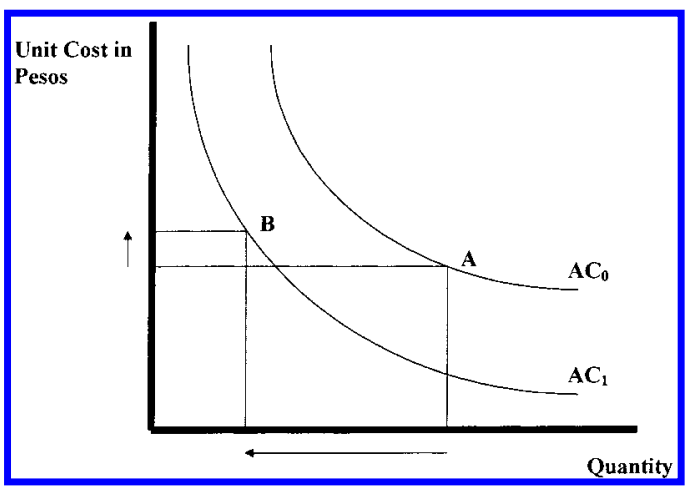

Figure 1. Output Response of Domestic Firms TO FOREIGN ENTRANTS

large enough, net domestic productivity can decline even if the multinational transfers technology or its firm-specific asset to domestic firms. These two offsetting effects were formally modelled by Aitken and Harrison (1997) and are depicted in Figure 1. Positive spillovers cause the domestic plant's average cost curve to fall from $\mathrm{AC}_{0}$ to $\mathrm{AC}_{1}$. However, the additional competition forces the plant to reduce output and move back up its new $\mathrm{AC}_{1}$ curve. The net effect in Figure 1 is to increase overall costs of production.

In this paper, we estimate log-linear production functions at the plant level to answer two basic questions: (1) whether foreign equity participation is associated with an increase in the plant's productivity, and (2) whether foreign ownership in an industry affects the productivity of domestically owned firms in the same industry-i.e., whether there are positive or negative "spillovers" to domestic enterprises. Both hypotheses (1) and (2) can be nested in the same general specification:

$$
\begin{aligned}
& Y_{i j t}=C+\beta_{1} \text { DFI_Plant }{ }_{i j t} \\
& +\beta_{2} \text { DFI_Sector }{ }_{j t} \\
& +\beta_{3} \text { DFI_Plant }{ }_{i j t} * D F I \_S e c t o r_{j t} \\
& +\beta_{4} \mathbf{X}_{i j t}+\varepsilon_{i j t} .
\end{aligned}
$$

Log output $Y_{i j t}$ for plant $i$ in sector $j$ at time $t$ is regressed on a vector of inputs $\mathbf{X}_{i j t}$ and two 
measures of foreign ownership. DFI_Plant is the share of foreign equity participation at the plant level, which varies between 0 and 100 percent. If foreign ownership in a plant increases that plant's productivity, we should observe a positive coefficient on DFI_Plant ${ }_{i j t}$. DFI_Sector ${ }_{j t}$ is a measure of the presence of foreign ownership in the industry, defined in more detail below. To the extent that the productivity advantages of foreign firms spill over to domestic firms, the coefficient on DFI_Sector $_{j t}$ should be positive. The coefficient on the interaction between plant-level and sector-level foreign investment (DFI_Plant $i_{i t} *$ DFI_Sector $_{j t}$ ) allows us to determine if the effects of foreign presence on other foreign firms differ from the effects on domestic firms. To the extent that plants with foreign investment benefit from the presence of other foreign plants, the coefficient should be positive. If joint ventures are negatively affected by the activities of other foreign plants, the coefficient should be negative.

\section{Data Description}

The data set employed in this paper was obtained directly from Venezuela's National Statistical Bureau, the Oficina Central de Estadistica e Informatica (OCEI). OCEI conducts an annual survey of industrial plants, known as the Enquesta Industrial. The years covered include 1976 through 1989, with the exception of 1980 (the industrial survey is not taken in census years). The industrial survey covers all plants in the formal sector with more than 50 workers, as well as a large sample of smaller plants. For the smaller plants, OCEI calculates the sample weights, permitting aggregation of output and other variables to estimate the importance of foreign investment in the local economy. The number of plants surveyed ranged from a low of 3,955 plants in 1982 to a high of 6,044 plants in 1978. The data set is not a balanced panel; the total number of plants varies across each year of the sample.

The original data set included 69,037 observations. To maintain confidentiality, the data set was released without plant identifiers. Consequently, we created a series of programs to relink the plants over time. In particular, we were able to use data collected on end-of-year capital stock and beginning-of-year capital stock to link many plants. Details on the birth of the plant, its location, ownership, number of employees, and other information were available to ensure that the linking process was not spurious. Nevertheless, we were unable to link 15,569 observations, which were omitted from the sample. A number of other observations were deleted because there were too few plants in the sector, because the plant had zero sales, employment, material inputs or investment, or because the data failed to satisfy other basic error checks. All these deletions reduced the sample size to 43,010 .

The data set contains information on foreign ownership, assets, output, employment, input costs, location, and product destination. DFI_Plant is defined as the percentage of subscribed capital (equity) owned by foreign investors. DFI_Sector is defined as foreign equity participation averaged over all plants in the sector, weighted by each plant's share in sectoral employment. In particular, foreign investment at the sectoral level is defined as:

$$
F S_{j t}=\frac{\sum_{i} F S_{i j t} * E \text { Emp }_{i j t}}{\sum_{i} \text { Employment }_{i j t}} .
$$

Since foreign firms tend to be more capital intensive than domestic firms, the share of foreign firms is significantly higher if weighted by physical capital. However, redoing the empirical analysis which follows using physical capital weights instead of employment weights leads to similar results. ${ }^{4}$

Output is defined as total output at the plant level, deflated by an annual producer price deflator which varies across four-digit industries. Skilled and unskilled labor is defined in terms of numbers of workers, rather than

\footnotetext{
${ }^{4}$ Foreign investment shares were computed using the original sample (prior to dropping any observations). In particular, OCEI's weights were used to reflate data which had been sampled, such as the smaller plants. This procedure was adopted in order to create a measure of foreign investment which corresponds as closely as possible to its overall sectoral share. Sector refers to the ISIC four-digit classification, which varies from 3111 to 3999.
} 
worker hours, which were not available over the entire sample.

The importance of foreign equity participation during 1976 through 1988 varied significantly across sectors (see Appendix Table A1, available upon request from the authors). The share of foreign equity was particularly high in scientific equipment (35 percent in 1988), tobacco (32 percent in 1988), and confectionery ( 25 percent). In other sectors, foreign investment was very small or zero (petroleum refining, textiles and apparel, fish canning, wood-working machinery). Some sectors, such as petroleum refining, were closed to foreign investment during the sample period. In addition to the cross-section variation, there were also large changes in the share of foreign investment over the sample period. Reforms initiated in 1986 and extended in 1990 are likely to increase even further the importance of foreign investment in the domestic economy. ${ }^{5}$

\footnotetext{
${ }^{5}$ Venezuelan firms are classified by degree of foreign ownership into three types: national, with less than 20percent foreign ownership; mixed with 20- to 49.9-percent foreign ownership; and foreign firms, with majority foreign control. Until 1989, the Superintendencia de Inversiones Extranjeras (SIEX) exercised substantial discretion in regulating the inflow of foreign investment. Profit remittances were limited to 20 percent (plus LIBOR) of the investment (based on book value). Since purchasing equity in existing firms was prohibited, foreign investment could only be in the form of direct investment registered with SIEX. Payments by a firm for its foreign partner's technology were prohibited, and contracts that called for royalty or patent payments needed SIEX approval.

During the period from 1975 to 1989 , foreign firms were discriminated against in a number of ways. First, they faced higher tax rates on corporate income- -50 percent versus 35 percent for domestic firms. They were also restricted from imposing confidentiality and exclusive use of trade secrets in joint ventures. Finally, foreign firms were obliged to buy bolivares at the official exchange rate rather than the freemarket rate. In 1989, the restriction on profit repatriation was eliminated. Bureaucratic discretion was eliminated and SIEX was authorized to reject foreign investment applications only if they did not comply with the sectoral restrictions discussed above. When exchange rates were unified following reforms, the discrepancy between official and free-market exchange rates was eliminated. The restrictions on use of confidentiality and trade secret requirements are currently being negotiated as part of agreements on property rights, and the differential tax rates between foreign and domestic firms are addressed in pending tax legislation.
}

\section{Effects of Foreign Investment on Productivity}

\section{A. Baseline Specification}

Table 1 reports the results for equation (1). The dependent variable, the log of real output for plant $i$ in sector $j$ at time $t$, is regressed on its inputs and on foreign equity participation. Plant-level inputs (expressed in logarithms) include unskilled labor $\left(U N S K L_{i t}\right)$, skilled labor $\left(S K L_{i t}\right)$, materials $\left(M_{i t}\right)$, and capital $\left(K_{i t}\right){ }^{6}$ In addition to a random component which varies across plants $\varepsilon_{i t}$, we allow for a time-varying component $D_{t}$ and control for productivity differences across industries by including fourdigit level ISIC dummies. All reported estimates include corrections for heteroskedasticity. As reported in the first column of Table 1, the coefficient on foreign ownership within the plant (Plant_DFI) is positive and statistically significant, suggesting that there are large productivity gains associated with foreign equity participation. The point estimate, 0.105 , suggests that output in plants which increased foreign equity participation from zero to 100 percent would be 10.5 percentage points higher than for comparable domestic plants. Since we already control for differences in inputs, this 10.5-percent increment is a pure total factor productivity gain.

\footnotetext{
${ }^{6}$ Output is calculated as the value of sales less the change in inventories, deflated by a four-digit level production (output) price deflator. Skilled and unskilled labor are measured as the number of skilled and unskilled employees. Although an ideal measure of labor input would be the number of hours worked, this information is only available for selected years. Material costs are adjusted for changes in inventories, then deflated by a production price deflator. Capital stock is the stock of capital reported by each firm at the beginning of the year, deflated by the GDP deflator. Due to space constraints, we do not report the coefficients on the inputs here. However, those are available from the authors upon request.

The producer price deflator that we use is an index for the using, not the supplying, industries. Ideally, we would want to calculate a material price deflator for each industry by using input-output tables to identify inputs, and take a weighted average of the price indices for those inputs. Unfortunately, no reliable input-output table for Venezuela was available. To the extent that output prices reflect underlying movements in the prices of material inputs, this approach is preferable to using an economywide price deflator.
} 
Table 1-Impact of Foreign Ownership on Total Factor Productivity:

Regressing Log Output at the Plant Level on InPuts and the Share of Foreign Ownership at the Plant and Sector LeVels ${ }^{\mathrm{a}}$

\begin{tabular}{|c|c|c|c|c|c|c|c|c|}
\hline & \multicolumn{2}{|c|}{$\begin{array}{l}\text { Impact of direct foreign } \\
\text { investment (DFI) on } \\
\text { productivity }\end{array}$} & \multicolumn{2}{|c|}{ Impact of DFI on output } & \multicolumn{4}{|c|}{ Impact of DFI on change in productivity } \\
\hline & $\begin{array}{l}\text { OLS with } \\
\text { industry } \\
\text { dummies } \\
\text { (1) }\end{array}$ & $\begin{array}{c}\text { OLS } \\
\text { without } \\
\text { industry } \\
\text { dummies } \\
\text { (2) }\end{array}$ & $\begin{array}{l}\text { Weighted } \\
\text { least } \\
\text { squares }^{\mathrm{c}} \\
\text { (3) }\end{array}$ & $\begin{array}{l}\text { OLS with } \\
\text { industry } \\
\text { dummies and } \\
\text { no factor } \\
\text { inputs } \\
\text { (4) }\end{array}$ & $\begin{array}{c}\text { First } \\
\text { differences } \\
\left(Y_{t}-Y_{t-1}\right) \\
(5)\end{array}$ & $\begin{array}{c}\text { Second } \\
\text { differences } \\
\left(Y_{t}-Y_{t-2}\right) \\
\text { (6) }\end{array}$ & $\begin{array}{c}\text { Third } \\
\text { differences } \\
\left(Y_{t}-Y_{t-3}\right) \\
(7)\end{array}$ & $\begin{array}{c}\text { Fourth } \\
\text { differences } \\
\left(Y_{t}-Y_{t-4}\right) \\
(8)\end{array}$ \\
\hline $\begin{array}{l}\text { Foreign ownership in the plant } \\
\quad(\text { Plant DFI })\end{array}$ & $\begin{array}{r}0.105 \\
(0.027)\end{array}$ & $\begin{array}{r}0.158 \\
(0.028)\end{array}$ & $\begin{array}{r}0.142 \\
(0.039)\end{array}$ & $\begin{array}{r}2.176 \\
(0.124)\end{array}$ & $\begin{array}{r}0.003 \\
(0.037)\end{array}$ & $\begin{array}{r}0.018 \\
(0.039)\end{array}$ & $\begin{array}{r}0.042 \\
(0.043)\end{array}$ & $\begin{array}{r}-0.011 \\
(0.049)\end{array}$ \\
\hline $\begin{array}{l}\text { Foreign ownership in the sector } \\
\quad(\text { Sector_DFI) }\end{array}$ & $\begin{array}{l}-0.267 \\
(0.061)\end{array}$ & $\begin{array}{r}0.058 \\
(0.030)\end{array}$ & $\begin{array}{l}-0.206 \\
(0.155)\end{array}$ & $\begin{array}{l}-1.258 \\
(0.232)\end{array}$ & $\begin{array}{r}-0.238 \\
(0.067)\end{array}$ & $\begin{array}{r}-0.302 \\
(0.065)\end{array}$ & $\begin{array}{l}-0.248 \\
(0.071)\end{array}$ & $\begin{array}{l}-0.320 \\
(0.083)\end{array}$ \\
\hline Plant_DFI $*$ Sector_DFI & $\begin{array}{r}0.356 \\
(0.181)\end{array}$ & $\begin{array}{l}-0.212 \\
(0.189)\end{array}$ & $\begin{array}{r}0.314 \\
(0.226)\end{array}$ & $\begin{array}{r}5.003 \\
(0.810)\end{array}$ & $\begin{array}{r}0.262 \\
(0.223)\end{array}$ & $\begin{array}{r}0.420 \\
(0.246)\end{array}$ & $\begin{array}{r}0.384 \\
(0.252)\end{array}$ & $\begin{array}{r}0.658 \\
(0.288)\end{array}$ \\
\hline Number of plants & 10,257 & 10,257 & 10,257 & 10,372 & 9,489 & 7,158 & 5,132 & 3,607 \\
\hline Number of observations & 43,010 & 43,010 & 43,010 & 46,947 & 32,521 & 23,136 & 16,100 & 11,045 \\
\hline Hausman test ${ }^{\mathrm{f}}$ & 38.4 & - & 82.9 & - & - & - & - & - \\
\hline$R^{2}$ & 0.96 & 0.95 & 0.96 & 0.32 & 0.53 & 0.60 & 0.64 & 0.65 \\
\hline
\end{tabular}

a All specifications include annual time dummies. All standard errors (denoted in parentheses) are corrected for heteroskedasticity. Unless otherwise specified, other independent variables (not reported here) include log materials, log skilled labor, $\log$ unskilled labor, and log capital stock. Plant_DFI is percentage of equity capital owned by foreigners. Sector_DFI is employment-weighted percentage of equity which is foreign owned at the four-digit ISIC level.

${ }^{\mathrm{b}}$ Industry dummies defined at the four-digit ISIC level.

${ }^{c}$ Weights are the share of each plant in total annual industry output. Industry dummies are also included.

${ }^{\mathrm{d}}$ Excludes the other independent variables described in note a above.

${ }^{e}$ Coefficients are estimated from a regression of changes in (log) output regressed on changes in $(\log )$ materials, skilled labor, unskilled labor, capital stock, changes in foreign investment at the plant and sector level, and annual time dummies.

${ }^{\mathrm{f}}$ In column (2), tests for equality of coefficients between ordinary least squares (OLS) and OLS with industry dummies. In column (3), tests for equality of coefficients (excluding the time dummies) between specifications in columns (2) and (3). Bootstrapping routine used to calculate variance-covariance matrix difference for test of OLS versus weighted least squares (WLS). For details, see John Dinardo et al. (1996). In column (2), the critical 5-percent value for the $\chi^{2}(19)=30.1$. In column (3), the critical 5-percent value for the $\chi^{2}(7)=14.1$. A higher value indicates rejection of the test.

In contrast, we find that domestic plants in sectors with more foreign ownership are significantly less productive than those in sectors with a smaller foreign presence. The point estimate for Sector_DFI in the second row of Table 1 is large in magnitude, significant, and negative. ${ }^{7}$

\footnotetext{
${ }^{7}$ While expressing foreign presence as a share (of labor or of sales) facilitates comparisons between large and small industries, the share's behavior over time is influenced both by changes in foreign investment (the numerator) and changes in the size of the industry (the denominator). For example, if foreign plants do not adjust quickly to economic downturns, while domestic firms react immediately, this would lead us to observe a rising foreign share during periods of economic decline. If productivity is procyclical, we would wrongly infer that foreign investment has a negative impact on domestic productivity. Therefore, we also tried splitting foreign share into its numerator and denominator and including each as individual regressors. The results, reported in an earlier version of the paper, are consistent with the estimates presented in Tables 1 through
}

The results imply that an increase in the share of foreign investment from 0 to 10 percent leads to as much as a 2.67-percentage-point decline in domestic productivity.

The coefficient on the interaction term, Plant_DFI *Sector_DFI, is positive and statistically significant. The positive coefficient suggests that for plants with foreign equity participation, there are positive spillovers from foreign investment-in contrast to domestic firms. Joint ventures benefit from foreign investment in the plant as well as from foreign investment in other plants within the same sector.

Our finding of large, negative spillovers from foreign investment to domestic firms is in sharp

3. The coefficient on foreign investment-measured as the number of employees in foreign enterprises-is negative and significant. 
contrast with previous econometric studies, which generally found positive spillovers. Previous researchers typically estimated some variant of equation (1) using a cross section of industries (rather than plants), where the coefficient on foreign share was interpreted as a measure of spillovers from foreign presence to domestic firms. Using data aggregated at the sectoral level, these studies were unable to control for differences in productivity across sectors which might be correlated with, but not caused by, foreign presence. If foreign investors gravitate towards more productive industries, then a specification which fails to control for differences across industries is likely to find a positive association between the share of DFI and the productivity of domestic plants even if no spillovers take place.

Evidence from Venezuela suggests this to be the case. We reestimate equation (1) without controlling for industry-specific productivity differences, a specification which is closest in spirit to earlier cross-section studies. The coefficient on Sector_DFI is now positive and statistically significant, which is consistent with the results of previous research (second column of Table 1). The point estimate suggests that the productivity of domestic firms is higher by 0.58 percent in industries with 10 percentage points more foreign share of employment. The coefficient on Plant_DFI is also larger in magnitude, rising to 0.158 from 0.105 , while the interaction term is insignificant. A chi-square (Hausman) test for equality of coefficients across the two specifications in columns (1) and (2) is rejected, confirming that the differences are statistically significant.

The very different message suggested by the results in columns (1) and (2) provides an excellent example of the problems associated with cross-section estimation. If we fail to control for the fact that foreign investment is attracted to more productive sectors, we conclude that spillovers from foreign ownership are positive; once we introduce controls for industry-specific differences, however, we find evidence of negative spillovers on domestic productivity.

In column (3), we reestimate equation (1) using weighted least squares (WLS). The weights are given by each plant's share in employment. WLS allows us to attach greater importance to large plants in determining the overall impact of foreign investment. If we find significant differences between the coefficient estimates presented in columns (1) and (3), this would imply that foreign investment has different effects across small and large plants.

Under WLS, the results are qualitatively similar, with positive own-plant effects and negative spillovers. However, the positive impact of plant-level equity participation increases and the negative spillovers to domestically owned enterprises are smaller than reported in column (1). The results of the chi-square test suggest that these differences between OLS and WLS are statistically significant. In particular, it is likely that both the own-plant effect and the magnitude of negative spillovers vary systematically with plant size. We focus explicitly on the differences across small and large plants later in the paper.

Interpreted in the context of the framework discussed in Section II, the negative coefficient on Sector_DFI is consistent with a large detrimental impact of foreign investment on the scale of domestically owned production. We can test the implications of Figure 1 directly by observing whether the output of domestically owned firms contracts in response to a rise in foreign share. To do this, we simply reestimate equation (1), excluding plant-level inputs, which measures the relationship between domestic output levels and foreign presence. In the fourth column of Table 1, the coefficient on foreign share is large, negative, and statistically significant. The point estimate, -1.258 , suggests that an increase in the share of foreign investment would lead to more than an equal and opposite decline in domestic output. If foreign investors increased their share of total sales in an industry by 10 percentage points, output produced by plants without foreign investment in that industry would decline by 12.58 percentage points. These results suggest that foreign investment reduces domestic plant productivity in the short run by forcing domestic firms to contract, thereby increasing their average costs.

As a further test for the robustness of the estimates, we reestimate equation (1) taking first-difference and long-difference transformations of the data (last four columns of Table 1). We begin with a first-difference transformation 
of the data and then move to a maximum of four-year differences. ${ }^{8}$ Transforming the data into differences allows us to control for any fixed effects which could be present at the plant, instead of the industry, level. For example, the positive coefficient on Plant_DFI could arise from the fact that foreigners purchase shares in only the most productive domestic firms.

In the long-difference specifications, the coefficient on Sector_DFI remains negative and significant. It also increases in magnitude as we move from first to fourth differences, suggesting that the negative impact of foreign investment on domestic competitors does not quickly disappear but actually rises over time. The coefficient on Plant_DFI becomes small in sign and statistically insignificant, suggesting that the positive own-plant effects could arise from the fact that foreign investors are simply investing in the most productive firms. However, the coefficient on the interaction term remains positive and is significant at the 5-percent level. These results suggest that joint ventures do benefit from direct investment, but that the benefits are concentrated in sectors with a high share of foreign investment.

Overall, the evidence in Table 1 suggests that the positive impact of foreign investment on the productivity of domestically owned firms reported in some earlier studies is not robust when we control for differences in industry productivity. Foreign investors in Venezuela tend to locate in more productive industries, and increases in foreign investment lead to a decline in the productivity of domestic firms.

\section{B. Could Spillovers Be "Local"?}

One possible source of misspecification is that foreign investors generate positive technology spillovers, but only for plants located nearby. We might not observe these "local" benefits when we measure the impact of foreign investment for domestic firms in all regions if the benefits are too small to offset the overall negative impact across all regions.

There are reasons to expect that any benefits

\footnotetext{
${ }^{8}$ Since the panel is unbalanced, the number of observations declines as we take differences over a longer time horizon.
}

to domestic firms from foreign investment would be received first by their neighbors before they diffuse to other domestic firms. Whether trained workers leave the joint venture to work at nearby domestic firms, or whether the joint venture demonstrates a product, process, or market previously unknown to domestic owners, the benefits are likely to be captured first by neighboring domestic firms, and perhaps gradually spread to other, more distant domestic firms. If the positive benefits from foreign investment are received mainly by local firms, while the negative impact on market share is more widespread due to the importance of national instead of local markets, it should be possible to use the regional distribution of foreign investment to disentangle these offsetting effects.

To test for the possibility that technology is transferred at the local level, we broaden the analysis to include both regional and sectoral foreign share variables in the same regression. We measure regional foreign presence in the same way as national foreign presence; that is, we include in our estimation the share of employment in industry $j$ in location $s$ employed by foreign firms, denoted Local_Sector_DFI ${ }_{j s t}$.

If foreign firms are attracted to regions which benefit from agglomeration economies or better infrastructure, then the coefficient on Local_Sector_DFI could overestimate the positive impact of location-specific foreign investment on productivity. We address the possibility of an unobserved location fixed effect in two ways. First, we introduce proxy variables which reflect regional productivity differences. One such variable is the real wage of skilled workers, measured over all

\footnotetext{
${ }^{9}$ We determine the location based on the Venezuelan Manufacturing Census. The census divides Venezuela into 23 regions, which in turn are subdivided into districts. Regions may have several or as many as 20 districts. In all, the total number of districts adds up to 220 separate locations, the level at which we conduct our estimation. In a country one-third larger than the state of Texas, this indicates that the average district size is 40 miles wide by 40 miles long (1,600 square miles). We calculated the average share of labor employed at foreign-owned firms for each industry and the standard deviation of this measure across districts. The size of the standard deviations indicates that foreign presence is quite unevenly distributed both across industries and across regions. In addition, most of the foreign investment is located in regions other than Caracas.
} 
Table 2-EfFects of Foreign Ownership in the Region on Total Factor Productivity: Regressing Log Output at the Plant Level on InPuts and the Share of Foreign Ownership at the Plant LeVel, the Sector Level, and the Local Level ${ }^{a}$

\begin{tabular}{|c|c|c|c|c|}
\hline & \multicolumn{2}{|c|}{ OLS with industry dummies ${ }^{\mathrm{b}}$} & \multicolumn{2}{|c|}{ Within estimates $^{\mathrm{c}}$} \\
\hline & (1) & (2) & (3) & (4) \\
\hline & $\begin{array}{l}\text { No regional } \\
\text { controls }\end{array}$ & $\begin{array}{l}\text { With regional } \\
\text { controls }^{\mathrm{d}}\end{array}$ & $\begin{array}{l}\text { No regional } \\
\text { controls }\end{array}$ & $\begin{array}{l}\text { With regional } \\
\text { controls }^{\mathrm{d}}\end{array}$ \\
\hline \multirow{2}{*}{$\begin{array}{l}\text { Foreign ownership in the plant } \\
\quad(\text { Plant_DFI })\end{array}$} & 0.161 & 0.154 & 0.063 & 0.067 \\
\hline & $(0.030)$ & $(0.031)$ & $(0.039)$ & $(0.040)$ \\
\hline \multirow{2}{*}{$\begin{array}{l}\text { Foreign ownership in the sector and region } \\
\text { (Local_Sector_DFI) }\end{array}$} & 0.068 & 0.015 & 0.035 & 0.040 \\
\hline & $(0.023)$ & $(0.024)$ & $(0.032)$ & $(0.034)$ \\
\hline \multirow{2}{*}{ Plant_DFI*Local_Sector_DFI } & -0.357 & -0.271 & -0.165 & -0.189 \\
\hline & $(0.066)$ & $(0.068)$ & $(0.077)$ & $(0.080)$ \\
\hline \multirow{2}{*}{$\begin{array}{l}\text { Foreign ownership in the sector over all regions } \\
\quad(\text { Sector_DFI) }\end{array}$} & -0.290 & -0.289 & -0.317 & -0.304 \\
\hline & $(0.062)$ & $(0.063)$ & $(0.055)$ & $(0.057)$ \\
\hline \multirow[t]{2}{*}{ Plant_DFI $*$ Sector_DFI } & 0.694 & 0.685 & 0.418 & 0.415 \\
\hline & $(0.190)$ & $(0.197)$ & $(0.206)$ & $(0.215)$ \\
\hline Number of observations & 43,010 & 41,333 & 43,010 & 41,333 \\
\hline Number of plants & 10,257 & 10,190 & 10,257 & 10,190 \\
\hline$R^{2}$ & 0.96 & 0.96 & 0.98 & 0.98 \\
\hline
\end{tabular}

a All specifications include annual time dummies. All standard errors (denoted in parentheses) are corrected for heteroskedasticity. Unless otherwise specified, other independent variables (not reported here) include log materials, log skilled labor, log unskilled labor, and log capital stock. Plant_DFI is percentage of equity owned by foreigners. Sector_DFI is employmentweighted percentage of equity which is foreign owned at the four-digit ISIC level.

${ }^{\mathrm{b}}$ Industry dummies defined at the four-digit ISIC level.

${ }^{\mathrm{c}}$ Estimated by subtracting from each variable its plant specific mean over all years.

${ }^{\mathrm{d}}$ Regional controls include the real skilled wage and energy prices.

industries in the region. Variations in the real wage for skilled workers across regions could reflect locational advantages such as infrastructural differences, local agglomeration economies, or unobserved differences in the quality of labor. James E. Rauch (1991), for example, provides empirical evidence for the United States that variations in human capital accumulation across cities are reflected in higher wages for individuals. Since foreign investment in any one four-digit industry is unlikely to affect significantly the skilled wage for all industries in the region, the skilled wage across all industries should capture regional rather than industry-specific factors. Another factor which can be used to capture exogenous differences in productivity across regions in Venezuela is the price of energy. The Venezuelan government encouraged relocation to some regions by implementing uneven energy subsidies across regions, which could lead to apparent differences in productivity.

Second, we estimate plant-level "within" estimates by subtracting from each variable its plant-specific mean over time. To the extent that those regional differences in productivity which might be correlated with foreign investment are relatively fixed over the sample period, this specification will produce unbiased estimates of the impact of regional foreign investment on productivity.

Using both estimation methods, we find little evidence for spillovers from local foreign investment (Table 2). The coefficients on countrywide foreign investment are negative and significant as before. If proxies for regional productivity are excluded, the coefficient on regional foreign investment is positive, albeit only marginally statistically significant [column (1)]. When wages for skilled workers and electricity prices are included, however, the coefficient on regional foreign investment becomes small in magnitude and insignificant [column (2)]. Individual firm productivity is consistently positively correlated with the real skilled wage and negatively correlated with electricity prices, as expected. This suggests that foreign investment is likely to locate in areas with highly 
productive skilled workers and lower energy prices, biasing the unadjusted estimates of the impact of regional foreign share upwards.

Despite the addition of regional foreign investment, the coefficients on Sector_DFI (countrywide, sectoral DFI) remain negative and significant in all specifications, with magnitudes similar to those reported in Table 1 . The coefficient on Plant_DFI * All_DFI also remains positive and significant, indicating positive spillovers from sector-level DFI to plants with foreign equity. However, the interaction between Plant_DFI and Local_Sector_DFI is negative, suggesting that foreign plants do not benefit from foreign investors located nearby. Foreign plants benefit from a high overall level of DFI in the sector but may be hurt by foreign competitors in the same sector and geographic area.

The within estimates, reported in columns (3) and (4), yield similar results. There is no statistically significant impact of region-specific foreign investment on domestic firm productivity. The positive coefficient on foreign investment at the plant level (Plant_DFI) becomes small in magnitude and insignificant, which is consistent with the long-difference results in Table 1. As before, the positive coefficient on Plant_DFI* All_DFI indicates that the beneficial impact of DFI is restricted to foreign plants located in sectors with high levels of DFI.

The results in Tables 1 and 2 are robust over a variety of alternative specifications. In addition to experimenting with other measures which might reflect location-specific productivity differences, such as the number of firms in each location, we tested several variations on the definition of foreign share. ${ }^{10}$ These alternative specifications yielded no significant differences. Alternatively, we explored the possibility

\footnotetext{
${ }^{10}$ We reestimated equation (1) using two alternative definitions for foreign share. First, foreign share was redefined as the total number of employees in plants where at least 5 percent of assets are foreign owned, divided by the total number of employees in all plants in that sector. Second, foreign share was redefined as a zero-one variable, equal to one if there is any foreign investment at all in a region. The rationale for this specification is that the impact of foreign investment may be nonlinear, with one foreign plant in a sector potentially having as much impact on technology transfer as several foreign firms. These definitions, however, produce results similar to those in Tables 1 and 2 .
}

that technology transfer from foreign firms takes place slowly, and that the positive impact of foreign on domestic productivity is observed only after several years. To examine the impact of foreign investment on domestic firm productivity growth over a longer time horizon, we estimated the same specification in equation (1) but substituted lagged values for the shares of both national and regional foreign ownership. We allowed lags of up to eight years. ${ }^{11}$ Our previous results remain unchanged. We continue to see a strong, negative impact of sectoral foreign share and a generally insignificant impact of local (regional) foreign share on productivity.

We conclude that there is no empirical support for the hypothesis that technology is transferred locally from joint ventures to domestically owned firms. Our empirical results confirm case study evidence for Venezuela, which claims few cases of technology transfer from multinationals to domestically owned firms (see, for example, Luis Matos, 1977).

\section{Small versus Large Plants}

The differences between the OLS and WLS results presented in Table 1 imply systematic differences across small and large plants. In Table 3, we report the coefficients from OLS and within estimation separately for small and large plants. Large plants are defined as plants with a mean of at least 50 employees over the entire sample period.

Although the results are consistent with those reported in Tables 1 and 2, some interesting differences appear. In particular, the positive own-plant effect is only robust for small plants. For small plants, the coefficient on Plant_DFI varies between 0.104 and 0.182 , indicating that a 10 -percentage-point increase in foreign equity participation would

\footnotetext{
${ }^{11}$ Similarly, we estimated the same specification as equation (1), but instead regressed the difference between current and lagged output as a function of the difference between each independent variable and its lag. We allowed differences of up to seven years. The results were similar to those we obtained by simply including lagged values of the foreign share variables.
} 
Table 3-Impact of Foreign Ownership by Plant Size:

Regressing Log Output at the Plant LeVel on InPuts and the Share of Foreign Ownership at the Plant Level, the Sector Level, and the Local Level ${ }^{a}$

\begin{tabular}{|c|c|c|c|c|c|c|c|c|}
\hline & \multicolumn{4}{|c|}{ Small plants (less than or equal to 49 employees) } & \multicolumn{4}{|c|}{ Large plant (greater than 49 employees) } \\
\hline & $\begin{array}{l}\text { (1) } \\
\text { OLS }\end{array}$ & $\begin{array}{c}(2) \\
\text { Within }^{\mathrm{b}}\end{array}$ & $\begin{array}{l}(3) \\
\text { OLS }\end{array}$ & $\begin{array}{c}\text { (4) } \\
\text { Within }^{\mathrm{b}}\end{array}$ & $\begin{array}{c}(5) \\
O L S^{\mathrm{c}}\end{array}$ & $\begin{array}{c}\text { (6) } \\
\text { Within }^{\mathrm{b}, \mathrm{c}}\end{array}$ & $\begin{array}{c}(7) \\
\mathrm{OLS}^{\mathrm{c}}\end{array}$ & $\begin{array}{c}\text { (8) } \\
\text { Within }\end{array}$ \\
\hline $\begin{array}{l}\text { Foreign ownership in the plant } \\
\quad(\text { Plant_DFI) }\end{array}$ & $\begin{array}{r}0.104 \\
(0.052)\end{array}$ & $\begin{array}{r}0.100 \\
(0.055)\end{array}$ & $\begin{array}{r}0.167 \\
(0.065)\end{array}$ & $\begin{array}{r}0.182 \\
(0.084)\end{array}$ & $\begin{array}{r}0.121 \\
(0.031)\end{array}$ & $\begin{array}{l}-0.018 \\
(0.049)\end{array}$ & $\begin{array}{r}0.174 \\
(0.036)\end{array}$ & $\begin{array}{r}-0.123 \\
(0.073)\end{array}$ \\
\hline $\begin{array}{l}\text { Foreign ownership in the sector and } \\
\text { region } \\
\text { (Local Sector DFI) }\end{array}$ & - & - & $\begin{array}{r}0.061 \\
(0.035)\end{array}$ & $\begin{array}{r}0.072 \\
(0.058)\end{array}$ & - & - & $\begin{array}{l}-0.020 \\
(0.032)\end{array}$ & $\begin{array}{r}0.196 \\
(0.218)\end{array}$ \\
\hline Plant_DFI * Local_Sector_DFI & - & - & $\begin{array}{r}-0.395 \\
(0.138)\end{array}$ & $\begin{array}{r}-0.359 \\
(0.170)\end{array}$ & - & - & $\begin{array}{r}-0.203 \\
(0.080)\end{array}$ & $\begin{array}{r}-0.285 \\
(0.247)\end{array}$ \\
\hline $\begin{array}{l}\text { Foreign ownership in the sector over all } \\
\text { regions) } \\
\text { (Sector_DFI) }\end{array}$ & $\begin{array}{l}-0.349 \\
(0.074)\end{array}$ & $\begin{array}{l}-0.340 \\
(0.074)\end{array}$ & $\begin{array}{l}-0.366 \\
(0.076)\end{array}$ & $\begin{array}{l}-0.363 \\
(0.093)\end{array}$ & $\begin{array}{l}-0.127 \\
(0.105)\end{array}$ & $\begin{array}{l}-0.214 \\
(0.111)\end{array}$ & $\begin{array}{r}-0.128 \\
(0.113)\end{array}$ & $\begin{array}{r}-0.180 \\
(0.173)\end{array}$ \\
\hline Plant_DFI*Sector_DFI & $\begin{array}{r}1.184 \\
(0.595)\end{array}$ & $\begin{array}{r}0.046 \\
(0.564)\end{array}$ & $\begin{array}{r}1.475 \\
(0.584)\end{array}$ & $\begin{array}{r}0.559 \\
(0.837)\end{array}$ & $\begin{array}{r}0.351 \\
(0.205)\end{array}$ & $\begin{array}{r}0.411 \\
(0.279)\end{array}$ & $\begin{array}{r}0.590 \\
(0.225)\end{array}$ & $\begin{array}{r}1.033 \\
(0.372)\end{array}$ \\
\hline Number of observations & 29,179 & 29,179 & 28,069 & 28,069 & 13,831 & 13,831 & 13,264 & 13,264 \\
\hline Number of plants & 7,620 & 7,620 & 7,563 & 7,563 & 2,637 & 2,637 & 2,627 & 2,627 \\
\hline$R^{2}$ & 0.90 & 0.96 & 0.90 & 0.94 & 0.90 & 0.94 & 0.90 & 0.96 \\
\hline
\end{tabular}

${ }^{a}$ Industry dummies included in all OLS specifications. All standard errors (denoted in parentheses) are corrected for heteroskedasticity. Unless otherwise specified, other independent variables (not reported here) include log materials, log skilled labor, $\log$ unskilled labor, and log capital stock. Plant_DFI is percentage of equity owned by foreigners. Sector_DFI is employment-weighted percentage of equity which is foreign owned at the four-digit ISIC level.

${ }^{\mathrm{b}}$ Estimated by subtracting from each variable its plant-specific mean over all years.

${ }^{\mathrm{c}}$ Regional controls include the real skilled wage and energy prices.

be associated with an increase in productivity of between 0.1 and 0.2 percentage points. For large plants, however, the coefficient on Plant_DFI is not robust across specifications, becoming insignificantly different from zero when we take into account plant-specific effects. The results suggest that the lack of robustness in the own-plant effect identified in Tables 1 and 2 are due entirely to large plants. Across these plants, foreign investors apparently target the more productive enterprises. For small plants, however, there appears to be a strong, independent positive effect of foreign equity participation on productivity levels.

The spillover effects of DFI, captured by Sector_DFI, also vary across plant size. The point estimates are negative for both small and large plants, but the magnitudes are double or triple in size for small plants, suggesting a much larger market-stealing effect. In addition, the coefficients are only significant for small plants, suggesting that (negative) spillovers are concentrated on smaller enterprises who cannot compete as effectively with foreign entrants as their larger domestic competitors.

\section{Overall Effects of Foreign Investment}

The results point to two quite different conclusions about the impact of foreign investment on productivity in Venezuela's manufacturing sector. On the one hand, plants with higher foreign participation exhibit positive productivity gains - although these results are only robust for smaller plants. On the other hand, plants which do not receive foreign investment exhibit productivity declines as a result of increasing foreign activity. We now measure the net impact of these two offsetting forces.

We use the following approach to determine the overall effect of foreign investment on the productivity of the manufacturing sector. Using the coefficient estimates reported in Tables 1 through 3 and the actual values of Plant_DFI, Sector_DFI, and Local_Sector_DFI, we get a net effect of DFI for each plant. We then sum this effect across all firms, weighted by the value of the firm's production, to derive the net effect on Venezuelan manufacturing for each year. In Table 4, we report the average effect over all years.

The net impact of DFI is small in magnitude and positive if we use WLS, but negative 
Table 4-Net Impact of Foreign Ownership on Total Factor Productivity in the Economy: Weighted Regression of Output at the Plant Level on InPuts and the Share of Foreign Ownership at the Plant and Sector LeVels ${ }^{\mathrm{a}}$

\begin{tabular}{|c|c|c|c|c|c|}
\hline & \multicolumn{2}{|c|}{ National effects only } & \multicolumn{3}{|c|}{ National and regional effects } \\
\hline & $\begin{array}{c}\mathrm{OLS}^{\mathrm{b}} \\
(1)\end{array}$ & $\begin{array}{c}\text { Weighted } \\
\text { least squares } \\
\text { (2) }\end{array}$ & $\begin{array}{l}\mathrm{OLS}^{\mathrm{d}} \\
\text { (3) }\end{array}$ & $\begin{array}{l}\text { Within: } \\
\text { Small plants } \\
\text { (4) }\end{array}$ & $\begin{array}{l}\text { Within: } \\
\text { Large plants } \\
\text { (5) }\end{array}$ \\
\hline $\begin{array}{l}\text { Foreign ownership in the plant } \\
\quad(\text { Plant_DFI })\end{array}$ & $\begin{array}{r}0.105 \\
(0.027)\end{array}$ & $\begin{array}{r}0.142 \\
(0.039)\end{array}$ & $\begin{array}{r}0.154 \\
(0.031)\end{array}$ & $\begin{array}{r}0.182 \\
(0.084)\end{array}$ & $\begin{array}{l}-0.123 \\
(0.073)\end{array}$ \\
\hline $\begin{array}{l}\text { Foreign ownership in the sector } \\
\text { and region } \\
\quad \text { (Local_Sector_DFI) }\end{array}$ & - & - & $\begin{array}{r}0.015 \\
(0.024)\end{array}$ & $\begin{array}{r}0.072 \\
(0.058)\end{array}$ & $\begin{array}{r}0.196 \\
(0.218)\end{array}$ \\
\hline Plant_DFI * Local_Sector_DFI & - & - & $\begin{array}{r}-0.271 \\
(0.068)\end{array}$ & $\begin{array}{l}-0.359 \\
(0.170)\end{array}$ & $\begin{array}{l}-0.295 \\
(0.247)\end{array}$ \\
\hline $\begin{array}{l}\text { Foreign ownership in the sector } \\
\text { over all regions } \\
\text { (Sector_DFI) }\end{array}$ & $\begin{array}{l}-0.267 \\
(0.061)\end{array}$ & $\begin{array}{l}-0.206 \\
(0.155)\end{array}$ & $\begin{array}{r}-0.289 \\
(0.063)\end{array}$ & $\begin{array}{l}-0.363 \\
(0.093)\end{array}$ & $\begin{array}{r}-0.180 \\
(0.173)\end{array}$ \\
\hline Plant_DFI $*$ Sector_DFI & $\begin{array}{r}0.356 \\
(0.181)\end{array}$ & $\begin{array}{r}0.314 \\
(0.226)\end{array}$ & $\begin{array}{r}0.685 \\
(0.197)\end{array}$ & $\begin{array}{r}0.559 \\
(0.837)\end{array}$ & $\begin{array}{r}1.033 \\
(0.372)\end{array}$ \\
\hline Net impact of $\mathrm{DFI}^{\mathrm{g}}$ & -0.0068 & 0.0004 & -0.0072 & -0.0100 & -0.0043 \\
\hline Number of observations & 43,010 & 43,010 & 41,333 & 28,069 & 13,264 \\
\hline
\end{tabular}

${ }^{\text {a }}$ All specifications include annual time dummies. All standard errors (denoted in parentheses) are corrected for heteroskedasticity. Unless otherwise specified, other independent variables (not reported here) include log materials, log skilled labor, $\log$ unskilled labor, and log capital stock. Plant_DFI is percent of equity owned by foreigners. Sector_DFI is employmentweighted percent of equity which is foreign owned at the four-digit ISIC level.

${ }^{\mathrm{b}}$ Coefficients are taken from the first column of Table 1.

${ }^{\mathrm{c}}$ Coefficients are taken from the third column of Table 1. Weighted by the plant's share of total employment.

${ }^{\mathrm{d}}$ Coefficients are taken from the second column of Table 2 .

${ }^{\mathrm{e}}$ Coefficients are taken from the fourth column of Table 3.

${ }^{\mathrm{f}}$ Coefficients are taken from the eighth column of Table 3.

${ }^{g}$ The net impact of DFI is calculated by multiplying the coefficients in the first five rows by their actual values and then adding them together for each plant. We then sum this net effect across all plants, weighted by each plant's share of employment. The reported net effect is the average across all years.

overall using OLS or plant-level within estimates. The point estimates using unweighted OLS suggest that the net impact of foreign investment is to reduce total factor productivity levels by 0.7 percentage points annually. The weighted estimates, however, suggest a very small overall net gain: DFI raises plant total factor productivity by 0.04 percentage points a year. The within estimates, which lead to negative own-plant effects for large enterprises, suggest a negative overall impact of DFI of 1 percentage point a year for small plants and 0.4 percentage points a year for large plants, adding up to a 1.4-percentagepoint decline annually. Even if we focus only on the WLS estimates, which assign a greater weight to large enterprises, the evidence suggests that the plant-level gains only slightly outweigh the negative spillover effects.

\section{Conclusion}

Using a panel of more than 4,000 Venezuelan plants between 1976 and 1989, we identify two effects of foreign direct investment on domestic enterprises. First, we find that increases in foreign equity participation are correlated with increases in productivity for recipient plants with less than 50 employees, suggesting that these plants benefit from the productive advantages of foreign owners. Second, we find that increases in foreign ownership negatively affect the productivity of wholly domestically owned firms in the same industry. These negative effects are large and robust to alternative model specifications. Although previous studies generally found positive effects, we show that these results can be explained by the tendency for multinationals 
to locate in more productive sectors and to invest in more productive plants.

On balance, our evidence suggests that the net effect of foreign ownership on the economy is quite small. Weighted least-squares estimates suggest that the positive effects for recipient firms slightly outweigh the negative effects on firms that remain domestically owned; other approaches yield a net negative impact of DFI. We conclude that there are benefits from foreign investment, but that such benefits appear to be internalized by joint ventures. We find no evidence supporting the existence of technology "spillovers" from foreign firms to domestically owned firms.

Our results raise several issues for further research. To what extent can the results for Venezuela be extended to other developing countries? The level of foreign investment in Venezuela might be too low, or the economy not sufficiently developed or diversified, to receive large benefits from foreign presence. The scope for spillovers might be greater in the export-oriented economies in East Asia. ${ }^{12} \mathrm{We}$ also ignore other potential gains from foreign investment, such as increased employment and inflows of capital. Finally, we may fail to capture the long-run effects of DFI. If positive effects are permanent, while the negative effects are transitory, then as unprofitable firms exit, the negative productivity effects could decline. The productive advantage of foreign ownership might increase the stock of human capital if domestic workers absorb this advantage through training and learning-by-doing. Over long periods of time, this advantage might eventually spill over through labor mobility. However, we found little evidence that such spillovers occur within our sample.

\footnotetext{
${ }^{12}$ However, results for Indonesia suggest this is not the case. Estimating production functions on data from a census of Indonesian manufacturing firms for 1975-1989, we find results similar to those for Venezuela: productivity is higher in plants which receive foreign investment, but there is a negative spillover effect for domestically owned plants in the same industry. An interesting difference is that the positive effect is much larger than that estimated for Venezuela, and the negative effect is much smaller. We also find that the positive plant-level effect of foreign investment is quite large, but becomes insignificant in a first-difference or within specification, as reported in Table 1 for Venezuela.
}

\section{REFERENCES}

Aitken, Brian J. and Harrison, Ann E. "Do Domestic Firms Benefit from Foreign Direct Investment? Evidence from Panel Data." Mimeo, Columbia University, 1997.

-Blomstrom, Magnus. "Foreign Investment and Productive Efficiency: The Case of Mexico." Journal of Industrial Economics, September 1986, 35(1), pp. 97-110.

. Foreign investment and spillovers. London: Routledge, 1989.

Blomstrom, Magnus and Persson, Hakan. "Foreign Investment and Spillover Efficiency in an Underdeveloped Economy: Evidence from the Mexican Manufacturing Industry." World Development, June 1983, 11(6), pp. 493-501.

Blomstrom, Magnus and Wolff, Edward W. "Multinational Corporations and Productivity Convergence in Mexico." Mimeo, New York University, 1989.

Caves, Richard E. "International Corporations: The Industrial Economics of Foreign Investment." Economica, February 1971, 38(149), pp. 1-27.

. "Multinational Firms, Competition, and Productivity in Host-Country Markets."

-Economica, May 1974, 41(162), pp. 176-93. . Multinational enterprise and economic analysis. Cambridge: Cambridge University Press, 1982.

Dinardo, John; Johnston, Jack and Johnston, John. Econometric methods. New York: McGraw-Hill, October 1996.

Edfelt, Ralph B. "Direct Investment in a Developing Economy: Towards Evaluating the Human Resource Development Impact in Brazil." Ph.D. dissertation, University of California, Los Angeles, 1975.

Germidis, Dimitri. Transfer of technology by multinational corporations. Paris: Development Centre of the Organization for Economic Cooperation and Development, 1977.

Globerman, Steven. "Foreign Direct Investment and 'Spillover' Efficiency Benefits in Canadian Manufacturing Industries." Canadian Journal of Economics, February 1979, 12(1), pp. 42-56.

Goncalves, Reinaldo. "Technological Spillovers and Manpower Training: A Comparative Analysis of Multinational and National Enterprises in Brazilian Manufacturing." Jour- 
nal of Development Economics, July 1986, 11(1), pp. 119-32.

Grieco, Joseph M. "Foreign Investment and Development: Theories and Evidence," in Thodore H. Moran, ed., Investing in development: New roles for private capital? New Brunswick, NJ: Transaction Books, 1986, pp. 35-60.

Helleiner, Gerald K. "Transnational Corporations and Direct Foreign Investment," in Hollis Chenery and T. N. Srinivasan, eds., Handbook of development economics. Amsterdam: North-Holland, 1989.

-Helpman, Elhanan. "A Simple Theory of International Trade with Multinational Corporations." Journal of Political Economy, June 1984, 92(3), pp. 451-71.

Horstmann, Ignatius J. and Markusen, James R. "Firm-Specific Assets and the Gains from Direct Foreign Investment." Economica, February 1989, 56(221), pp. 41-48.

Hymer, Stephen. "The International Operations of National Firms: A Study of Direct Investment." Ph.D. dissertation, Massachusetts Institute of Technology, 1960.

Mansfied, Edwin and Romeo, Anthony. "Technology Transfer to Overseas Subsidiaries by
U.S.-Based Firms." Quarterly Journal of Economics, December 1980, 95(4), pp. 73750.

Matos, Luis. "Multinational Corporations and Transfer of Technology: The Case of Venezuela," in Dimitri Germidis, ed., Transfer of technology by multinational corporations. Paris: Development Centre of the Organization for Economic Cooperation and Development, 1977.

Rauch, James E. "Productivity Gains From Geographic Concentration of Human Capital: Evidence from the Cities." Mimeo, University of California, San Diego, 1991.

Rhee, Jong Wong and Belot, Therese. "Export Catalysts in Low-Income Countries." Working paper, World Bank, 1989.

Rugman, Alan M. "New Theories of the Multinational Enterprise: An Assessment of Internalization Theory." Bulletin of Economic Research, May 1986, 38(2), pp. 101-18.

- Teece, David J. “Technology Transfer by Multinational Firms: The Resource Cost of Transferring Technological Know-how." Economic Journal, June 1977, 87(346), pp. 242-61. 


\section{This article has been cited by:}

1. Mico Apostolov. 2016. Cobb-Douglas production function on FDI in Southeast Europe. Journal of Economic Structures 5. . [CrossRef]

2. Estefania Santacreu-Vasut, Kensuke Teshima. 2016. Foreign employees as channel for technology transfer: Evidence from MNC's subsidiaries in Mexico. Journal of Development Economics 122, 92-112. [CrossRef]

3. Cassandra C. Wang, Aiqi Wu. 2016. Geographical FDI knowledge spillover and innovation of indigenous firms in China. International Business Review 25:4, 895-906. [CrossRef]

4. Mario Levis, Yaz Gülnur Muradoǧlu, Kristina Vasileva. 2016. Home bias persistence in foreign direct investments. The European Journal of Finance 22:8-9, 782-802. [CrossRef]

5. Byung Il Park, Shufeng Simon Xiao. 2016. When Do Local Firms Benefit from Inward Foreign Direct Investment? A Longitudinal Study of China's Manufacturing Sector Covering 1998-2007. Thunderbird International Business Review 58:4, 331-345. [CrossRef]

6. Jaap W. B. Bos, Bertrand Candelon, Claire Economidou. 2016. Does knowledge spill over across borders and technology regimes?. Journal of Productivity Analysis . [CrossRef]

7. PAITOON WIBOONCHUTIKULA, CHAYANON PHUCHAROEN, NUCHIT PRUEKTANAKUL. 2016. SPILLOVER EFFECTS OF FOREIGN DIRECT INVESTMENT ON DOMESTIC MANUFACTURING FIRMS IN THAILAND. The Singapore Economic Review 1640028. [CrossRef]

8. Saul Estrin, Milica Uvalic. 2016. Foreign Direct Investment in the Western Balkans: What Role Has it Played During Transition?. Comparative Economic Studies . [CrossRef]

9. Keun Lee, Kineung Choo, Minho Yoon. 2016. Comparing the productivity impacts of knowledge spillovers from network and arm's length industries: findings from business groups in Korea. Industrial and Corporate Change 25:3, 407-427. [CrossRef]

10. Dic Lo, Fuhai Hong, Guicai Li. 2016. Assessing the role of inward foreign direct investment in Chinese economic development, 1990-2007: Towards a synthesis of alternative views. Structural Change and Economic Dynamics 37, 107-120. [CrossRef]

11. Nicos Christodoulakis, Vassilis Sarantides. 2016. External Asymmetries in the Euro Area and the Role of Foreign Direct Investment. The World Economy . [CrossRef]

12. Clement Kong Wing Chow, Michael Ka Yiu Fung, Japhet Sebastian LawRegional Development and Airport Productivity in China 283-316. [CrossRef]

13. Bethuel Kinyanjui Kinuthia. 2016. Technology spillovers: Kenya and Malaysia compared. The Journal of International Trade \& Economic Development 25, 536-569. [CrossRef]

14. Yuandi Wang, Lutao Ning, Jian Li, Martha Prevezer. 2016. Foreign Direct Investment Spillovers and the Geography of Innovation in Chinese Regions: The Role of Regional Industrial Specialization and Diversity. Regional Studies 50, 805-822. [CrossRef]

15. Lutao Ning, Fan Wang, Jian Li. 2016. Urban innovation, regional externalities of foreign direct investment and industrial agglomeration: Evidence from Chinese cities. Research Policy 45, 830-843. [CrossRef]

16. Cristina Jude, Monica Ioana Pop Silaghi. 2016. Employment effects of foreign direct investment: New evidence from Central and Eastern European countries. International Economics 145, 32-49. [CrossRef]

17. Mi Lin, Yum K. Kwan. 2016. FDI technology spillovers, geography, and spatial diffusion. International Review of Economics \& Finance 43, 257-274. [CrossRef] 
18. Stav Fainshmidt, Adam Smith, William Q. Judge. 2016. National Competitiveness and Porter's Diamond Model: The Role of MNE Penetration and Governance Quality. Global Strategy Journal 6:2, 81-104. [CrossRef]

19. Tran Toan Thang, Thi Song Hanh Pham, Bradley R. Barnes. 2016. Spatial Spillover Effects from Foreign Direct Investment in Vietnam. The Journal of Development Studies 1-15. [CrossRef]

20. Syeda Tamkeen Fatima. 2016. Productivity spillovers from foreign direct investment: evidence from Turkish micro-level data. The Journal of International Trade \& Economic Development 25, 291-324. [CrossRef]

21. William Sheng Liu, Frank Wogbe Agbola, Janet Ama Dzator. 2016. The impact of FDI spillover effects on total factor productivity in the Chinese electronic industry: a panel data analysis. Journal of the Asia Pacific Economy 21, 217-234. [CrossRef]

22. Denis Yongmin Joe, Frederick Dongchuhl Oh. 2016. DID FOREIGN OWNERSHIP OF KOREAN CREDIT RATING AGENCIES IMPROVE THEIR RATINGS?. Contemporary Economic Policy . [CrossRef]

23. Anabela Reis, Manuel Heitor, Miguel Amaral, Joana Mendonça. 2016. Revisiting industrial policy: Lessons learned from the establishment of an automotive OEM in Portugal. Technological Forecasting and Social Change . [CrossRef]

24. Veland Ramadani, Hyrije Abazi-Alili, Léo-Paul Dana, Gadaf Rexhepi, Sadudin Ibraimi. 2016. The impact of knowledge spillovers and innovation on firm-performance: findings from the Balkans countries. International Entrepreneurship and Management Journal . [CrossRef]

25. Pierre Blanchard, Claude Mathieu. 2016. Multinationals and domestic firms in France: who gains from knowledge spillovers?. Review of Agricultural, Food and Environmental Studies . [CrossRef]

26. Meltem Ucal, Alfred Albert Haug, Mehmet Hüseyin Bilgin. 2016. Income inequality and FDI: evidence with Turkish data. Applied Economics 48, 1030-1045. [CrossRef]

27. Puan Yatim, Takiah Mohd Iskandar, Elsie Nga. 2016. Board attributes and foreign shareholdings in Malaysian listed firms. Journal of Management \& Governance 20, 147-178. [CrossRef]

28. Binyam A. Demena, Peter A. G. van Bergeijk. 2016. A META-ANALYSIS OF FDI AND PRODUCTIVITY SPILLOVERS IN DEVELOPING COUNTRIES. Journal of Economic Surveys n/a-n/a. [CrossRef]

29. Petr Pavlínek, Pavla Žižalová. 2016. Linkages and spillovers in global production networks: firm-level analysis of the Czech automotive industry. Journal of Economic Geography 16, 331-363. [CrossRef]

30. Rosa Portela Forte. 2016. Multinational firms and host country market structure: A review of empirical literature. The Journal of International Trade \& Economic Development 25, 240-265. [CrossRef]

31. Qiang (Steven) Lu, Chinmay Pattnaik, Mengze Shi. 2016. Spillover effects of marketing expertise on market performance of domestic firms and MNEs in emerging markets. Management Decision 54, 107-129. [CrossRef]

32. Peter J. Buckley, Surender Munjal, Peter Enderwick, Nicolas Forsans. 2016. Do foreign resources assist or impede internationalisation? Evidence from internationalisation of Indian multinational enterprises. International Business Review 25, 130-140. [CrossRef]

33. Roger Smeets, Albert de Vaal. 2016. Intellectual Property Rights and the productivity effects of MNE affiliates on host-country firms. International Business Review 25, 419-434. [CrossRef]

34. Neil Foster-McGregor, Anders Isaksson, Florian Kaulich. 2016. Importing, Productivity and Absorptive Capacity in Sub-Saharan African Manufacturing and Services Firms. Open Economies Review 27, 87-117. [CrossRef]

35. Firat Demir, Li Su. 2016. Total Factor Productivity, Foreign Direct Investment, and Entry Barriers in the Chinese Automotive Industry. Emerging Markets Finance and Trade 52, 302-321. [CrossRef] 
36. Marco Sanfilippo, Adnan Seric. 2016. Spillovers from agglomerations and inward FDI: a multilevel analysis on sub-Saharan African firms. Review of World Economics 152, 147-176. [CrossRef]

37. Junjie Hong, Xiaonan Sun, Wei Huang. 2016. Local Institutions, Foreign Direct Investment and Productivity of Domestic Firms. Review of Development Economics 20:10.1111/rode.2016.20.issue-1, 25-38. [CrossRef]

38. Jens Matthias Arnold, Beata Javorcik, Molly Lipscomb, Aaditya Mattoo. 2016. Services Reform and Manufacturing Performance: Evidence from India. The Economic Journal 126:10.1111/ ecoj.2016.126.issue-590, 1-39. [CrossRef]

39. Shujing Yue, Yang Yang, Yaoyu Hu. 2016. Does Foreign Direct Investment Affect Green Growth? Evidence from China's Experience. Sustainability 8, 158. [CrossRef]

40. Elikplimi Komla Agbloyor, Agyapomaa Gyeke-Dako, Ransome Kuipo, Joshua Yindenaba Abor. 2016. Foreign Direct Investment and Economic Growth in SSA: The Role of Institutions. Thunderbird International Business Review n/a-n/a. [CrossRef]

41. Tilo F. Halaszovich, Sarianna M. Lundan. 2016. The moderating role of local embeddedness on the performance of foreign and domestic firms in emerging markets. International Business Review . [CrossRef]

42. Tin Htoo Naing, Su-Fei Yap. 2016. Multinationals, technology and regional linkages in Myanmar's clothing industry. Asia Pacific Business Review 22, 131-149. [CrossRef]

43. Sunil Kumar Ambrammal, Ruchi Sharma. 2016. Impact of patenting on firms' performance: an empirical investigation based on manufacturing firms in India. Economics of Innovation and New Technology 25, 14-32. [CrossRef]

44. Agnieszka Gehringer. 2016. Knowledge externalities and sectoral interdependences: Evidence from an open economy perspective. Technological Forecasting and Social Change 102, 240-249. [CrossRef]

45. Wei Jin. 2016. International technology diffusion, multilateral R\&D coordination, and global climate mitigation. Technological Forecasting and Social Change 102, 357-372. [CrossRef]

46. Alessandra Perri, Enzo Peruffo. 2016. Knowledge Spillovers from FDI: A Critical Review from the International Business Perspective. International Journal of Management Reviews 18:10.1111/ ijmr.2016.18.issue-1, 3-27. [CrossRef]

47. Xiaolong Zhang. 2016. Export Mode Heterogenicity and Enterprise Productivity-A Test about Learning by Exporting. Modern Economy 07, 84-91. [CrossRef]

48. Byeongwoo Kang. 2016. What best transfers knowledge? Capital, goods, and labor in East Asia. Economics Letters . [CrossRef]

49. Aneta Bobenič Hintošová, Zuzana Kubíková. 2016. The effect of the degree of foreign ownership on firms' performance. Review of Economic Perspectives 16. . [CrossRef]

50. Mico Apostolov. 2016. Foreign Direct Investments Induced Innovation? A Case Study - Macedonia. Comparative Economic Research 19:1. . [CrossRef]

51. Maitri GhoshMNEs and Export Spillovers: A Firm-Level Analysis of Indian Manufacturing Industries 33-48. [CrossRef]

52. Basabi Bhattacharya, Jaydeep MukherjeeForeign Direct Investment and Macroeconomic Indicators in India: A Causality Analysis 373-384. [CrossRef]

53. Yiqun Ma. 2015. Uncertainty and investment: Evidence from the Australian mining industry. Resources Policy 46, 191-201. [CrossRef]

54. Chul-Woo Kwon, Bong Geul Chun. 2015. The effect of strategic technology adoptions by local firms on technology spillover. Economic Modelling 51, 13-20. [CrossRef] 
55. Harald Badinger, Peter Egger. 2015. Productivity Spillovers Across Countries and Industries: New Evidence From OECD Countries. Oxford Bulletin of Economics and Statistics n/a-n/a. [CrossRef]

56. Mico Apostolov. 2015. Effects of foreign direct investments. Evidence from Southeast Europe. Cuadernos de Economía . [CrossRef]

57. Jian Wang, Xiao Wang. 2015. Benefits of foreign ownership: Evidence from foreign direct investment in China. Journal of International Economics 97, 325-338. [CrossRef]

58. Monica Singhania, Neha Saini, Puneet Gupta. 2015. Foreign Ownership and Indian Firm Performance: A Dynamic Panel Approach. The Journal of Private Equity 19, 77-85. [CrossRef]

59. Jingmei Ma, Hongyu Jia. 2015. The Role of Foreign Direct Investment on Income Convergence in China after Early 1990s from a Spatial Econometric Perspective. Review of Development Economics 19:10.1111/rode.2015.19.issue-4, 829-842. [CrossRef]

60. Cristina Jude. 2015. Technology Spillovers from FDI. Evidence on the Intensity of Different Spillover Channels. The World Economy n/a-n/a. [CrossRef]

61. Sergio Mariotti, Marco Mutinelli, Marcella Nicolini, Lucia Piscitello. 2015. Productivity Spillovers from Foreign Multinational Enterprises to Domestic Manufacturing Firms: To What Extent Does Spatial Proximity Matter?. Regional Studies 49, 1639-1653. [CrossRef]

62. Korbinian Nagel, Dierk Herzer, Peter Nunnenkamp. 2015. How Does FDI Affect Health?. International Economic Journal 29, 655-679. [CrossRef]

63. Neil Foster-McGregor, Anders Isaksson, Florian Kaulich. 2015. Foreign Ownership and Performance in Sub-Saharan African Manufacturing and Services. Journal of International Development 27:10.1002/ jid.v27.7, 1197-1222. [CrossRef]

64. Karolien Lenaerts, Bruno Merlevede. 2015. Firm size and spillover effects from foreign direct investment: the case of Romania. Small Business Economics 45, 595-611. [CrossRef]

65. Steve Loris Gui-Diby, Mary-Françoise Renard. 2015. Foreign Direct Investment Inflows and the Industrialization of African Countries. World Development 74, 43-57. [CrossRef]

66. Ali Salim, Mohammad Reza Razavi, Masoud Afshari-Mofrad. 2015. Foreign direct investment and technology spillover in Iran: The role of technological Capabilities of subsidiaries. Technological Forecasting and Social Change . [CrossRef]

67. Andrew Watkins, Theo Papaioannou, Julius Mugwagwa, Dinar Kale. 2015. National innovation systems and the intermediary role of industry associations in building institutional capacities for innovation in developing countries: A critical review of the literature. Research Policy 44:8, 1407-1418. [CrossRef]

68. Sabina Silajdzic, Eldin Mehic. 2015. Absorptive Capabilities, FDI, and Economic Growth in Transition Economies. Emerging Markets Finance and Trade 1-19. [CrossRef]

69. Canan C. Mutlu, Wu Zhan, Mike W. Peng, Zhiang Lin. 2015. Competing in (and out of) transition economies. Asia Pacific Journal of Management 32, 571-596. [CrossRef]

70. Ayesha Ashraf, Dierk Herzer, Peter Nunnenkamp. 2015. The Effects of Greenfield FDI and Crossborder M\&As on Total Factor Productivity. The World Economy n/a-n/a. [CrossRef]

71. C. Fritz Foley, Kalina Manova. 2015. International Trade, Multinational Activity, and Corporate Finance. Annual Review of Economics 7, 119-146. [CrossRef]

72. Yoo Jung Ha, Axèle Giroud. 2015. Competence-creating subsidiaries and FDI technology spillovers. International Business Review 24, 605-614. [CrossRef]

73. Angelo Antoci, Simone Borghesi, Paolo Russu, Elisa Ticci. 2015. Foreign direct investments, environmental externalities and capital segmentation in a rural economy. Ecological Economics 116, 341-353. [CrossRef] 
74. Agnieszka Gehringer, Inmaculada Martínez-Zarzoso, Felicitas Nowak-Lehmann Danzinger. 2015. What are the drivers of total factor productivity in the European Union?. Economics of Innovation and New Technology 1-29. [CrossRef]

75. Zaheer Khan, Yong Kyu Lew, Rudolf R. Sinkovics. 2015. The mirage of upgrading local automotive parts suppliers through the creation of vertical linkages with MNEs in developing economies. Critical perspectives on international business 11, 301-318. [CrossRef]

76. Wei Jin. 2015. Can China harness globalization to reap domestic carbon savings? Modeling international technology diffusion in a multi-region framework. China Economic Review 34, 64-82. [CrossRef]

77. Azusa Fujimori, Takahiro Sato. 2015. Productivity and technology diffusion in India: The spillover effects from foreign direct investment. Journal of Policy Modeling 37, 630-651. [CrossRef]

78. Ying Ge, Huiwen Lai, Susan Chun Zhu. 2015. Multinational price premium. Journal of Development Economics 115, 181-199. [CrossRef]

79. Fukunari Kimura, Tomohiro Machikita, Yasushi Ueki. 2015. Technology transfer in ASEAN countries: some evidence from buyer-provided training network data. Economic Change and Restructuring . [CrossRef]

80. Jan Hanousek, Evžen Kočenda, Anastasiya Shamshur. 2015. Corporate efficiency in Europe. Journal of Corporate Finance 32, 24-40. [CrossRef]

81. Mario Kafouros, Elizabeth Yi Wang. 2015. Technology transfer within China and the role of location choices. International Business Review 24, 353-366. [CrossRef]

82. Badi H. Baltagi, Peter H. Egger, Michaela Kesina. 2015. Sources of productivity spillovers: panel data evidence from China. Journal of Productivity Analysis 43, 389-402. [CrossRef]

83. Rosanna Pittiglio, Filippo Reganati, Edgardo Sica. 2015. Do Multinational Enterprises Push up the Wages of Domestic Firms in the Italian Manufacturing Sector?*. The Manchester School 83:10.1111/ manc.2015.83.issue-3, 346-378. [CrossRef]

84. Adriana Peluffo. 2015. Foreign Direct Investment, Productivity, Demand for Skilled Labour and Wage Inequality: An Analysis of Uruguay. The World Economy 38:10.1111/twec.2015.38.issue-6, 962-983. [CrossRef]

85. Natalya Smith, Ekaterina Thomas. 2015. The Role of Foreign Direct Investment and State Capture in Shaping Innovation Outcome in Russia. Europe-Asia Studies 67, 777-808. [CrossRef]

86. Saurav Pathak, André Laplume, Emanuel Xavier-Oliveira. 2015. Inbound foreign direct investment and domestic entrepreneurial activity. Entrepreneurship \& Regional Development 27, 334-356. [CrossRef]

87. Tinh Doan, David Maré, Kris Iyer. 2015. Productivity spillovers from foreign direct investment in New Zealand. New Zealand Economic Papers 1-27. [CrossRef]

88. Augusto de la Torre, Tatiana Didier, Alain Ize, Daniel Lederman, Sergio L. SchmuklerThe Changing Patterns of Financial Integration in Latin America and the Caribbean 153-196. [CrossRef]

89. Reza Ghazal, Muhamed Zulkhibri. 2015. Determinants of innovation outputs in developing countries. Journal of Economic Studies 42, 237-260. [CrossRef]

90. Alireza Naghavi, Chiara Strozzi. 2015. Intellectual property rights, diasporas, and domestic innovation. Journal of International Economics 96, 150-161. [CrossRef]

91. Chunlai Chen. 2015. Do Inland Provinces Benefit from Coastal Foreign Direct Investment in China?. China \& World Economy 23:10.1111/cwe.2015.23.issue-3, 22-41. [CrossRef]

92. Noor Aini Khalifah, Salmah Mohd Salleh, Radziah Adam. 2015. FDI productivity spillovers and the technology gap in Malaysia's electrical and electronic industries. Asian-Pacific Economic Literature 29:10.1111/apel.2015.29.issue-1, 142-160. [CrossRef] 
93. Carol Newman, John Rand, Theodore Talbot, Finn Tarp. 2015. Technology transfers, foreign investment and productivity spillovers. European Economic Review 76, 168-187. [CrossRef]

94. Junmo Kim, Hyuk-Dong Kwon, Youngkwan Kwon. 2015. Effect of ODA on the Donor's Economy: Localization and Technological Innovation Efforts of Recipient Country and the Sectoral Differentials of Effects. Asian Journal of Innovation and Policy 4, 1-18. [CrossRef]

95. Sorin M.S. Krammer. 2015. Do good institutions enhance the effect of technological spillovers on productivity? Comparative evidence from developed and transition economies. Technological Forecasting and Social Change 94, 133-154. [CrossRef]

96. Xuemei Jiang, Kunfu Zhu, Christopher Green. 2015. China's energy saving potential from the perspective of energy efficiency advantages of foreign-invested enterprises. Energy Economics 49, 104-112. [CrossRef]

97. Natalya Smith, Ekaterina Thomas. 2015. Determinants of Russia's Informal Economy: The Impact of Corruption and Multinational Firms. Journal of East-West Business 21, 102-128. [CrossRef]

98. Riccardo Crescenzi, Luisa Gagliardi, Simona Iammarino. 2015. Foreign multinationals and domestic innovation: Intra-industry effects and firm heterogeneity. Research Policy 44, 596-609. [CrossRef]

99. Sourafel Girma, Yundan Gong, Holger Görg, Sandra Lancheros. 2015. Investment liberalisation, technology take-off and export markets entry: Does foreign ownership structure matter?. Journal of Economic Behavior \& Organization . [CrossRef]

100. Mebratu Seyoum, Renshui Wu, Li Yang. 2015. Technology spillovers from Chinese outward direct investment: The case of Ethiopia. China Economic Review 33, 35-49. [CrossRef]

101. Ahmad Zubaidi Baharumshah, Ly Slesman, Evelyn Shyamala Devadason. 2015. Types of Foreign Capital Inflows and Economic Growth: New Evidence on Role of Financial Markets. Journal of International Development $\mathrm{n} / \mathrm{a}-\mathrm{n} / \mathrm{a}$. [CrossRef]

102. Michael Hübler. 2015. A theory-based discussion of international technology funding. Environmental Economics and Policy Studies 17, 313-327. [CrossRef]

103. Sanjaya Kumar Malik. 2015. Conditional technology spillovers from foreign direct investment: evidence from Indian manufacturing industries. Journal of Productivity Analysis 43, 183-198. [CrossRef]

104. Minjung Kim. 2015. Productivity spillovers from FDI and the role of domestic firm's absorptive capacity in South Korean manufacturing industries. Empirical Economics 48, 807-827. [CrossRef]

105. Mahmut Yaşar. 2015. Direct and Indirect Exporting and Productivity: Evidence from Firm-Level Data. Managerial and Decision Economics 36:10.1002/mde.v36.2, 109-120. [CrossRef]

106. Jingtao Yi, Yan Chen, Chengqi Wang, Mario Kafouros. 2015. Spillover Effects of Foreign Direct Investment: How do Region-Specific Institutions Matter?. Management International Review . [CrossRef]

107. Yan Chen, Rui-Rui Zhai, Chengqi Wang, Changbiao Zhong. 2015. Home institutions, internationalization and firm performance. Management Decision 53, 160-178. [CrossRef]

108. Hyuk-Hwang Kim, Hongshik Lee, Joonhyung Lee. 2015. Technology diffusion and host-country productivity in South-South FDI flows. Japan and the World Economy 33, 1-10. [CrossRef]

109. B. S. Javorcik. 2015. Does FDI Bring Good Jobs to Host Countries?. The World Bank Research Observer 30, 74-94. [CrossRef]

110. Jacopo Torriti, Eka Ikpe. 2015. Administrative costs of regulation and foreign direct investment: the Standard Cost Model in non-OECD countries. Review of World Economics 151, 127-144. [CrossRef]

111. Cheryl Long, Jin Yang, Jing Zhang. 2015. Institutional Impact of Foreign Direct Investment in China. World Development 66, 31-48. [CrossRef] 
112. Bukhari M. S. Sillah. 2015. Human capital, foreign direct investment stock, trade and the technology diffusion in Saudi Arabia 1974-2011. Journal of Economic Studies 42, 101-116. [CrossRef]

113. References 337-340. [CrossRef]

114. Rosanna Pittiglio, Filippo Reganati. 2015. Multinational Enterprises, Technological Intensity and Firm Survival. Evidence from Italian Manufacturing and Services Firms. Atlantic Economic Journal 43:1, 87. [CrossRef]

115. Tomohiro Machikita, Yasushi Ueki. 2015. Measuring and Explaining Innovative Capability: Evidence from Southeast Asia. Asian Economic Policy Review 10:10.1111/aepr.2015.10.issue-1, 152-173. [CrossRef]

116. Backhoon Song. 2015. Location Proximity and Productivity Spillovers: The Case of Korean Manufacturing Plants *. Asian Economic Papers 14, 104-118. [CrossRef]

117. Michael Jakob, Jan Christoph Steckel, Christian Flachsland, Lavinia Baumstark. 2015. Climate finance for developing country mitigation: blessing or curse?. Climate and Development 7, 1-15. [CrossRef]

118. Mi Lin, Yum K. Kwan. 2015. FDI Spatial Spillovers in China. The World Economy n/a. [CrossRef]

119. Gil Kim, Lian An, Yoonbai Kim. 2015. Exchange Rate, Capital Flow and Output: Developed versus Developing Economies. Atlantic Economic Journal 43:2, 195. [CrossRef]

120. Sahraoui Mohammed Abbes, Belmokaddem Mostéfa, GuellilMohammed Seghir, Ghouali Yassine Zakarya. 2015. Causal Interactions between FDI, and Economic Growth: Evidence from Dynamic Panel Co-integration. Procedia Economics and Finance 23, 276-290. [CrossRef]

121. Hiau Looi Kee. 2015. Local intermediate inputs and the shared supplier spillovers of foreign direct investment. Journal of Development Economics 112, 56-71. [CrossRef]

122. Thi Ngoc Thuyen Truong, Juthathip Jongwanich, Eric D. Ramstetter. 2015. Productivity spillovers from foreign multinationals and trade protection: firm-level analysis of Vietnamese manufacturing. Asian-Pacific Economic Literature 29:2, 30. [CrossRef]

123. Albert Guangzhou Hu. 2015. Innovation and Economic Growth in East Asia: An Overview. Asian Economic Policy Review 10:10.1111/aepr.2015.10.issue-1, 19-37. [CrossRef]

124. Khaled Elmawazini. 2015. Foreign affiliates, technological catch-up, and productivity growth: Evidence from MENA oil and non-oil-producing countries. The Journal of High Technology Management Research 26, 117-123. [CrossRef]

125. Reinhilde Veugelers, Helena Schweiger. 2015. Innovation policies in transition countries: one size fits all?. Economic Change and Restructuring . [CrossRef]

126. Roberto Antonietti, Raffaello Bronzini, Giulio Cainelli. 2015. Inward greenfield FDI and innovation. Economia e Politica Industriale 42:1, 93. [CrossRef]

127. Sourafel Girma, Yundan Gong, Holger Görg, Sandra Lancheros. 2015. Estimating direct and indirect effects of foreign direct investment on firm productivity in the presence of interactions between firms. Journal of International Economics 95, 157-169. [CrossRef]

128. China Flora Carine Anguibi. 2015. An Investigation of the Long-Run and Causal Relationships between Economy Performance, Investment and Port Sector Productivity in Cote d'Ivoire. Open Journal of Social Sciences 03, 29-38. [CrossRef]

129. Hongyan Yang, Ting Ren, Massimiliano SassoneForeign Direct Investment, Institutional Environment, and the Establishment of Private Economy in China 107-132. [CrossRef]

130. Natalya Smith, Ekaterina ThomasInnovation in Emerging Economies: The Spillover Effects of Foreign Direct Investment and Institutions in Russia 146-172. [CrossRef] 
131. Ziko Konwar, Frank McDonald, Chengang Wang, Yingqi WeiDo Foreign Ownership Modes Matter for FDI Spillovers? 243-261. [CrossRef]

132. K. Farla. 2014. Determinants of firms' investment behaviour: a multilevel approach. Applied Economics 46, 4231-4241. [CrossRef]

133. Khaled Elmawazini. 2014. FDI Spillovers, Efficiency Change and Host Country Labor Productivity: Evidence from GCC Countries. Atlantic Economic Journal 42, 399-411. [CrossRef]

134. Yang Yang, Xiaohua Yang, Rongxin (Roger) Chen, Jonathan P Allen. 2014. What drives emergingeconomy outbound FDI decisions to obtain strategic assets?. Asian Business \& Management 13, 379-410. [CrossRef]

135. Anna M. Ferragina, Fernanda Mazzotta. 2014. FDI spillovers on firm survival in Italy: absorptive capacity matters!. The Journal of Technology Transfer 39, 859-897. [CrossRef]

136. Luosha Du, Ann Harrison, Gary Jefferson. 2014. FDI Spillovers and Industrial Policy: The Role of Tariffs and Tax Holidays. World Development 64, 366-383. [CrossRef]

137. Yuriy Gorodnichenko, Jan Svejnar, Katherine Terrell. 2014. When does FDI have positive spillovers? Evidence from 17 transition market economies. Journal of Comparative Economics 42, 954-969. [CrossRef]

138. Facundo Albornoz, Matthew A. Cole, Robert J.R. Elliott, Marco G. Ercolani. 2014. The environmental actions of firms: Examining the role of spillovers, networks and absorptive capacity. Journal of Environmental Management 146, 150-163. [CrossRef]

139. Wasseem Mina. 2014. United Arab Emirates FDI Outlook. The World Economy 37:10.1111/ twec.2014.37.issue-12, 1716-1730. [CrossRef]

140. Elif Kalayc1, Teoman Pamukçu. 2014. Assessing the Drivers of R\&D Activities of Firms in Developing Countries: Evidence From Turkey. The European Journal of Development Research 26:5, 853-869. [CrossRef]

141. Natasha Agarwal, Chris Milner, Alejandro Riaño. 2014. Credit constraints and spillovers from foreign firms in China. Journal of Banking \& Finance 48, 261-275. [CrossRef]

142. Andrzej Cieślik, Jan Hagemejer. 2014. Multinational Enterprises, Absorptive Capacity and Export Spillovers: Evidence from Polish Firm-level Data. Review of Development Economics 18:10.1111/ rode.2014.18.issue-4, 709-726. [CrossRef]

143. David Sondermann. 2014. Productivity in the euro area: any evidence of convergence?. Empirical Economics 47, 999-1027. [CrossRef]

144. Natalya Smith, Ekaterina Thomas, Christos AntoniouMulti-National Firms, Corruption and Innovation in Russia 347-371. [CrossRef]

145. Iliana Olivié, Aitor Pérez. 2014. How to deal with the "black box" of foreign investment and development? A case study in the Dominican Republic and a methodological proposal. Canadian Journal of Development Studies / Revue canadienne d'études du développement 35, 539-559. [CrossRef]

146. Ellis L.C. Osabutey, Karen Williams, Yaw A. Debrah. 2014. The potential for technology and knowledge transfers between foreign and local firms: A study of the construction industry in Ghana. Journal of World Business 49, 560-571. [CrossRef]

147. Sasatra Sudsawasd, Santi Chaisrisawatsuk. 2014. Foreign Direct Investment, Intellectual Property Rights, and Productivity Growth. Journal of International Commerce, Economics and Policy 05, 1440009. [CrossRef]

148. Yi Zhang, Hein Roelfsema. 2014. Globalization, Foreign Direct Investment, and Regional Innovation in China. Journal of International Commerce, Economics and Policy 05, 1440007. [CrossRef] 
149. Thomas Hutzschenreuter, Ingo Kleindienst, Florian Groene, Alain Verbeke. 2014. Corporate strategic responses to foreign entry: insights from prospect theory. Multinational Business Review 22, 294-323. [CrossRef]

150. David Greenaway, Alessandra Guariglia, Zhihong Yu. 2014. The more the better? Foreign ownership and corporate performance in China. The European Journal of Finance 20, 681-702. [CrossRef]

151. Geoffrey G. Gachino. 2014. Foreign Investment and Technological Spillovers in Kenya: Extent and Mode of Occurrence. South African Journal of Economics 82:10.1111/saje.2014.82.issue-3, 422-442. [CrossRef]

152. Zeb Aurangzeb, Thanasis Stengos. 2014. The role of Foreign Direct Investment (FDI) in a dualistic growth framework: A smooth coefficient semi-parametric approach. Borsa Istanbul Review 14, 133-144. [CrossRef]

153. Hernán Herrera-Echeverri, Jerry Haar, Juan Benavides Estévez-Bretón. 2014. Foreign direct investment, institutional quality, economic freedom and entrepreneurship in emerging markets. Journal of Business Research 67, 1921-1932. [CrossRef]

154. Zeyong Tian, Tao LuThe threshold effect between technology gaps based on the heterogeneity 339-344. [CrossRef]

155. Chiara Franco, John P. Weche Gelübcke. 2014. The Death of German Firms: What Role for Foreign Direct Investment?. The World Economy n/a-n/a. [CrossRef]

156. Tsu-Lung Chou, Jung-Ying Chang, Te-Chuan Li. 2014. Government Support, FDI Clustering and Semiconductor Sustainability in China: Case Studies of Shanghai, Suzhou and Wuxi in the Yangtze Delta. Sustainability 6, 5655-5681. [CrossRef]

157. Nadide Sevil Tülüce, İbrahim Doğan. 2014. The Impact of Foreign Direct Investments on SMEs' Development. Procedia - Social and Behavioral Sciences 150, 107-115. [CrossRef]

158. JaeBin Ahn. 2014. A welfare analysis of unilateral trade and FDI liberalization. Canadian Journal of Economics/Revue canadienne d'économique 47:10.1111/caje.2014.47.issue-3, 758-774. [CrossRef]

159. Sajid Anwar, Sizhong Sun. 2014. Heterogeneity and curvilinearity of FDI-related productivity spillovers in China's manufacturing sector. Economic Modelling 41, 23-32. [CrossRef]

160. Satomi Kimino, Nigel Driffield, David Saal. 2014. Spillovers from FDI and local networks. Multinational Business Review 22, 176-193. [CrossRef]

161. Mohamed Saadi. 2014. Does foreign direct investment increase exports' productivity? Evidence from developing and emerging countries. International Review of Applied Economics 28, 482-506. [CrossRef]

162. Lin Chen, Changyuan Luo. 2014. FDI, market signal and financing constraints of firms in China. The Journal of International Trade \& Economic Development 23, 579-599. [CrossRef]

163. Keisuke Okada, Sovannroeun Samreth. 2014. How Does Corruption Influence the Effect of Foreign Direct Investment on Economic Growth?. Global Economic Review 43, 207-220. [CrossRef]

164. Amelia U. Santos-Paulino, Mariagrazia Squicciarini, Peilei Fan. 2014. Foreign Direct Investment, R\&D Mobility and the New Economic Geography: A Survey. The World Economy n/a-n/a. [CrossRef]

165. Bijun Wang, Rui Mao, Qin Gou. 2014. Overseas Impacts of China's Outward Direct Investment. Asian Economic Policy Review 9:10.1111/aepr.2014.9.issue-2, 227-249. [CrossRef]

166. Csilla Lakatos, Tani Fukui. 2014. The Liberalization of Retail Services in India. World Development 59, 327-340. [CrossRef]

167. Birgül Cambazoglu, Hacer Simay Karaalp. 2014. Does foreign direct investment affect economic growth? The case of Turkey. International Journal of Social Economics 41, 434-449. [CrossRef] 
168. Qing Liu, Ruosi Lu, Chao Zhang. 2014. Entrepreneurship and spillovers from multinationals: Evidence from Chinese private firms. China Economic Review 29, 95-106. [CrossRef]

169. Timo Mitze, Selin Özyurt. 2014. The Spatial Dimension of Trade- and FDI-driven Productivity Growth in Chinese Provinces: A Global Cointegration Approach. Growth and Change 45:10.1111/ grow.2014.45.issue-2, 263-291. [CrossRef]

170. Tetsushi Sonobe, Yuki Higuchi, Keijiro Otsuka. 2014. Differences in Management Practices and Productivity in Micro and Small Enterprises in Industrial Clusters. Journal of International Commerce, Economics and Policy 05, 1450006. [CrossRef]

171. In Hyeock Lee, Eunsuk Hong, Laixiang Sun. 2014. Inward Foreign Direct Investment and Domestic Entrepreneurship: A Regional Analysis of New Firm Creation in Korea. Regional Studies 48, 910-922. [CrossRef]

172. Farrokh Nourzad, David N. Greenwold, Rui Yang. 2014. The Interaction Between FDI and Infrastructure Capital in The Development Process. International Advances in Economic Research 20, 203-212. [CrossRef]

173. Pedro Sánchez-Sellero, Jorge Rosell-Martínez, José Manuel García-Vázquez. 2014. Spillovers from Foreign Direct Investment in Spanish Manufacturing Firms. Review of International Economics 22:10.1111/roie.2014.22.issue-2, 342-351. [CrossRef]

174. Aurora A.C. Teixeira, Ana Teresa Tavares-Lehmann. 2014. Human capital intensity in technologybased firms located in Portugal: Does foreign ownership matter?. Research Policy 43, 737-748. [CrossRef]

175. Qun Bao, Min Shao, Ligang Song. 2014. Is Export Spillover Localized in China. Review of Development Economics 18:10.1111/rode.2014.18.issue-2, 218-230. [CrossRef]

176. Michael Hübler, Alexander Glas. 2014. The Energy-Bias of North-South Technology Spillovers: A Global, Bilateral, Bisectoral Trade Analysis. Environmental and Resource Economics 58, 59-89. [CrossRef]

177. Z. Liu. 2014. Human capital externalities in cities: evidence from Chinese manufacturing firms. Journal of Economic Geography 14, 621-649. [CrossRef]

178. Joseph A Clougherty, Klaus Gugler, Lars Sørgard, Florian W Szücs. 2014. Cross-border mergers and domestic-firm wages: Integrating "spillover effects" and "bargaining effects". Journal of International Business Studies 45:4, 450-470. [CrossRef]

179. Jian Zhang, Ilan Alon, Yanan Chen. 2014. Does Chinese investment affect Sub-Saharan African growth?. International Journal of Emerging Markets 9, 257-275. [CrossRef]

180. Ayesha Ashraf, Dierk Herzer. 2014. The effects of greenfield investment and M\&As on domestic investment in developing countries. Applied Economics Letters 1-4. [CrossRef]

181. Leopoldo Laborda Castillo, Daniel Sotelsek Salem, Justo de Jorge Moreno. 2014. Foreign Direct Investment and Productivity Spillovers: Firm-Level Evidence From Chilean Industrial Sector. Latin American Business Review 15, 93-122. [CrossRef]

182. Joel Rodrigue. 2014. Multinational production, exports and aggregate productivity. Review of Economic Dynamics 17, 243-261. [CrossRef]

183. Bruno Merlevede, Koen Schoors, Mariana Spatareanu. 2014. FDI Spillovers and Time since Foreign Entry. World Development 56, 108-126. [CrossRef]

184. Hak-Seon Lee. 2014. Outward Foreign Direct Investment, Interindustry Networks, and U.S. Trade Politics. The International Trade Journal 28, 140-168. [CrossRef]

185. E. Giuliani, C. Macchi. 2014. Multinational corporations' economic and human rights impacts on developing countries: a review and research agenda. Cambridge Journal of Economics 38, 479-517. [CrossRef] 
186. Ari Kokko, Tran Toan Thang. 2014. Foreign Direct Investment and the Survival of Domestic Private Firms in Viet Nam. Asian Development Review 31, 53-91. [CrossRef]

187. Vasthiyampillai Sivalogathasan, Xiaobo Wu. 2014. The Effect of Foreign Direct Investment on Innovation in South Asian Emerging Markets. Global Business and Organizational Excellence 33:10.1002/joe.v33.3, 63-76. [CrossRef]

188. MICHELLE L. WASHINGTON, ZANETA CHAPMAN. 2014. ENTREPRENEURIAL ACTIVITY AS AN EXTERNALITY OF INWARD FOREIGN DIRECT INVESTMENT IN EMERGING ECONOMIES: PANEL DATA FROM ARGENTINA, BRAZIL, COLOMBIA AND SOUTH AFRICA. Journal of Developmental Entrepreneurship 19, 1450004. [CrossRef]

189. Botirjan Baltabaev. 2014. Foreign Direct Investment and Total Factor Productivity Growth: New Macro-Evidence. The World Economy 37:10.1111/twec.2014.37.issue-2, 311-334. [CrossRef]

190. Stefanie A. Haller. 2014. Do Domestic Firms Benefit from Foreign Presence and Import Competition in Irish Services Sectors?. The World Economy 37:10.1111/twec.2014.37.issue-2, 219-243. [CrossRef]

191. Cheng Zhang, Bingnan Guo, Jianke Wang. 2014. The different impacts of home countries characteristics in FDI on Chinese spillover effects: Based on one-stage SFA. Economic Modelling 38, 572-580. [CrossRef]

192. Rob van Tulder, Andrea da RosaMultinationals and Small- and Medium-Sized Enterprises (SMEs): A linkages perspective on inclusive development strategies 203-227. [CrossRef]

193. Gary H. Jefferson, Miao Ouyang. 2014. FDI spillovers in China: why do the research findings differ so much?. Journal of Chinese Economic and Business Studies 12, 1-27. [CrossRef]

194. Ralf Barkemeyer, Diane Holt, Lutz Preuss, Stephen Tsang. 2014. What Happened to the 'Development' in Sustainable Development? Business Guidelines Two Decades After Brundtland. Sustainable Development 22:10.1002/sd.v22.1, 15-32. [CrossRef]

195. Shandre M. Thangavelu, Dionisius Narjoko. 2014. Human capital, FTAs and foreign direct investment flows into ASEAN. Journal of Asian Economics 35, 65. [CrossRef]

196. Angus C. Chu, Guido Cozzi, Silvia Galli. 2014. Stage-dependent intellectual property rights. Journal of Development Economics 106, 239-249. [CrossRef]

197. Chiara F. Del Bo. 2014. Foreign and Spatial Spillovers in the European Electricity Sector. Symphonya. Emerging Issues in Management . [CrossRef]

198. Suyanto, Ruhul Salim, Harry Bloch. 2014. Which firms benefit from foreign direct investment? Empirical evidence from Indonesian manufacturing. Journal of Asian Economics 33, 16. [CrossRef]

199. Sorin M.S. Krammer. 2014. Assessing the relative importance of multiple channels for embodied and disembodied technological spillovers. Technological Forecasting and Social Change 81, 272-286. [CrossRef]

200. Yanqing Jiang. 2014. Spatial Distribution of Foreign Direct Investment and Productivity Growth in Less Developed Regions of China. American Journal of Industrial and Business Management 04, 644-656. [CrossRef]

201. Ann E. Harrison, Justin Yifu Lin, Lixin Colin Xu. 2014. Explaining Africa’s (Dis)advantage. World Development . [CrossRef]

202. Iulia Siedschlag, Ville Kaitila, John McQuinn, Xiaoheng Zhang. 2014. International Investment and Firm Performance: Empirical Evidence from Small Open Economies. Jabrbücher für Nationalökonomie und Statistik 234:6. . [CrossRef]

203. Dolores Añón Higón, Miguel Manjón-AntolínInternational R\&D Spillovers, TFP and Institutional Distance 267-280. [CrossRef]

204. Meng Song, Nigel Driffield, Jun DuInward Investment, Technology Transfer and Innovation: Direct Evidence from China 151-173. [CrossRef] 
205. Sourafel Girma, Yundan Gong, Holger Görg, Sandra LancherosDrivers of Technology Upgrading: Do Foreign Acquisitions Matter to Chinese Firms? 251-266. [CrossRef]

206. Bruno Cirillo, Giovanni ValentiniInternational Open Innovation: Taking Stock and Moving Forward 19-46. [CrossRef]

207. Daniel Lederman, Julián Messina, Samuel Pienknagura, Jamele RigoliniForeign Direct Investment, Multinational Corporations, and Innovation 121-140. [CrossRef]

208. \#\#, Sung Jin Kang. 2013. The Effect of the FDI on Technological Progress: The Case of Indonesia Listed Manufacturing Companies. KUKJE KYUNGJE YONGU 19, 113-143. [CrossRef]

209. Shu-Chin Lin, Dong-Hyeon Kim, Yi-Chen Wu. 2013. FOREIGN DIRECT INVESTMENT AND INCOME INEQUALITY: HUMAN CAPITAL MATTERS. Journal of Regional Science 53:10.1111/jors.2013.53.issue-5, 874-896. [CrossRef]

210. Fernando Muñoz-Bullón, Maria J. Sánchez-Bueno. 2013. Multinational enterprises and domestic wages: The contingent effect of skill composition. International Business Review 22, 918-931. [CrossRef]

211. Lili Chen. 2013. Technology Spillover and Market Competition of Foreign Firms in China. China Economic Policy Review 02, 1350009. [CrossRef]

212. Lv MinTechnological spillovers of foreign-invested enterprises and technological progress of domestic enterprises: A panel study of Chinese manufacturing Industry 67-70. [CrossRef]

213. Ravi Batra, Hamid Beladi. 2013. Foreign Capital and Urban Congestion in Emerging Markets. Review of Development Economics 17:10.1111/rode.2013.17.issue-4, 676-684. [CrossRef]

214. Haiyang Li, Yan Anthea Zhang, Marjorie Lyles. 2013. Knowledge Spillovers, Search, and Creation in China's Emerging Market.\#\#\#\#\#\#\#\#\#\#\#\#\#\#\#. Management and Organization Review 9, 395-412. [CrossRef]

215. Dany Bahar, Ricardo Hausmann, Cesar A. Hidalgo. 2013. Neighbors and the evolution of the comparative advantage of nations: Evidence of international knowledge diffusion?. Journal of International Economics . [CrossRef]

216. Chunlai Chen, Yu Sheng, Christopher Findlay. 2013. Export Spillovers of FDI on China's Domestic Firms. Review of International Economics 21:10.1111/roie.2013.21.issue-5, 841-856. [CrossRef]

217. Stephen Roper, Priit Vahter, James H. Love. 2013. Externalities of openness in innovation. Research Policy 42, 1544-1554. [CrossRef]

218. Qichun He, Meng Sun, Heng-Fu Zou. 2013. FINANCIAL DEREGULATION, ABSORPTIVE CAPABILITY, TECHNOLOGY DIFFUSION AND GROWTH: EVIDENCE FROM CHINESE PANEL DATA. Journal of Applied Economics 16, 275-302. [CrossRef]

219. Masami Ishida, Tomohiro Machikita, Yasushi Ueki. 2013. How export and import platforms drive industry upgrading: five facts about emerging multinationals from southeast Asia. Asian Journal of Technology Innovation 21, 4-24. [CrossRef]

220. Yuriy Gorodnichenko, Monika Schnitzer. 2013. FINANCIAL CONSTRAINTS AND INNOVATION: WHY POOR COUNTRIES DON'T CATCH UP. Journal of the European Economic Association 11:10.1111/jeea.2013.11.issue-5, 1115-1152. [CrossRef]

221. Chiara F. Del Bo. 2013. FDI spillovers at different levels of industrial and spatial aggregation: Evidence from the electricity sector. Energy Policy 61, 1490-1502. [CrossRef]

222. María C. Latorre. 2013. On the Differential Behaviour of National and Multinational Firms: A Within- and Across-sectors Approach. The World Economy 36, 1294-1317. [CrossRef]

223. Olivier N. Godart, Holger Görg. 2013. Suppliers of multinationals and the forced linkage effect: Evidence from firm level data. Journal of Economic Behavior \& Organization 94, 393-404. [CrossRef] 
224. Huey-Ling Shiau, Chen-Jui Huang, Fong-Chyi Chen. 2013. International Involvement, Target Market Selection, and Consolidated Performance: A Firm-Level Analysis of Taiwan's FDI in China. Emerging Markets Finance and Trade 49, 184-196. [CrossRef]

225. Akinori Tomohara, Kazuhiko Yokota. 2013. Who Gains from Foreign Direct Investment-Induced Technology Spillovers? Horizontal and Vertical Linkages. Australian Economic Review 46:10.1111/ aere.v46.3, 312-324. [CrossRef]

226. Fredrik Sjöholm, Nannan Lundin. 2013. Foreign Firms and Indigenous Technology Development in the People's Republic of China. Asian Development Review 30, 49-75. [CrossRef]

227. Xia Gao, Wei Zhang. 2013. Foreign investment, innovation capacity and environmental efficiency in China. Mathematical and Computer Modelling 58, 1040-1046. [CrossRef]

228. Daniel Lederman, Taye Mengistae, Lixin Colin Xu. 2013. Microeconomic consequences and macroeconomic causes of foreign direct investment in southern African economies. Applied Economics 45, 3637-3649. [CrossRef]

229. E. Han Kim, Yao Lu. 2013. Corporate governance reforms around the world and cross-border acquisitions. Journal of Corporate Finance 22, 236-253. [CrossRef]

230. Zhenzhen Xie, Jiatao Li. 2013. Internationalization and Indigenous Technological Efforts of Emerging Economy Firms: The Effect of Multiple Knowledge Sources. Journal of International Management 19, 247-259. [CrossRef]

231. Yongbok Jeon, Byung Il Park, Pervez N. Ghauri. 2013. Foreign direct investment spillover effects in China: Are they different across industries with different technological levels?. China Economic Review 26, 105-117. [CrossRef]

232. Alex Eapen. 2013. FDI spillover effects in incomplete datasets. Journal of International Business Studies 44:7, 719-744. [CrossRef]

233. Lamia Ben Hamida. 2013. Are there regional spillovers from FDI in the Swiss manufacturing industry?. International Business Review 22, 754-769. [CrossRef]

234. Jože P. Damijan, Matija Rojec, Boris Majcen, Mark Knell. 2013. Impact of firm heterogeneity on direct and spillover effects of FDI: Micro-evidence from ten transition countries. Journal of Comparative Economics 41, 895-922. [CrossRef]

235. Fariha Kamal. 2013. DOES FIRM OWNERSHIP AFFECT SPILLOVER OPPORTUNITIES? EVIDENCE FROM CHINESE MANUFACTURING. Journal of Regional Science n/a-n/a. [CrossRef]

236. Quyen T.K. Nguyen. 2013. Can British multinational enterprises finance economic development in South East Asia?. Multinational Business Review 21, 122-147. [CrossRef]

237. Thomas Gall, Marc Schiffbauer, Julia Kubny. 2013. DYNAMIC EFFECTS OF FOREIGN DIRECT INVESTMENT WHEN CREDIT MARKETS ARE IMPERFECT. Macroeconomic Dynamics 1-35. [CrossRef]

238. Azmat Gani, Almukhtar Saif Al-Abri. 2013. Indicators of business environment, institutional quality and foreign direct investment in Gulf Cooperation Council (GCC) countries. International Review of Applied Economics 27, 515-530. [CrossRef]

239. Hou Yuan-yuan, Liu Yun, Qi Yan-ruMulti-period lagged effect of multinational corporations' technology spillover 1829-1834. [CrossRef]

240. Joseph P.H. Fan, Stuart L. Gillan, Xin Yu. 2013. Innovation or imitation?. Journal of Multinational Financial Management 23, 208-234. [CrossRef]

241. Hong Zhuang. 2013. THE EFFECT OF FDI ON LOCAL EDUCATION EXPENDITURES: EVIDENCE FROM THE UNITED STATES. Bulletin of Economic Research 65:10.1111/ boer.2013.65.issue-3, 203-224. [CrossRef] 
242. Joseph P.H. Fan, Stuart L. Gillan, Xin Yu. 2013. Property rights, R\&D spillovers, and corporate accounting transparency in China. Emerging Markets Review 15, 34-56. [CrossRef]

243. Diadié Diaw, Albert Lessoua. 2013. Natural Resources Exports, Diversification and Economic Growth of CEMAC Countries: On the Impact of Trade with China. African Development Review 25:10.1111/ afdr.v25.2, 189-202. [CrossRef]

244.\#\#\#, Joo-Yong Chon. 2013. A Multisectoral Analysis on the Productivity Effect of Foreign Direct Investment Inflows: On the Perspective of Intersectoral Technology Spillovers and Absorption Capacity. Productivity Review 27, 31-61. [CrossRef]

245. Dahai Fu, Yanrui Wu. 2013. Foreign Entry and Profitability of Domestic Firms: Evidence from China *. Asian Economic Papers 12, 34-60. [CrossRef]

246. Yasuo Sanjo. 2013. Country size and tax policy for international joint ventures in an integrated market. International Review of Economics \& Finance 27, 37-53. [CrossRef]

247. Kevin Lehnert, Mamoun Benmamoun, Hongxin Zhao. 2013. FDI Inflow and Human Development: Analysis of FDI's Impact on Host Countries' Social Welfare and Infrastructure. Thunderbird International Business Review 55:10.1002/tie.v55.3, 285-298. [CrossRef]

248. Jennifer P. Poole. 2013. Knowledge Transfers from Multinational to Domestic Firms: Evidence from Worker Mobility. Review of Economics and Statistics 95, 393-406. [CrossRef]

249. Jonathan Munemo. 2013. Examining Imports of Capital Goods From China as a Channel for Technology Transfer and Growth in Sub-Saharan Africa. Journal of African Business 14, 106-116. [CrossRef]

250. Mohammad Sharif Karimi, Law Siong Hook, Lee Chin, Zulkornain Yusop. 2013. Effect of Human Capital on Foreign Direct Investment Inflows. Journal of Economic Research (JER) 18, 79-101. [CrossRef]

251. Juan Carluccio, Thibault Fally. 2013. Foreign entry and spillovers with technological incompatibilities in the supply chain. Journal of International Economics 90, 123-135. [CrossRef]

252. Ivan A. Duran, Michael Ryan. 2013. Spillover Effects from Inward FDI on the Exporting Decisions of Chilean Manufacturing Plants. Journal of Industry, Competition and Trade . [CrossRef]

253. Massimo G. Colombo, Annalisa Croce, Samuele Murtinu. 2013. Ownership structure, horizontal agency costs and the performance of high-tech entrepreneurial firms. Small Business Economics . [CrossRef]

254. Mohsen Bahmani-Oskooee, Shady Kholdy, Ahmad Sohrabian. 2013. Do MNCs spur financial markets in corrupt host countries?. Journal of Economics and Finance 37, 308-317. [CrossRef]

255. Tieli Li, Miao Fu, Xiaolan Fu. 2013. Regional technology development path in an open developing economy: evidence from China. Applied Economics 45, 1405-1418. [CrossRef]

256. Nigel Driffield, Chris Jones. 2013. Impact of FDI, ODA and Migrant Remittances on Economic Growth in Developing Countries: A Systems Approach. The European Journal of Development Research 25:2, 173-196. [CrossRef]

257. Halis M. Yildiz. 2013. Foreign direct investment and customs union: Incentives for multilateral tariff cooperation over free trade. The Journal of International Trade \& Economic Development 22, 298-316. [CrossRef]

258. A. Yasemin Yalta. 2013. Revisiting the FDI-led growth Hypothesis: The case of China. Economic Modelling 31, 335-343. [CrossRef]

259. Chiara F. Del Bo. 2013. Productivity in electricity generation: The role of firm ownership and regional institutional quality. International Review of Applied Economics 27, 237-264. [CrossRef] 
260. Zhe Qu, Can Huang, Mingqian Zhang, Yanyun Zhao. 2013. R\&D offshoring, technology learning and R\&D efforts of host country firms in emerging economies. Research Policy 42, 502-516. [CrossRef]

261. Serguey Braguinsky, Sergey Mityakov. 2013. Foreign corporations and the culture of transparency: Evidence from Russian administrative data. Journal of Financial Economics . [CrossRef]

262. Vrinda Kadiyali, Renáta Kosová. 2013. Inter-industry employment spillovers from tourism inflows. Regional Science and Urban Economics 43, 272-281. [CrossRef]

263. Ergun Dogan, Koi Nyen Wong, Michael M. C. Yap. 2013. Turnover, ownership and productivity in Malaysian manufacturing. Journal of the Asia Pacific Economy 18, 26-50. [CrossRef]

264. Anagaw Derseh Mebratie, Arjun S. Bedi. 2013. Foreign direct investment, black economic empowerment and labour productivity in South Africa. The Journal of International Trade \& Economic Development 22, 103-128. [CrossRef]

265. Yanling Wang. 2013. Exposure to FDI and new plant survival: evidence in Canada. Canadian Journal of Economics/Revue canadienne d'économique 46, 46-77. [CrossRef]

266. Anagaw Derseh Mebratie, Peter A. G. van Bergeijk. 2013. Firm heterogeneity and development: A meta-analysis of FDI productivity spillovers. The Journal of International Trade \& Economic Development 22, 53-74. [CrossRef]

267. Jacob A. Jordaan. 2013. Firm heterogeneity and technology transfers to local suppliers: Disentangling the effects of foreign ownership, technology gap and absorptive capacity. The Journal of International Trade \& Economic Development 22, 75-102. [CrossRef]

268. Francisco García, Byungchae Jin, Robert Salomon. 2013. Does inward foreign direct investment improve the innovative performance of local firms?. Research Policy 42, 231-244. [CrossRef]

269. Naveed Iqbal Chaudhry, Asif Mehmood, Mian Saqib Mehmood. 2013. Empirical relationship between foreign direct investment and economic growth. China Finance Review International 3, 26-41. [CrossRef]

270. Rui Albuquerque, Luis Brandao-Marques, Miguel A. Ferreira, Pedro Matos. 2013. International Corporate Governance Spillovers: Evidence from Cross-Border Mergers and Acquisitions. IMF Working Papers 13, 1. [CrossRef]

271. Tomohiro Machikita, Yasushi Ueki. 2013. Knowledge transfer channels to Vietnam for process improvement. Management Decision 51, 954-972. [CrossRef]

272.\#\#, Shuai Zhai. 2013. An Empirical Study on the Export and Import Effects of Foreign Direct Investment on the Blue Economic Zone of the Shandong Peninsula in China. Journal of Distribution Science 11, 15-23. [CrossRef]

273. Deborah L. Swenson. 2013. Trade Environment Changes and the Expansion of Private Chinese Exports. Asian Economic Papers 12, 108-134. [CrossRef]

274. L. Alfaro, M.S. JohnsonForeign Direct Investment and Growth 299-309. [CrossRef]

275. C. Newman, J. Rand, F. Tarp. 2013. Industry Switching in Developing Countries. The World Bank Economic Review 27, 357-388. [CrossRef]

276. B.S. JavorcikInternational Technology Transfer and Foreign Direct Investment 311-319. [CrossRef]

277. Suyanto, Ruhul Salim. 2013. Foreign direct investment spillovers and technical efficiency in the Indonesian pharmaceutical sector: firm level evidence. Applied Economics 45, 383-395. [CrossRef]

278. S. Kalemli-Ozcan, C. Villegas-SanchezRole of Multinational Corporations in Financial Globalization 321-331. [CrossRef] 
279. Abdelhakim Hammoudi, Wadii Hatit, Lamia Rouached. 2013. Foreign Direct Investment and Training in the Host Country: The Tariff-Jumping Argument Revisited. The International Trade Journal 27, 36-62. [CrossRef]

280. Khaled Elmawazini, Gamal Atallah, Sonny Nwankwo, Yazid Dissou. 2013. US Foreign Affiliates, Technology Diffusion and Host Country Human Development: Human Development Index versus Human Capital. Industry \& Innovation 20, 69-91. [CrossRef]

281. E. Hajrizi, M. Hasani. 2013. Kosovo Investment Climate and Foreign Investors' Perception. IFAC Proceedings Volumes 46:8, 219-224. [CrossRef]

282. Micheline Goedhuys, Reinhilde Veugelers. 2012. Innovation strategies, process and product innovations and growth: Firm-level evidence from Brazil. Structural Change and Economic Dynamics 23, 516-529. [CrossRef]

283. María C. Latorre. 2012. Industry restructuring in transition after the arrival of multinationals: a general equilibrium analysis with firm-type costs differences. Post-Communist Economies 24, 441-463. [CrossRef]

284. Jong-Wha Lee, Kwanho Shin. 2012. Welfare implications of international financial integration. Japan and the World Economy 24, 235-245. [CrossRef]

285. Na Dai, Hoje Jo, Sul Kassicieh. 2012. Cross-border venture capital investments in Asia: Selection and exit performance. Journal of Business Venturing 27, 666-684. [CrossRef]

286. Klara Sabirianova Peter, Jan Svejnar, Katherine Terrell. 2012. Foreign Investment, Corporate Ownership, and Development: Are Firms in Emerging Markets Catching Up to the World Standard?. Review of Economics and Statistics 94, 981-999. [CrossRef]

287. Jung Won Sonn, Dongheon Lee. 2012. Revisiting the branch plant syndrome: Review of literature on foreign direct investment and regional development in Western advanced economies. International Journal of Urban Sciences 16, 243-259. [CrossRef]

288. Maria Cipollina, Giorgia Giovannetti, Filomena Pietrovito, Alberto F. Pozzolo. 2012. FDI and Growth: What Cross-country Industry Data Say. The World Economy 35:10.1111/twec.2012.35.issue-11, 1599-1629. [CrossRef]

289. Judy Hsu, Ya-Ping Chuang. 2012. International technology spillovers and innovation: Evidence from Taiwanese high-tech firms. The Journal of International Trade \& Economic Development 1-15. [CrossRef]

290. Sajid Anwar, Sizhong Sun. 2012. FDI and market entry/exit: Evidence from China. Journal of Asian Economics 23, 487-498. [CrossRef]

291. Suyanto, Harry Bloch, Ruhul A. Salim. 2012. Foreign Direct Investment Spillovers and Productivity Growth in Indonesian Garment and Electronics Manufacturing. Journal of Development Studies 48, 1397-1411. [CrossRef]

292. Tajul Ariffin Masron, Abdul Hadi Zulkafli, Haslindar Ibrahim. 2012. Spillover Effects of FDI within Manufacturing Sector in Malaysia. Procedia - Social and Bebavioral Sciences 58, 1204-1211. [CrossRef]

293. Alessandra Perri, Ulf Andersson, Phillip C. Nell, Grazia D. Santangelo. 2012. Balancing the tradeoff between learning prospects and spillover risks: MNC subsidiaries' vertical linkage patterns in developed countries. Journal of World Business . [CrossRef]

294. Tomas Havranek, Zuzana Irsova. 2012. Survey Article: Publication Bias in the Literature on Foreign Direct Investment Spillovers. Journal of Development Studies 48, 1375-1396. [CrossRef]

295. Sui Yining, Huang Yaning, Sun Chenhui, Zhang DixinCompetitive Mechanism of FDI and Timelag of Spillovers 71-74. [CrossRef]

296. DILUPA NAKANDALA, TIM TURPIN, TERRENCE SLOAN. 2012. THE DYNAMICS OF TECHNOLOGY MANAGEMENT PRACTICES IN LOCAL FIRMS IN FOREIGN 
PARTNERSHIPS IN THE CONTEXT OF A LESS DEVELOPED ECONOMY. International Journal of Innovation and Technology Management 09, 1250039. [CrossRef]

297. Erik van der Marel. 2012. Trade in Services and TFP: The Role of Regulation. The World Economy no-no. [CrossRef]

298. Shireen AlAzzawi. 2012. Innovation, productivity and foreign direct investment-induced R\&D spillovers. The Journal of International Trade \& Economic Development 21, 615-653. [CrossRef]

299. Evangelia Desli, Pavlos Gkasis, Persefoni Tsaliki. 2012. An alternative approach to the monitoring of technological diffusion via foreign direct investment: evidence from the Greek manufacturing sector. International Review of Applied Economics 26, 687-707. [CrossRef]

300. Dao Thi Hong Nguyen, Sizhong Sun. 2012. FDI and Domestic Firms' Export Behaviour: Evidence from Vietnam*. Economic Papers: A journal of applied economics and policy 31:10.1111/ ecpa.2012.31.issue-3, 380-390. [CrossRef]

301. Horst Raff, Michael Ryan, Frank Stähler. 2012. Firm Productivity and the Foreign-Market Entry Decision. Journal of Economics \& Management Strategy 21:10.1111/jems.2012.21.issue-3, 849-871. [CrossRef]

302. Deborah L. Swenson, Huiya Chen. 2012. Multinational Exposure and the Quality of New Chinese Exports. Oxford Bulletin of Economics and Statistics no-no. [CrossRef]

303. Xun-yi Liu, Bo YuFDI spillover effects on China's economic development 936-943. [CrossRef]

304. Chun-yan Li, Xiao-hui HuThe recognition and application of FDI motivation 1084-1088. [CrossRef]

305. MEHMET HUSEYIN BILGIN, CHI KEUNG MARCO LAU, ENDER DEMIR. 2012. TECHNOLOGY TRANSFER, FINANCE CHANNELS, AND SME PERFORMANCE: NEW EVIDENCE FROM DEVELOPING COUNTRIES. The Singapore Economic Review 57, 1250020. [CrossRef]

306. Roberto Martin N Galang. 2012. Government efficiency and international technology adoption: The spread of electronic ticketing among airlines. Journal of International Business Studies 43:7, 631-654. [CrossRef]

307. Ayse Kaya, James T. Walker. 2012. The legitimacy of foreign investors. Multinational Business Review 20, 266-295. [CrossRef]

308. Laura Alfaro, Maggie Xiaoyang Chen. 2012. Surviving the Global Financial Crisis: Foreign Ownership and Establishment Performance. American Economic Journal: Economic Policy 4:3, 30-55. [Abstract] [View PDF article] [PDF with links]

309. Wu QingyanAn empirical analysis of the impact of FDI on China's pharmaceutical intra- industry trade 804-808. [CrossRef]

310. Annalisa Croce, José Martí, Samuele Murtinu. 2012. The impact of venture capital on the productivity growth of European entrepreneurial firms: 'Screening' or 'value added' effect?. Journal of Business Venturing . [CrossRef]

311. Khaled Elmawazini, Sonny Nwankwo. 2012. Foreign direct investment: Technology gap effects on international business capabilities of sub-Saharan Africa. Thunderbird International Business Review 54, 457-467. [CrossRef]

312. Xiaolan Fu. 2012. Foreign Direct Investment and Managerial Knowledge Spillovers through the Diffusion of Management Practices. Journal of Management Studies 49:10.1111/joms.2012.49.issue-5, 970-999. [CrossRef]

313. Kunal Dasgupta. 2012. Learning and knowledge diffusion in a global economy. Journal of International Economics 87, 323-336. [CrossRef]

314. Danny T. Wang, Flora F. Gu, David K. Tse, Chi Kin (Bennett) Yim. 2012. When does FDI matter? The roles of local institutions and ethnic origins of FDI. International Business Review . [CrossRef] 
315. J. Rosell-Martinez, P. Sanchez-Sellero. 2012. Foreign direct investment and technical progress in Spanish manufacturing. Applied Economics 44, 2473-2489. [CrossRef]

316. Charles. K. D. Adjasi, Joshua Abor, Kofi A. Osei, Ernestine E. Nyavor-Foli. 2012. FDI and economic activity in Africa: The role of local financial markets. Thunderbird International Business Review 54, 429-439. [CrossRef]

317. Petr Pavlínek. 2012. The Internationalization of Corporate R\&D and the Automotive Industry R\&D of East-Central Europe. Economic Geography 88:10.1111/ecge.2012.88.issue-3, 279-310. [CrossRef]

318. Ellis Luther Osabutey, Yaw A. Debrah. 2012. Foreign direct investment and technology transfer policies in Africa: A review of the Ghanaian experience. Thunderbird International Business Review 54, 441-456. [CrossRef]

319. Luosha Du, Ann Harrison, Gary H. Jefferson. 2012. Testing for horizontal and vertical foreign investment spillovers in China, 1998-2007. Journal of Asian Economics 23, 234-243. [CrossRef]

320. Keith Pilbeam, Neringa Oboleviciute. 2012. Does Foreign Direct Investment Crowd In or Crowd Out Domestic Investment? Evidence from the European Union. The Journal of Economic Asymmetries 9 , 89-104. [CrossRef]

321. Banri Ito, Naomitsu Yashiro, Zhaoyuan Xu, XiaoHong Chen, Ryuhei Wakasugi. 2012. How do Chinese industries benefit from FDI spillovers?. China Economic Review 23, 342-356. [CrossRef]

322. Deniz Erdem. 2012. Foreign direct investments, energy efficiency, and innovation dynamics. Mineral Economics 24, 119-133. [CrossRef]

323. Victor Zitian Chen, Jing Li, Daniel M. Shapiro. 2012. International reverse spillover effects on parent firms: Evidences from emerging-market MNEs in developed markets. European Management Journal 30, 204-218. [CrossRef]

324. Jingtao Yi, Chengqi Wang, Mario Kafouros. 2012. The effects of innovative capabilities on exporting: Do institutional forces matter?. International Business Review . [CrossRef]

325. Xin Wang. 2012. Foreign direct investment and innovation in China's e-commerce sector. Journal of Asian Economics 23, 288-301. [CrossRef]

326. Yanling Wang. 2012. Openness and Productivity: The Role of Imports, FDI and International Telecommunications. Latin American Journal of Economics 49:10.7764/LAJE.49.1, 125-145. [CrossRef]

327. Dierk Herzer. 2012. How Does Foreign Direct Investment Really Affect Developing Countries' Growth?. Review of International Economics 20:10.1111/roie.2012.20.issue-2, 396-414. [CrossRef]

328. Matilde Bombardini, Christopher J. Kurz, Peter M. Morrow. 2012. Ricardian trade and the impact of domestic competition on export performance. Canadian Journal of Economics/Revue canadienne d'économique 45:10.1111/caje.2012.45.issue-2, 585-612. [CrossRef]

329. Nadia Doytch, Merih Uctum. 2012. Sectoral Growth Effects of Cross-Border Mergers and Acquisitions. Eastern Economic Journal 38:3, 319-330. [CrossRef]

330. Luca Grilli, Samuele Murtinu. 2012. Do public subsidies affect the performance of new technologybased firms? The importance of evaluation schemes and agency goals. Prometheus 1-15. [CrossRef]

331. Balázs Szent-Iványi, Gábor Vigvári. 2012. Spillovers from foreign direct investment in Central and Eastern Europe. Society and Economy 34, 51-72. [CrossRef]

332. Anusha Chari, Wenjie Chen, Kathryn M E Dominguez. 2012. Foreign Ownership and Firm Performance: Emerging Market Acquisitions in the United States. IMF Economic Review 60, 1-42. [CrossRef]

333. Marcela Miozzo, Mo Yamin, Pervez N. Ghauri. 2012. Strategy and structure of service multinationals and their impact on linkages with local firms. The Service Industries Journal 1-21. [CrossRef] 
334. Ali Al-Sadig. 2012. The effects of foreign direct investment on private domestic investment: evidence from developing countries. Empirical Economics . [CrossRef]

335. Oluwatosin Adeniyi, Olusegun Omisakin, Festus O. Egwaikhide, Abimbola Oyinlola. 2012. Foreign Direct Investment, Economic Growth and Financial Sector Development in Small Open Developing Economies. Economic Analysis and Policy 42, 105-127. [CrossRef]

336. Pao-Li Chang, Chia-Hui Lu. 2012. Risk and the technology content of FDI: A dynamic model. Journal of International Economics 86, 306-317. [CrossRef]

337. Koichiro Kimura. 2012. Does Foreign Direct Investment Affect the Growth of Local Firms? The Case of China's Electrical and Electronics Industry. China \& World Economy 20:10.1111/ cwe.2012.20.issue-2, 98-120. [CrossRef]

338. Antonello Zanfei. 2012. Effects, Not Externalities. The European Journal of Development Research 24:1, 8-14. [CrossRef]

339. Rajneesh Narula, Nigel Driffield. 2012. Does FDI Cause Development? The Ambiguity of the Evidence and Why it Matters. The European Journal of Development Research 24:1, 1-7. [CrossRef]

340. Yonghong Tu, Xiao Tan. 2012. Technology spillovers of FDI in ASEAN sourcing from local and abroad. China Finance Review International 2, 78-94. [CrossRef]

341. Abdul Adamu, Barnabas Embugus BardeForeign Direct Investment and the Performance of Manufacturing Firms in Nigeria 171-183. [CrossRef]

342. Dong-Hyeon Kim, Shu-Chin Lin, Yu-Bo Suen. 2012. Dynamic Effects of Financial Openness on Economic Growth and Macroeconomic Uncertainty. Emerging Markets Finance and Trade 48, 25-54. [CrossRef]

343. Dolores Añón Higón, Miguel Manjón Antolín. 2012. Multinationality, foreignness and institutional distance in the relation between R\&D and productivity. Research Policy . [CrossRef]

344. Siwage Dharma Negara, Latif Adam. 2012. Foreign Direct Investment and Firms' Productivity Level Lesson Learned from Indonesia. ASEAN ECONOMIC BULLETIN 29, 116. [CrossRef]

345. Yih-Luan Chyi, Yee-Man Lai, Wen-Hsien Liu. 2012. Knowledge spillovers and firm performance in the high-technology industrial cluster. Research Policy . [CrossRef]

346. Khaled Elmawazini. 2012. Foreign affiliates, export success of local firms and host country innovation capability. The Journal of High Technology Management Research 23, 103-111. [CrossRef]

347. Tomohiro Machikita, Yasushi Ueki. 2012. Impacts of incoming knowledge on product innovation: technology transfer in auto-related industries in developing economies. Asian Journal of Technology Innovation 20, 9-27. [CrossRef]

348. Akinori TomoharaInward FDI and the Size of the Market: Hosting MNCs or Promoting Domestic Companies? 157-171. [CrossRef]

349. Bin Guo, Xiaoling Chen. 2011. How does FDI influence industry-level knowledge production efficiency in China?. Asian Journal of Technology Innovation 19, 263-277. [CrossRef]

350. Eunsuk Hong, Laixiang Sun. 2011. Foreign Direct Investment and Total Factor Productivity in China: A Spatial Dynamic Panel Analysis*. Oxford Bulletin of Economics and Statistics 73:10.1111/ obes.2011.73.issue-6, 771-791. [CrossRef]

351. Reinhilde Veugelers. 2011. Assessing the potential for knowledge-based development in the transition countries of Central and Eastern Europe, the Caucasus and Central Asia. Society and Economy 33, 475-504. [CrossRef]

352. Xiaolan Fu. 2011. Processing Trade, FDI and the Exports of Indigenous Firms: Firm-Level Evidence from Technology-Intensive Industries in China. Oxford Bulletin of Economics and Statistics 73:10.1111/ obes.2011.73.issue-6, 792-817. [CrossRef] 
353. Hailin Liao, Xiaohui Liu, Chengang Wang. 2011. Knowledge spillovers, absorptive capacity and total factor productivity in China's manufacturing firms. International Review of Applied Economics 1-15. [CrossRef]

354. Bahar Bayraktar Saglam, Selin Sayek. 2011. MNEs and wages: The role of productivity spillovers and imperfect labor markets. Economic Modelling 28, 2736-2742. [CrossRef]

355. Xiaolan Fu, Jing Zhang. 2011. Technology transfer, indigenous innovation and leapfrogging in green technology: the solar-PV industry in China and India. Journal of Chinese Economic and Business Studies 9, 329-347. [CrossRef]

356. Leopoldo Laborda Castillo, Daniel Sotelsek Salem, Jose Luis Guasch. 2011. Innovative and Absorptive Capacity of International Knowledge: An Empirical Analysis of Productivity Sources in Latin American Countries. Latin American Business Review 12, 309-335. [CrossRef]

357. Lingyun Huang, Xiaming Liu, Lei Xu. 2011. Regional Innovation and Spillover Effects of Foreign Direct Investment in China: A Threshold Approach. Regional Studies 1-14. [CrossRef]

358. Majella Giblin, Paul Ryan. 2011. Tight Clusters or Loose Networks? The Critical Role of Inward Foreign Direct Investment in Cluster Creation. Regional Studies 1-14. [CrossRef]

359. Chun-Hung Lin, Chia-Ming Lee, Chih-Hai Yang. 2011. Does foreign direct investment really enhance China's regional productivity?. The Journal of International Trade \& Economic Development 1-28. [CrossRef]

360. Beata S. Javorcik, Mariana Spatareanu. 2011. Does it matter where you come from? Vertical spillovers from foreign direct investment and the origin of investors. Journal of Development Economics 96, 126-138. [CrossRef]

361. Andreas Waldkirch. 2011. Comparative advantage FDI? A host country perspective. Review of World Economics 147, 485-505. [CrossRef]

362. JACOB A. JORDAAN. 2011. Local Sourcing and Technology Spillovers to Mexican Suppliers: How Important are FDI and Supplier Characteristics?. Growth and Change 42:10.1111/ grow.2011.42.issue-3, 287-319. [CrossRef]

363. Sanja Samirana Pattnayak, Shandre M. Thangavelu. 2011. Linkages and technology spillovers in the presence of foreign firms. Journal of Economic Studies 38, 275-286. [CrossRef]

364. Ya-Chin Wang, Leonard F.S. Wang. 2011. Entry Mode, Technology Spillover and Host Country Welfare. Asia-Pacific Journal of Accounting \& Economics 18, 125-143. [CrossRef]

365. Galina Hale, Cheryl Long. 2011. Did Foreign Direct Investment Put an Upward Pressure on Wages in China?. IMF Economic Review 59, 404-430. [CrossRef]

366. Zejun HeTechnology Spillover of FDI and Industrial Characteristics - The Empirical Evidence of China's High-Tech Industries 1-4. [CrossRef]

367. Jacob A. Jordaan. 2011. Cross-sectional estimation of FDI spillovers when FDI is endogenous: OLS and IV estimates for Mexican manufacturing industries. Applied Economics 43, 2451-2463. [CrossRef]

368. Donghui Li, Quang N. Nguyen, Peter K. Pham, Steven X. Wei. 2011. Large Foreign Ownership and Firm-Level Stock Return Volatility in Emerging Markets. Journal of Financial and Quantitative Analysis 46, 1127-1155. [CrossRef]

369. Yasuyuki Todo, Weiying Zhang, Lei-An Zhou. 2011. Intra-industry Knowledge Spillovers from Foreign Direct Investment in Research and Development: Evidence from China's "Silicon Valley". Review of Development Economics 15:10.1111/rode.2011.15.issue-3, 569-585. [CrossRef]

370. Lamia Ben Hamida. 2011. FDI and spillovers in the Swiss services/construction industry. Critical perspectives on international business 7, 224-249. [CrossRef]

371. Wang ZhaoyangAnalysis of actual value of foreign investment and Wuhan Regional Technical Innovation Ability 293-296. [CrossRef] 
372. Xiaolan Fu, Yundan Gong. 2011. Indigenous and Foreign Innovation Efforts and Drivers of Technological Upgrading: Evidence from China. World Development 39, 1213-1225. [CrossRef]

373. Xiaolan Fu, Carlo Pietrobelli, Luc Soete. 2011. The Role of Foreign Technology and Indigenous Innovation in the Emerging Economies: Technological Change and Catching-up. World Development 39, 1204-1212. [CrossRef]

374. Nadine McCloud, Subal C. Kumbhakar. 2011. Institutions, foreign direct investment and growth: a hierarchical Bayesian approach. Journal of the Royal Statistical Society: Series A (Statistics in Society) no-no. [CrossRef]

375. Abdul Baseer QaziAscertaining knowledge flows through labor mobility in the ICT sector of Pakistan 1-7. [CrossRef]

376. Fabian Barthel, Matthias Busse, Robert Osei. 2011. The Characteristics and Determinants of FDI in Ghana. The European Journal of Development Research 23:3, 389-408. [CrossRef]

377. Wen-Chung Hsu, Xingbo Gao, Jianhua Zhang, Hsin Mei Lin. 2011. The effects of outward FDI on home-country productivity. Journal of Chinese Economic and Foreign Trade Studies 4, 99-116. [CrossRef]

378. Sofiane Ghali, Sami Rezgui. 2011. FDI Contribution to Technical Efficiency in the Tunisian Manufacturing Sector: Evidence from Micro-panel Data. International Economic Journal 25, 319-339. [CrossRef]

379. Xinpeng Xu, Yu Sheng. 2011. Productivity Spillovers from Foreign Direct Investment: Firm-Level Evidence from China. World Development . [CrossRef]

380. Meghana Ayyagari, Asli Demirgüç-Kunt, Vojislav Maksimovic. 2011. Firm Innovation in Emerging Markets: The Role of Finance, Governance, and Competition. Journal of Financial and Quantitative Analysis 1-70. [CrossRef]

381. Chengqi Wang, Ziliang Deng, Mario I. Kafouros, Yan Chen. 2011. Reconceptualizing the spillover effects of foreign direct investment: A process-dependent approach. International Business Review . [CrossRef]

382. Aljaž Kunčič, Marjan Svetličič. 2011. Who's Who in Foreign Direct Investment Promotion. Eastern European Economics 49, 66-88. [CrossRef]

383. Renshu Jin, Rendong HanThe comparative study of the effects of FDI from US and Japan on China: Empirical study based on distributed lag model 1-6. [CrossRef]

384. Jan Hanousek, Evžen Kočenda, Mathilde Maurel. 2011. Direct and indirect effects of FDI in emerging European markets: A survey and meta-analysis. Economic Systems . [CrossRef]

385. Vassilis Monastiriotis, Rodrigo Alegria. 2011. Origin of FDI and Intra-Industry Domestic Spillovers: The Case of Greek and European FDI in Bulgaria. Review of Development Economics 15:10.1111/ rode.2011.15.issue-2, 326-339. [CrossRef]

386. GALINA HALE, CHERYL LONG. 2011. ARE THERE PRODUCTIVITY SPILLOVERS FROM FOREIGN DIRECT INVESTMENT IN CHINA?. Pacific Economic Review 16:10.1111/ paer.2011.16.issue-2, 135-153. [CrossRef]

387. Hoi Quoc Le, Richard Pomfret. 2011. Technology spillovers from foreign direct investment in Vietnam: horizontal or vertical spillovers?. Journal of the Asia Pacific Economy 16, 183-201. [CrossRef]

388. Jens M. Arnold, Beata S. Javorcik, Aaditya Mattoo. 2011. Does services liberalization benefit manufacturing firms?. Journal of International Economics . [CrossRef]

389. K.-M. Nam. 2011. Learning through the international joint venture: lessons from the experience of China's automotive sector. Industrial and Corporate Change . [CrossRef]

390. Shireen AlAzzawi. 2011. Multinational Corporations and Knowledge Flows: Evidence from Patent Citations. Economic Development and Cultural Change 59, 649-680. [CrossRef] 
391. D. Anon Higon, M. Manjon Antolin, J. A. Manez. 2011. Multinationals, R\&D, and productivity: evidence for UK manufacturing firms. Industrial and Corporate Change 20, 641-659. [CrossRef]

392. Hanna Pesola. 2011. Labour Mobility and Returns to Experience in Foreign Firms*. Scandinavian Journal of Economics no-no. [CrossRef]

393. Dolores Añón Higón, Nicholas Vasilakos. 2011. Foreign Direct Investment Spillovers: Evidence from the British Retail Sector. The World Economy 34:10.1111/twec.2011.34.issue-4, 642-666. [CrossRef]

394. Nadia Doytch, Merih Uctum. 2011. Does the worldwide shift of FDI from manufacturing to services accelerate economic growth? A GMM estimation study. Journal of International Money and Finance 30, 410-427. [CrossRef]

395. Chee-Keong Choong. 2011. Does domestic financial development enhance the linkages between foreign direct investment and economic growth?. Empirical Economics . [CrossRef]

396. Sizhong Sun. 2011. Foreign Direct Investment and Technology Spillovers in China's Manufacturing Sector. Chinese Economy 44, 25-42. [CrossRef]

397. Xiaowen Tian, Vai Io Lo, Shuanglin Lin, Shunfeng Song. 2011. Cross-region FDI productivity spillovers in transition economies: evidence from China. Post-Communist Economies 23, 105-118. [CrossRef]

398. Wenjie Chen. 2011. The effect of investor origin on firm performance: Domestic and foreign direct investment in the United States\#. Journal of International Economics 83, 219-228. [CrossRef]

399. Guoqing Zhao, Zhongyuan Zhang. 2011. Does method selection matter? A new look at FDI and human capital in Chinese high-tech industries. Frontiers of Economics in China 6, 36-54. [CrossRef]

400. Fabio Montobbio, Valerio Sterzi. 2011. Inventing together: exploring the nature of international knowledge spillovers in Latin America. Journal of Evolutionary Economics 21, 53-89. [CrossRef]

401. Thierry Tressel, Thierry Verdier. 2011. Financial Globalization and the Governance of Domestic Financial Intermediaries. Journal of the European Economic Association 9:10.1111/jeea.2011.9.issue-1, 130-175. [CrossRef]

402. Christina Hallin, Christine Holmström Lind. 2011. Revisiting the external impact of MNCs: An empirical study of the mechanisms behind knowledge spillovers from MNC subsidiaries. International Business Review . [CrossRef]

403. Grazia Domenica Santangelo. 2011. The tension of information sharing: Effects on subsidiary embeddedness. International Business Review . [CrossRef]

404. Ragnhild Balsvik. 2011. Is Labor Mobility a Channel for Spillovers from Multinationals? Evidence from Norwegian Manufacturing. Review of Economics and Statistics 93, 285-297. [CrossRef]

405. José Guimón. 2011. Policies to benefit from the globalization of corporate R\&D: An exploratory study for EU countries. Technovation 31, 77-86. [CrossRef]

406. Giorgia Maffini, Socrates Mokkas. 2011. Profit Shifting and Measured Productivity of Multinational Firms*. Oxford Bulletin of Economics and Statistics 73:10.1111/obes.2010.73.issue-1, 1-20. [CrossRef]

407. Qian Gu, Jane W Lu. 2011. Effects of inward investment on outward investment: The venture capital industry worldwide 1985-2007. Journal of International Business Studies 42:2, 263-284. [CrossRef]

408. Xiaolan Fu, Christian Helmers, Jing Zhang. 2011. The two faces of foreign management capabilities: FDI and productive efficiency in the UK retail sector. International Business Review . [CrossRef]

409. Andrés Villarreal, Arthur Sakamoto. 2011. Bringing the firms into globalization research: The effects of foreign investment and exports on wages in Mexican manufacturing firms. Social Science Research . [CrossRef]

410. Krista Tuomi. 2011. The Role of the Investment Climate and Tax Incentives in the Foreign Direct Investment Decision: Evidence from South Africa. Journal of African Business 12, 133-147. [CrossRef] 
411. Wan Kunyang, Yu ShujuanUniversity \&amp; FDI knowledge spillovers and large \&amp; mediumsized industrial enterprises technology innovation \&\#8212; Knowledge production function model based on panel data 488-491. [CrossRef]

412. R. Balsvik, S. A. Haller. 2011. Foreign firms and host-country productivity: does the mode of entry matter?. Oxford Economic Papers 63, 158-186. [CrossRef]

413. Priit Vahter. 2011. Does FDI Spur Productivity, Knowledge Sourcing and Innovation by Incumbent Firms? Evidence from Manufacturing Industry in Estonia. The World Economy 34:8, 1308. [CrossRef]

414. Jan Hagemejer, Marcin Kolasa. 2011. Internationalisation and Economic Performance of Enterprises: Evidence from Polish Firm-level Data. The World Economy 34:10.1111/twec.2011.34.issue-1, 74-100. [CrossRef]

415. Haiyang Zhang, Tetsushi Sonobe. 2011. Development of Science and Technology Parks in China, 1988-2008. Economics: The Open-Access, Open-Assessment E-Journal 5, 1. [CrossRef]

416. Michael Hübler. 2011. Technology diffusion under contraction and convergence: A CGE analysis of China. Energy Economics 33, 131-142. [CrossRef]

417. Haiyang Zhang, Tetsushi Sonobe. 2011. Business Incubators in China: An Inquiry into the Variables Associated with Incubatee Success. Economics: The Open-Access, Open-Assessment E-Journal 5, 1. [CrossRef]

418. Pervez N. Ghauri, Rebecca FirthThe Impact of Foreign Direct Investment on Local Firms: Western Firms in Emerging Markets 379-405. [CrossRef]

419. Cheng-Hua Tzeng, Paul W. Beamish, Shih-Fen Chen. 2010. Institutions and entrepreneurship development: High-technology indigenous firms in China and Taiwan. Asia Pacific Journal of Management . [CrossRef]

420. Hyuk Hwang Kim, June Dong Kim. 2010. Productivity Spillover Effect of Foreign Direct Investment into Korea. Journal of East Asian Economic Integration 14:2, 21-46. [CrossRef]

421. Kazunobu Hayakawa, Tomohiro Machikita, Fukunari Kimura. 2010. GLOBALIZATION AND PRODUCTIVITY: A SURVEY OF FIRM-LEVEL ANALYSIS. Journal of Economic Surveys nono. [CrossRef]

422. Sajid Anwar, Lan Phi Nguyen. 2010. Absorptive capacity, foreign direct investment-linked spillovers and economic growth in Vietnam. Asian Business \& Management 9, 553-570. [CrossRef]

423. SUYANTO, Ruhul A. SALIM. 2010. SOURCES OF PRODUCTIVITY GAINS FROM FDI IN INDONESIA: IS IT EFFICIENCY IMPROVEMENT OR TECHNOLOGICAL PROGRESS?. The Developing Economies 48, 450-472. [CrossRef]

424. Miao Wang. 2010. Foreign direct investment and domestic investment in the host country: evidence from panel study. Applied Economics 42, 3711-3721. [CrossRef]

425. Sizhong Sun. 2010. Heterogeneity of FDI Export Spillovers and Its Policy Implications: The Experience of China. Asian Economic Journal 24, 289-303. [CrossRef]

426. Yang Li, Shin-Yi Chen. 2010. The Impact of FDI on the Productivity of Chinese Economic Regions. Asia-Pacific Journal of Accounting \& Economics 17, 299-312. [CrossRef]

427. H Saranga, R D Banker. 2010. Productivity and technical changes in the Indian pharmaceutical industry. Journal of the Operational Research Society 61:12, 1777-1788. [CrossRef]

428. Patrik Karpaty, Richard Kneller. 2010. Demonstration or congestion? Export spillovers in Sweden. Review of World Economics . [CrossRef]

429. Christer Ljungwall, Patrik Gustavsson Tingvall. 2010. Is China different? A meta-analysis of the effects of foreign direct investment on domestic firms. Journal of Chinese Economic and Business Studies 8, 353-371. [CrossRef] 
430. Renáta Kosová. 2010. Do Foreign Firms Crowd Out Domestic Firms? Evidence from the Czech Republic. Review of Economics and Statistics 92, 861-881. [CrossRef]

431. Anabel Marin, Subash Sasidharan. 2010. Heterogeneous MNC subsidiaries and technological spillovers: Explaining positive and negative effects in India. Research Policy 39, 1227-1241. [CrossRef]

432. James E. Rauch. 2010. Development through synergistic reforms. Journal of Development Economics 93, 153-161. [CrossRef]

433. He Qing-song, Wang Dong-mei, Cai LinFDI technology spillover effects under reform and openingup: Evidence from China 819-824. [CrossRef]

434. Yanling Wang. 2010. FDI and productivity growth: the role of inter-industry linkages. Canadian Journal of Economics/Revue canadienne d'économique 43, 1243-1272. [CrossRef]

435. Salvador Barrios, Holger Görg, Eric Strobl. 2010. Spillovers through backward linkages from multinationals: Measurement matters!. European Economic Review . [CrossRef]

436. Marian Leimbach, Lavinia Baumstark. 2010. The impact of capital trade and technological spillovers on climate policies. Ecological Economics 69, 2341-2355. [CrossRef]

437. Roger Smeets, Yingqi Wei. 2010. Productivity Effects of United States Multinational Enterprises: The Roles of Market Orientation and Regional Integration. Regional Studies 44, 949-963. [CrossRef]

438. Shoji Haruna, Naoto Jinji, Xingyuan Zhang. 2010. Patent citations, technology diffusion, and international trade: evidence from Asian countries. Journal of Economics and Finance 34, 365-390. [CrossRef]

439. Jacob A. Jordaan, Eduardo Rodriguez-Oreggia. 2010. Regional growth in Mexico under trade liberalisation: how important are agglomeration and FDI?. The Annals of Regional Science . [CrossRef]

440. José Brambila-Macias, Isabella Massa. 2010. The Global Financial Crisis and Sub-Saharan Africa: The Effects of Slowing Private Capital Inflows on Growth*. African Development Review 22:10.1111/ afdr.2010.22.issue-3, 366-377. [CrossRef]

441. Xuan-Vinh Vo. 2010. Net private capital flows and economic growth-the case of emerging Asian economies. Applied Economics 42, 3135-3146. [CrossRef]

442. Pedro de Faria, Wolfgang Sofka. 2010. Knowledge protection strategies of multinational firms-A cross-country comparison. Research Policy 39, 956-968. [CrossRef]

443. Jiyong Chen, Wei Liu, Yibo Zhang, Yangyi Sheng. 2010. An empirical study on FDI international knowledge spillovers and regional economic development in China. Frontiers of Economics in China 5, 489-508. [CrossRef]

444. Rajneesh Narula, John Dunning. 2010. Multinational Enterprises, Development and Globalization: Some Clarifications and a Research Agenda. Oxford Development Studies 38, 263-287. [CrossRef]

445. Yifei Sun, Debin Du. 2010. Determinants of industrial innovation in China: Evidence from its recent economic census. Technovation 30, 540-550. [CrossRef]

446. Xiaohui Liu, Jiangyong Lu, Igor Filatotchev, Trevor Buck, Mike Wright. 2010. Returnee entrepreneurs, knowledge spillovers and innovation in high-tech firms in emerging economies. Journal of International Business Studies 41:7, 1183-1197. [CrossRef]

447. Macrofinancial Linkages . [CrossRef]

448. M. Brahmbhatt, A. Hu. 2010. Ideas and Innovation in East Asia. The World Bank Research Observer 25, 177-207. [CrossRef]

449. Rossitza B. Wooster, David S. Diebel. 2010. Productivity Spillovers from Foreign Direct Investment in Developing Countries: A Meta-Regression Analysis. Review of Development Economics 14:10.1111/ rode.2010.14.issue-3, 640-655. [CrossRef] 
450. Kunyang Wan, Shujuan YuAn Empirical Study on FDI Knowledge Spillover: Spatial Econometric Models Based on Panel Data 1-5. [CrossRef]

451. Ronald U. Mendoza. 2010. Trade-induced Learning and Industrial Catch-up*. The Economic Journal 120:10.1111/ecoj.2010.120.issue-546, F313-F350. [CrossRef]

452. Xiaowen Tian. 2010. Managing FDI technology spillovers: A challenge to TNCs in emerging markets. Journal of World Business 45, 276-284. [CrossRef]

453. S. Menghinello, L. De Propris, N. Driffield. 2010. Industrial districts, inward foreign investment and regional development. Journal of Economic Geography 10, 539-558. [CrossRef]

454. Kazuyuki Motohashi, Yuan Yuan. 2010. Productivity impact of technology spillover from multinationals to local firms: Comparing China's automobile and electronics industries. Research Policy 39, 790-798. [CrossRef]

455. Wei Zhao, Ling Liu, Ting Zhao. 2010. The contribution of outward direct investment to productivity changes within China, 1991-2007. Journal of International Management 16, 121-130. [CrossRef]

456. Vinish Kathuria. 2010. Does the Technology Gap Influence Spillovers? A Post-liberalization Analysis of Indian Manufacturing Industries. Oxford Development Studies 38, 145-170. [CrossRef]

457. Andreas Waldkirch. 2010. The Effects of Foreign Direct Investment in Mexico since NAFTA. World Economy 33:10.1111/twec.2010.33.issue-5, 710-745. [CrossRef]

458. Alla Lileeva. 2010. The benefits to domestically owned plants from inward direct investment: the role of vertical linkages. Canadian Journal of Economics/Revue canadienne d'économique 43:10.1111/ caje.2010.43.issue-2, 574-603. [CrossRef]

459. Jessie Poon, Suksawat Sajarattanochote. 2010. Asian Transnational Enterprises and Technology Transfer in Thailand. European Planning Studies 18, 691-707. [CrossRef]

460. Jing Xu, Hanqin Zhang, Jiajia Wu. 2010. China's policies on foreign-invested travel agencies upon its entry to the WTO. International Journal of Contemporary Hospitality Management 22, 360-381. [CrossRef]

461. Shunsuke Managi, Samuel Mulenga Bwalya. 2010. Foreign direct investment and technology spillovers in sub-Saharan Africa. Applied Economics Letters 17, 605-608. [CrossRef]

462. Denvil Duncan, Klara Sabirianova Peter. 2010. Does labour supply respond to a flat tax?. Economics of Transition 18:10.1111/ecot.2010.18.issue-2, 365-404. [CrossRef]

463. Christian A. L. Hilber, Ioan Voicu. 2010. Agglomeration Economies and the Location of Foreign Direct Investment: Empirical Evidence from Romania. Regional Studies 44, 355-371. [CrossRef]

464. Oscar Bajo-Rubio, Carmen Díaz-Mora, Carmen Díaz-Roldán. 2010. Foreign Direct Investment and Regional Growth: An Analysis of the Spanish Case. Regional Studies 44, 373-382. [CrossRef]

465. Laura Alfaro, Areendam Chanda, Sebnem Kalemli-Ozcan, Selin Sayek. 2010. Does foreign direct investment promote growth? Exploring the role of financial markets on linkages\#. Journal of Development Economics 91, 242-256. [CrossRef]

466. Bala Ramasamy, Matthew Yeung. 2010. A causality analysis of the FDI-wages-productivity nexus in China. Journal of Chinese Economic and Foreign Trade Studies 3, 5-23. [CrossRef]

467. MICHAEL HÜBLER, ANDREAS KELLER. 2010. Energy savings via FDI? Empirical evidence from developing countries. Environment and Development Economics 15, 59. [CrossRef]

468. Meghana Ayyagari, Renáta Kosová. 2010. Does FDI Facilitate Domestic Entry? Evidence from the Czech Republic. Review of International Economics 18:10.1111/roie.2010.18.issue-1, 14-29. [CrossRef]

469. Naotaka Sawada. 2010. Technology Gap Matters on Spillover. Review of Development Economics 14:10.1111/rode.2010.14.issue-1, 103-120. [CrossRef] 
470. Joanna L. Y. Ho, Anne Wu, Sean Xin Xu. 2010. Corporate Governance and returns on information technology investment: evidence from an emerging market. Strategic Management Journal n/a-n/a. [CrossRef]

471. Wolfgang KellerInternational Trade, Foreign Direct Investment, and Technology Spillovers 793-829. [CrossRef]

472. Yan Zhang, Haiyang Li, Yu Li, Li-An Zhou. 2010. FDI spillovers in an emerging market: the role of foreign firms' country origin diversity and domestic firms' absorptive capacity. Strategic Management Journal n/a-n/a. [CrossRef]

473. Fakhraddin Maroofi, Shirzad Khsepehr. 2010. Social environment and industrial clusters: the effects on public investment distribution. International Journal of Business Performance Management 12, 123. [CrossRef]

474. Guoqing Zhao, Zhongyuan Zhang. 2010. Uncovering the Relationship between FDI, Human Capital and Technological Progress in Chinese High-technology Industries. China \& World Economy 18:10.1111/cwe.2010.18.issue-1, 82-98. [CrossRef]

475. Filip Abraham, Jozef Konings, Veerle Slootmaekers. 2010. FDI spillovers in the Chinese manufacturing sector. Economics of Transition 18:10.1111/ecot.2009.18.issue-1, 143-182. [CrossRef]

476. Chee-Keong Choong, Siew-Yong Lam, Zulkornain Yusop. 2010. Private capital flows to low-income countries: The role of domestic financial sector. Journal of Business Economics and Management 11, 598-612. [CrossRef]

477. Linghui Tang, Len J. Trevino. 2010. Asymmetries in Knowledge Dissemination from the Industrial Triad to Asia. The Journal of Economic Asymmetries 7:1, 1. [CrossRef]

478. Ann Harrison, Andrés Rodríguez-ClareTrade, Foreign Investment, and Industrial Policy for Developing Countries* 4039-4214. [CrossRef]

479. Shu-Chen Chang. 2010. Estimating Relationships Among FDI Inflow, Domestic Capital, and Economic Growth Using the Threshold Error Correction Approach. Emerging Markets Finance and Trade 46, 6-15. [CrossRef]

480. M. Ayhan Kose, Eswar Prasad, Kenneth Rogoff, Shang-Jin WeiFinancial Globalization and Economic Policies* 4283-4359. [CrossRef]

481. Kazuhiko Yokota, Akinori Tomohara. 2010. Modeling FDI-Induced Technology Spillovers. The International Trade Journal 24, 5-34. [CrossRef]

482. Peter J. Buckley, Jeremy Clegg, Ping Zheng, Pamela A. Siler, Gianluigi GiorgioniThe Impact of Foreign Direct Investment on the Productivity of China's Automotive Industry 284-304. [CrossRef]

483. Peter J. Buckley, Jeremy Clegg, Chengqi WangInward FDI and Host Country Productivity: Evidence from China's Electronics Industry 216-238. [CrossRef]

484. Peter J. Buckley, Jeremy Clegg, Chengqi WangIs the Relationship between Inward FDI and Spillover Effects Linear? An Empirical Examination of the Case of China 192-215. [CrossRef]

485. Peter J. Buckley, Chengqi Wang, Jeremy CleggThe Impact of Foreign Ownership, Local Ownership and Industry Characteristics on Spillover Benefits from Foreign Direct Investment in China 305-326. [CrossRef]

486. Juha Väätänen, Daria Podmetina, Marina AleksandrovaThe Role of FDI in the Development of Innovative Capacity: The Case of Russian Companies 221-237. [CrossRef]

487. Xiaolan Fu, Luc SoeteIntroduction 1-12. [CrossRef]

488. Chen Fang, Pierre MohnenFDI, R\&D and Innovation Output in the Chinese Automobile Industry 203-220. [CrossRef] 
489. Ka Zeng, Richard Sherman. 2009. Foreign direct investment and industry demands for trade protection. Review of International Political Economy 16, 778-802. [CrossRef]

490. Irene Brambilla, Galina Hale, Cheryl Long. 2009. Foreign Direct Investment and the Incentives to Innovate and Imitate*. Scandinavian Journal of Economics 111:10.1111/sjoe.2009.111.issue-4, 835-861. [CrossRef]

491. Beata S. Javorcik, Mariana Spatareanu. 2009. Tough Love: Do Czech Suppliers Learn from their Relationships with Multinationals?*. Scandinavian Journal of Economics 111:10.1111/ sjoe.2009.111.issue-4, 811-833. [CrossRef]

492. Massimo G. Colombo, Luca Grilli, Samuele Murtinu, Lucia Piscitello, Evila Piva. 2009. Effects of international R\&D alliances on performance of high-tech start-ups: a longitudinal analysis. Strategic Entrepreneurship Journal 3:10.1002/sej.v3:4, 346-368. [CrossRef]

493. Natalia Ramondo. 2009. Foreign Plants and Industry Productivity: Evidence from Chile. Scandinavian Journal of Economics 111:10.1111/sjoe.2009.111.issue-4, 789-809. [CrossRef]

494. Philip Shapira, Jue Wang. 2009. From lab to market? Strategies and issues in the commercialization of nanotechnology in China. Asian Business \& \&38; Management 8, 461-489. [CrossRef]

495. Garrick Blalock, Paul J. Gertler. 2009. How firm capabilities affect who benefits from foreign technology\#. Journal of Development Economics 90, 192-199. [CrossRef]

496. Jingjing Yang, Helian Xu, Chengang Wang, Mingyong Lai, Yingqi Wei. 2009. Productivity spillovers from foreign direct investment in Chinese industries. Journal of Chinese Economic and Business Studies 7, 429-446. [CrossRef]

497. Zeyong TianThe empirical research of FDI technology spillover to private economy in Jiangsu province 196-200. [CrossRef]

498. Mahmut Yaşar, Catherine J. Morrison Paul. 2009. Size and Foreign Ownership Effects on Productivity and Efficiency: An Analysis of Turkish Motor Vehicle and Parts Plants. Review of Development Economics 13:10.1111/rode.2009.13.issue-4, 576-591. [CrossRef]

499. Yabin Zhang, Jiang Wu, Hongshan Ai. 2009. The technology gap and the limit of imitation: An inspection of the strategy of 'exchanging market for technology'. Journal of Chinese Economic and Business Studies 7, 447-455. [CrossRef]

500. Gábor Békés, Jörn Kleinert, Farid Toubal. 2009. Spillovers from Multinationals to Heterogeneous Domestic Firms: Evidence from Hungary. World Economy 32:10.1111/twec.2009.32.issue-10, 1408-1433. [CrossRef]

501. Shandre M. Thangavelu, Yik Wei Yong, Aekapol Chongvilaivan. 2009. FDI, Growth and the Asian Financial Crisis: The Experience of Selected Asian Countries. World Economy 32:10.1111/ twec.2009.32.issue-10, 1461-1477. [CrossRef]

502. Rachel Griffith, Stephen Redding, Helen Simpson. 2009. TECHNOLOGICAL CATCH-UP AND GEOGRAPHIC PROXIMITY.Journal of Regional Science 49:10.1111/jors.2009.49.issue-4, 689-720. [CrossRef]

503. Dolores Añón Higón. 2009. Productivity, Ownership and National Chains: Evidence from the British Retail Sector. Applied Economics Quarterly 55, 313-334. [CrossRef]

504. Jens Matthias Arnold, Beata S. Javorcik. 2009. Gifted kids or pushy parents? Foreign direct investment and plant productivity in Indonesia\#. Journal of International Economics 79, 42-53. [CrossRef]

505. Frank L. BARTELS, Nobuya HARAGUCHI, Hiroshi Kan SATO, Anders ISAKSSON, Tatsufumi YAMAGATA. 2009. INDUSTRIAL COMPETITIVENESS AND OPENNESS OF ECONOMIES IN AFRICA AND ASIA: AN INTRODUCTION. The Developing Economies 47:10.1111/ deve.2009.47.issue-3, 237-243. [CrossRef] 
506. Da-zhi Chu, Chang YangIntra- and inter-industry externalities: An empirical study on FDI in the manufacturing industry in Guangdong Province 1024-1031. [CrossRef]

507. Albert Guangzhou Hu, Gary H. Jefferson. 2009. A great wall of patents: What is behind China's recent patent explosion?\#. Journal of Development Economics 90, 57-68. [CrossRef]

508. Klaus E Meyer, Evis Sinani. 2009. When and where does foreign direct investment generate positive spillovers? A meta-analysis. Journal of International Business Studies 40:7, 1075-1094. [CrossRef]

509. Carlo Altomonte, Enrico Pennings. 2009. Domestic plant productivity and incremental spillovers from foreign direct investment. Journal of International Business Studies 40:7, 1131-1148. [CrossRef]

510. Garrick Blalock, Daniel H Simon. 2009. Do all firms benefit equally from downstream FDI? The moderating effect of local suppliers' capabilities on productivity gains. Journal of International Business Studies 40:7, 1095-1112. [CrossRef]

511. Xiaming Liu, Chengang Wang, Yingqi Wei. 2009. Do local manufacturing firms benefit from transactional linkages with multinational enterprises in China?. Journal of International Business Studies 40:7, 1113-1130. [CrossRef]

512. ANTONIO CUBEL, M. TERESA SANCHIS. 2009. Investment and growth in Europe during the Golden Age. European Review of Economic History 13, 219. [CrossRef]

513. Nuno Crespo, Maria Paula Fontoura, Isabel Proença. 2009. FDI spillovers at regional level: Evidence from Portugal. Papers in Regional Science 88:10.1111/pirs.2009.88.issue-3, 591-607. [CrossRef]

514. Rosa Bernardini Papalia, Silvia Bertarelli. 2009. The Role of Local Agglomeration Economies and Regional Characteristics in Attracting FDI: Italian Evidence. International Journal of the Economics of Business 16, 161-188. [CrossRef]

515. Derek K. Kellenberg. 2009. An empirical investigation of the pollution haven effect with strategic environment and trade policy. Journal of International Economics 78, 242-255. [CrossRef]

516. James B. Ang. 2009. Foreign direct investment and its impact on the Thai economy: the role of financial development. Journal of Economics and Finance 33, 316-323. [CrossRef]

517. HongYu Jia, JingMei MaFDI spillovers and economic growth in China 541-545. [CrossRef]

518. Ruth Rios-Morales, Louis Brennan. 2009. Ireland's innovative governmental policies promoting internationalisation. Research in International Business and Finance 23, 157-168. [CrossRef]

519. Davin Chor. 2009. Subsidies for FDI: Implications from a model with heterogeneous firms. Journal of International Economics 78, 113-125. [CrossRef]

520. Xiaolan Fu, Yundan Gong. 2009. International and Intranational Technological Spillovers and Productivity Growth in China *. Asian Economic Papers 8, 1-23. [CrossRef]

521. JOTA ISHIKAWA, YOICHI SUGITA, LAIXUN ZHAO. 2009. Corporate Control, Foreign Ownership Regulations and Technology Transfer. Economic Record 85:10.1111/ ecor.2009.85.issue-269, 197-209. [CrossRef]

522. Noor Aini Khalifah, Radziah Adam. 2009. Productivity Spillovers from FDI in Malaysian Manufacturing: Evidence from Micro-panel Data. Asian Economic Journal 23:10.1111/ asej.2009.23.issue-2, 143-167. [CrossRef]

523. Sumon Kumar Bhaumik, Ralitza Dimova. 2009. Economic reforms as a tool to attract foreign direct investment: is it a chimera?. Applied Economics Letters 16, 951-957. [CrossRef]

524. Can Huang, Naubahar Sharif. 2009. Manufacturing dynamics and spillovers: The case of Guangdong Province and Hong Kong, Macau, and Taiwan (HKMT). Research Policy 38, 813-828. [CrossRef]

525. Bin Qiu, Shuai Yang, Peijiang Xin, Berna Kirkulak. 2009. FDI technology spillover and the productivity growth of China's manufacturing sector. Frontiers of Economics in China 4, 209-227. [CrossRef] 
526.\#\#\#, SANG-BUM PARK, Hae Young Lee. 2009. A Panel Data Analysis on Spillover Effects and Determinants of Capital Productivity on Foreign Direct Investment Firms in Korea Industry. Productivity Review 23, 5-27. [CrossRef]

527. Xiaowen Tian, Shuanglin Lin. 2009. FDI Technology Spillovers Within And Across Industries: Evidence From China. Journal of Asia Business Studies 3, 29-36. [CrossRef]

528. Jonathan Batten, Xuan Vinh Vo. 2009. An analysis of the relationship between foreign direct investment and economic growth. Applied Economics 41, 1621-1641. [CrossRef]

529. Yufen Chen, Jin Chen. 2009. The impact of FDI on regional technological capabilities: evidence from China. Journal of Knowledge-based Innovation in China 1, 143-158. [CrossRef]

530. JAEJOON WOO. 2009. PRODUCTIVITY GROWTH AND TECHNOLOGICAL DIFFUSION THROUGH FOREIGN DIRECT INVESTMENT. Economic Inquiry 47:10.1111/ ecin.2009.47.issue-2, 226-248. [CrossRef]

531. Tien Quang Tran. 2009. Sudden Surge in FDI and Infrastructure Bottlenecks: The Case in Vietnam. Asean Economic Bulletin 26, 58-76. [CrossRef]

532. Grazia D. Santangelo. 2009. MNCs and linkages creation: Evidence from a peripheral area. Journal of World Business 44, 192-205. [CrossRef]

533. Jennifer Oetzel, Jonathan P. Doh. 2009. MNEs and development: a review and reconceptualization. Journal of World Business 44, 108-120. [CrossRef]

534. Ping Li, Guocai Yu. 2009. The dynamics of China's expenditure on R\&D. Frontiers of Economics in China 4, 97-109. [CrossRef]

535. Miao Wang. 2009. Manufacturing FDI and economic growth: evidence from Asian economies. Applied Economics 41, 991-1002. [CrossRef]

536. NIGEL DRIFFIELD, JAMES H. LOVE, KARL TAYLOR. 2009. PRODUCTIVITY AND LABOUR DEMAND EFFECTS OF INWARD AND OUTWARD FOREIGN DIRECT INVESTMENT ON UK INDUSTRY*. The Manchester School 77:10.1111/manc.2009.77.issue-2, 171-203. [CrossRef]

537. Sailesh Tanna. 2009. The impact of foreign direct investment on total factor productivity growth. Managerial Finance 35, 297-311. [CrossRef]

538. Sadayuki Takii. 2009. Multinationals, Technology Upgrading, and Wages in Urban and Rural Indonesia. Review of Development Economics 13:10.1111/rode.2009.13.issue-1, 151-163. [CrossRef]

539. Chul-Woo Kwon, Bong Geul Chun. 2009. Local Content Requirement under Vertical Technology Diffusion. Review of Development Economics 13:10.1111/rode.2009.13.issue-1, 111-124. [CrossRef]

540. Nigel Driffield, P.C. (Michelle) Chiang. 2009. The Effects of Offshoring to China: Reallocation, Employment and Productivity in Taiwan. International Journal of the Economics of Business 16, 19-38. [CrossRef]

541. Natália Barbosa, Vasco Eiriz. 2009. Linking corporate productivity to foreign direct investment: An empirical assessment. International Business Review 18, 1-13. [CrossRef]

542. Philippe Aghion, Richard Blundell, Rachel Griffith, Peter Howitt, Susanne Prantl. 2009. The Effects of Entry on Incumbent Innovation and Productivity. Review of Economics and Statistics 91, 20-32. [CrossRef]

543. Jürgen Bitzer, Holger Görg. 2009. Foreign Direct Investment, Competition and Industry Performance. World Economy 32:10.1111/twec.2009.32.issue-2, 221-233. [CrossRef]

544. Naser Abumustafa, Mohamed Mostafa. 2009. Do Domestic Firms Benefit from Multinational Enterprises? A Meta-Analysis of the Empirical Research. Journal of Transnational Management 14, 3-15. [CrossRef] 
545. Marouane ALAYA, Dalila NICET-CHENAF, Eric ROUGIER. 2009. À quelles conditions les IDE stimulent-ils la croissance ?. Mondes en développement 148, 119. [CrossRef]

546. Facundo Albornoz, Matthew A. Cole, Robert J. R. Elliott, Marco G. Ercolani. 2009. In Search of Environmental Spillovers. World Economy 32:10.1111/twec.2009.32.issue-1, 136-163. [CrossRef]

547. Jamal Bouoiyour, Hicham Hanchane, El Mouhoub Mouhoud. 2009. Investissements directs étrangers et productivité. Revue économique 60, 109. [CrossRef]

548. Yusheng PengForeign direct investment and SOE performance in China: Ecvidence from the Third Industrial Census 105-127. [CrossRef]

549. J MARKUSEN, N TROFIMENKO. 2009. Teaching locals new tricks: Foreign experts as a channel of knowledge transfers. Journal of Development Economics 88, 120-131. [CrossRef]

550. Laura Alfaro, Sebnem Kalemli-Ozcan, Selin Sayek. 2009. FDI, Productivity and Financial Development. World Economy 32:10.1111/twec.2009.32.issue-1, 111-135. [CrossRef]

551. Wang Wei, Yapa M.W.Y. BandaraFDI Spillovers - The Strategy for Chinese Economic Development 111-134. [CrossRef]

552. Klara Sabirianova Peter, Jan Svejnar, Katherine TerrellDistance to the Efficiency Frontier and Foreign Direct Investment and Spillovers 71-81. [CrossRef]

553. Andy Sumner, Meera TiwariDoing Globalisation 165-196. [CrossRef]

554. Eric Rugraff, Diego Sánchez-Ancochea, Andy SumnerWhat Do We Know about the Developmental Impacts of TNCs? 29-55. [CrossRef]

555. Petr PavlínekRegional Development Effects of Foreign Direct Investment in Central and Eastern Europe 166-193. [CrossRef]

556. Andrew Burke, Holger Görg, Aoife Hanley. 2008. The impact of foreign direct investment on new firm survival in the UK: evidence for static versus dynamic industries. Small Business Economics 31, 395-407. [CrossRef]

557. Kristien Coucke, Leo Sleuwaegen. 2008. Offshoring as a survival strategy: evidence from manufacturing firms in Belgium. Journal of International Business Studies 39:8, 1261-1277. [CrossRef]

558. 2008. Book Reviews. Journal of Economic Literature 46:4, 989-1041. [Abstract] [View PDF article] [PDF with links]

559. Mihir A. Desai, C. Fritz Foley, Kristin J. Forbes. 2008. Financial Constraints and Growth: Multinational and Local Firm Responses to Currency Depreciations. Review of Financial Studies 21, 2857-2888. [CrossRef]

560. Shady Kholdy, Ahmad Sohrabian. 2008. Foreign direct investment, financial markets, and political corruption. Journal of Economic Studies 35, 486-500. [CrossRef]

561. Yanping Li, Dan Shi, Jianhu CaiTechnology spillovers from international outsourcing: An empirical verification in China 616-621. [CrossRef]

562. Charles C. Okeahalam. 2008. Internationalisation and firm performance: Evidence from estimates of efficiency in banking in Namibia and Tanzania. Journal of International Development 20:10.1002/ jid.v20:7, 942-964. [CrossRef]

563. Katrijn Gielens, Linda M Van de Gucht, Jan-Benedict E.M Steenkamp, Marnik G Dekimpe. 2008. Dancing with a Giant: The Effect of Wal-Mart's Entry into the United Kingdom on the Performance of European Retailers. Journal of Marketing Research 45, 519-534. [CrossRef]

564. Liuyong Yang, Yanping ZouPanel Data Analysis of the FDI Spillover Effect on Economic Growth of 12 Asian Countries 1-4. [CrossRef] 
565. W. H. Furtan, J. Sauer. 2008. Determinants of Food Industry Performance: Survey Data and Regressions for Denmark. Journal of Agricultural Economics 59:10.1111/jage.2008.59.issue-3, 555-573. [CrossRef]

566. Yan ZhouThe R\&\#38;D spillovers study of foreign direct investment in Chinese manufacturing sector 1591-1596. [CrossRef]

567. Khaled Elmawazini, Pran Manga, Samir Saadi. 2008. Multinational Enterprises, Technology Diffusion, and Host Country Absorptive Capacity: A Note. Global Economic Review 37, 379-386. [CrossRef]

568. Klaus Desmet, Felipe Meza, Juan A. Rojas. 2008. Foreign direct investment and spillovers: gradualism may be better. Canadian Journal of Economics/Revue canadienne d'économique 41, 926-953. [CrossRef]

569. Y LUH, C CHANG, F HUANG. 2008. Efficiency change and productivity growth in agriculture: A comparative analysis for selected East Asian economies. Journal of Asian Economics 19, 312-324. [CrossRef]

570. Sjoerd Beugelsdijk, Roger Smeets, Remco Zwinkels. 2008. The impact of horizontal and vertical FDI on host's country economic growth. International Business Review 17, 452-472. [CrossRef]

571. Ying Ge, Yasheng Chen. 2008. Foreign Ownership and Productivity of Joint Ventures. Economic Development and Cultural Change 56:10.1086/588244, 895-920. [CrossRef]

572. Xiaohui Liu, Huan Zou. 2008. The impact of greenfield FDI and mergers and acquisitions on innovation in Chinese high-tech industries. Journal of World Business 43, 352-364. [CrossRef]

573. Matthias Busse, Jos Luis Groizard. 2008. Foreign Direct Investment, Regulations and Growth. World Economy 31:10.1111/twec.2008.31.issue-7, 861-886. [CrossRef]

574. A CHARI, N GUPTA. 2008. Incumbents and protectionism: The political economy of foreign entry liberalization\#. Journal of Financial Economics 88, 633-656. [CrossRef]

575. Densil Williams, Derrick Deslandes. 2008. Motivation for Service Sector Foreign Direct Investments in Emerging Economies: Insights from the Tourism Industry in Jamaica. The Round Table 97, 419-437. [CrossRef]

576. P. Faria, W. SofkaAppropriability mechanisms of multinational firms \&\#8212; A cross country comparison 1-5. [CrossRef]

577. Sergio Mariotti, Marco Mutinelli, Lucia Piscitello. 2008. The Internationalization of Production by Italian Industrial Districts' Firms: Structural and Behavioural Determinants. Regional Studies 42, 719-735. [CrossRef]

578. R. Smeets. 2008. Collecting the Pieces of the FDI Knowledge Spillovers Puzzle. The World Bank Research Observer 23, 107-138. [CrossRef]

579. Daniel Chudnovsky, Andres Lopez, Gaston Rossi. 2008. Foreign Direct Investment Spillovers and the Absorptive Capabilities of Domestic Firms in the Argentine Manufacturing Sector (1992-2001). Journal of Development Studies 44, 645-677. [CrossRef]

580. Sourafel Girma, Yundan Gong. 2008. FDI, Linkages and the Efficiency of State-Owned Enterprises in China. Journal of Development Studies 44, 728-749. [CrossRef]

581. Sea Jin Chang, Dean Xu. 2008. Spillovers and competition among foreign and local firms in China. Strategic Management Journal 29:10.1002/smj.v29:5, 495-518. [CrossRef]

582. N. A. Phelps. 2008. Cluster or Capture? Manufacturing Foreign Direct Investment, External Economies and Agglomeration. Regional Studies 42, 457-473. [CrossRef]

583. Deborah L. Swenson. 2008. Multinationals and the creation of Chinese trade linkages. Canadian Journal of Economics/Revue canadienne d'économique 41, 596-618. [CrossRef] 
584. Matthew A. Cole, Robert J.R. Elliott, Eric Strobl. 2008. The environmental performance of firms: The role of foreign ownership, training, and experience. Ecological Economics 65, 538-546. [CrossRef]

585. Henry Thompson. 2008. Economic Growth with Foreign Capital. Review of Development Economics 0, 080414152145312-???. [CrossRef]

586. C. Pietrobelli, F. Saliola. 2008. Power relationships along the value chain: multinational firms, global buyers and performance of local suppliers. Cambridge Journal of Economics 32, 947-962. [CrossRef]

587. Garrick Blalock, Paul J. Gertler, David I. Levine. 2008. Financial constraints on investment in an emerging market crisis\#. Journal of Monetary Economics 55, 568-591. [CrossRef]

588. M KAFOUROS, P BUCKLEY. 2008. Under what conditions do firms benefit from the research efforts of other organizations?. Research Policy 37, 225-239. [CrossRef]

589. Eva A. Paus, Kevin P. Gallagher. 2008. Missing Links: Foreign Investment and Industrial Development in Costa Rica and Mexico. Studies in Comparative International Development 43, 53-80. [CrossRef]

590. Ari Kokko, Victoria Kravtsova. 2008. Innovative capability in MNC subsidiaries: evidence from four European transition economies. Post-Communist Economies 20, 57-75. [CrossRef]

591. Vasilios Kosteas. 2008. Foreign direct investment and productivity spillovers: a quantile analysis. International Economic Journal 22, 25-41. [CrossRef]

592. Sourafel Girma, Holger Görg, Mauro Pisu. 2008. Exporting, linkages and productivity spillovers from foreign direct investment. Canadian Journal of Economics/Revue canadienne d'économique 41, 320-340. [CrossRef]

593. Z LIU. 2008. Foreign direct investment and technology spillovers: Theory and evidence. Journal of Development Economics 85, 176-193. [CrossRef]

594. Farrokh Nourzad. 2008. Openness and the Efficiency of FDI: A Panel Stochastic Production Frontier Study. International Advances in Economic Research 14, 25-35. [CrossRef]

595. B JAVORCIK, M SPATAREANU. 2008. To share or not to share: Does local participation matter for spillovers from foreign direct investment?\#. Journal of Development Economics 85, 194-217. [CrossRef]

596. Timothy C. Ford, Jonathan C. Rork, Bruce T. Elmslie. 2008. Foreign Direct Investment, Economic Growth, and the Human Capital Threshold: Evidence from US States*. Review of International Economics 16, 96-113. [CrossRef]

597. Chengqi Wang, Zhongxiu Zhao. 2008. Horizontal and vertical spillover effects of foreign direct investment in Chinese manufacturing. Journal of Chinese Economic and Foreign Trade Studies 1, 8-20. [CrossRef]

598. Y. Wei, X. Liu, C. Wang. 2008. Mutual productivity spillovers between foreign and local firms in China. Cambridge Journal of Economics 32, 609-631. [CrossRef]

599. Mahmut Yasar, Catherine J Morrison Paul. 2008. Foreign Technology Transfer and Productivity. Journal of Business and Economic Statistics 26, 105-112. [CrossRef]

600. Jian Du, Huiping Li, Xiaobo Wu. 2008. Empirical analysis on the negative technology spillover effect of foreign direct investment in China. Asian Journal of Technology Innovation 16, 133-151. [CrossRef]

601. José María Cubillo-Pinilla. 2008. Small business performance in MNC suppliers' networks. Journal of Small Business and Enterprise Development 15:3, 571. [CrossRef]

602. Lamia Ben Hamida, Philippe GuglerFDI and spillovers in the Swiss manufacturing industry: Interaction effects between spillover mechanisms and domestic absorptive capacities 263-287. [CrossRef]

603. Charles Okeahalam, Mark Dowdeswell. 2008. A model of foreign direct investment flows at the municipal level in South Africa. Journal of Modelling in Management 3, 249-267. [CrossRef] 
604. Rajah Rasiah, Ashish Kumar. 2008. Foreign Ownership, Technological Intensities and Economic Performance of Automotive Parts Firms in India. Asia Pacific Business Review 14, 85-102. [CrossRef]

605.X. Yang, Y. ChengStudy on the Channels of International Technology Spillovers: A View from the Interaction of Trade and FDI 5469-5473. [CrossRef]

606. Bruce E. Moon. 2007. Reproducing the North-South Divide: The Role of Trade Deficits and Capital Flows1. International Studies Review 9:10.1111/misr.2007.9.issue-4, 581-600. [CrossRef]

607. Peter Blair Henry. 2007. Capital Account Liberalization: Theory, Evidence, and Speculation. Journal of Economic Literature 45:4, 887-935. [Abstract] [View PDF article] [PDF with links]

608. J.K. Mullen, Martin Williams. 2007. FOREIGN DIRECT INVESTMENT AND REGIONAL PRODUCTIVITY SPILLOVERS IN US MANUFACTURING. Review of Urban \& Regional Development Studies 19:10.1111/rurd.2007.19.issue-3, 185-196. [CrossRef]

609. Davide Castellani, Antonello Zanfei. 2007. Multinational companies and productivity spillovers: is there a specification error?. Applied Economics Letters 14, 1047-1051. [CrossRef]

610. Lei Zhu, Bang Nam Jeon. 2007. International R\&D Spillovers: Trade, FDI, and Information Technology as Spillover Channels. Review of International Economics 15:10.1111/roie.2007.15.issue-5, 955-976. [CrossRef]

611. László Halpern, Balázs Muraközy. 2007. Does distance matter in spillover?. The Economics of Transition 15:10.1111/ecot.2007.15.issue-4, 781-805. [CrossRef]

612. Trevor Buck, Xiaohui Liu, Yingqi Wei, Xiaming Liu. 2007. The trade development path and export spillovers in China: A missing link?. Management International Review 47, 683-706. [CrossRef]

613. Aseem Prakash, Matthew Potoski. 2007. Investing Up: FDI and the Cross-Country Diffusion of ISO 14001 Management Systems. International Studies Quarterly 51:10.1111/isqu.2007.51.issue-3, 723-744. [CrossRef]

614. D ANONHIGON. 2007. The impact of R\&D spillovers on UK manufacturing TFP: A dynamic panel approach. Research Policy 36, 964-979. [CrossRef]

615. Peter J. Buckley, Jeremy Clegg, Ping Zheng, Pamela A. Siler, Gianluigi Giorgioni. 2007. The impact of foreign direct investment on the productivity of China's automotive industry. Management International Review 47, 707-724. [CrossRef]

616. Jasjit Singh. 2007. Asymmetry of knowledge spillovers between MNCs and host country firms. Journal of International Business Studies 38:5, 764-786. [CrossRef]

617. S. Girma, Y. Gong, H. Gorg. 2007. Foreign Direct Investment, Access to Finance, and Innovation Activity in Chinese Enterprises. The World Bank Economic Review 22, 367-382. [CrossRef]

618. G BLALOCK, P GERTLER. 2007. Welfare gains from Foreign Direct Investment through technology transfer to local suppliers\#. Journal of International Economics . [CrossRef]

619. Roger Svensson. 2007. Knowledge transfer to emerging markets via consulting projects. The Journal of Technology Transfer 32, 545-559. [CrossRef]

620. Ronald B. Davies, Christopher J. Ellis. 2007. Competition in taxes and performance requirements for foreign direct investment. European Economic Review 51, 1423-1442. [CrossRef]

621. Jonathan E Haskel, Sonia C Pereira, Matthew J Slaughter. 2007. Does Inward Foreign Direct Investment Boost the Productivity of Domestic Firms?. Review of Economics and Statistics 89, 482-496. [CrossRef]

622. M JACOB, J GROIZARD. 2007. Technology transfer and multinationals: The case of Balearic hotel chains' investments in two developing economies. Tourism Management 28, 976-992. [CrossRef]

623. Philippe Gugler, Serge Brunner. 2007. FDI Effects on National Competitiveness: A Cluster Approach. International Advances in Economic Research 13, 268-284. [CrossRef] 
624. Sourafel Girma, Holger Görg. 2007. The Role of the Efficiency Gap for Spillovers from FDI: Evidence from the UK Electronics and Engineering Sectors. Open Economies Review 18, 215-232. [CrossRef]

625. Nicole Madariaga, Sandra Poncet. 2007. FDI in Chinese Cities: Spillovers and Impact on Growth. The World Economy 30:10.1111/twec.2007.30.issue-5, 837-862. [CrossRef]

626. Yanling Wang. 2007. Trade, Human Capital, and Technology Spillovers: an Industry-level Analysis. Review of International Economics 15:10.1111/roie.2007.15.issue-2, 269-283. [CrossRef]

627. Peter J Buckley, Jeremy Clegg, Chengqi Wang. 2007. Is the relationship between inward FDI and spillover effects linear? An empirical examination of the case of China. Journal of International Business Studies 38:3, 447-459. [CrossRef]

628. Nigel Driffield, James H Love. 2007. Linking FDI motivation and host economy productivity effects: conceptual and empirical analysis. Journal of International Business Studies 38:3, 460-473. [CrossRef]

629. Mahmut Yasar, Catherine J. Morrison Paul. 2007. International linkages and productivity at the plant level: Foreign direct investment, exports, imports and licensing. Journal of International Economics 71, 373-388. [CrossRef]

630. X LIU, T BUCK. 2007. Innovation performance and channels for international technology spillovers: Evidence from Chinese high-tech industries. Research Policy 36, 355-366. [CrossRef]

631. John H. Dunning, Fabienne Fortanier. 2007. Multinational Enterprises and the New Development Paradigm: Consequences for Host Country Development. Multinational Business Review 15, 25-46. [CrossRef]

632. Nuno Crespo, Maria Paula Fontoura. 2007. Determinant Factors of FDI Spillovers - What Do We Really Know?. World Development 35, 410-425. [CrossRef]

633. Changyuan Luo. 2007. FDI, domestic capital and economic growth: Evidence from panel data at China's provincial level. Frontiers of Economics in China 2, 92-113. [CrossRef]

634. Sumon Kumar Bhaumik, Saul Estrin, Klaus E Meyer. 2007. Determinants of Employment Growth at MNEs: Evidence from Egypt, India, South Africa and Vietnam. Comparative Economic Studies 49:1, 61-80. [CrossRef]

635. Chengqi Wang, Li Yu. 2007. Do spillover benefits grow with rising foreign direct investment? An empirical examination of the case of China. Applied Economics 39, 397-405. [CrossRef]

636. Jun Du, Sourafel Girma. 2007. Finance and Firm Export in China. Kyklos 60:10.1111/ kykl.2007.60.issue-1, 37-54. [CrossRef]

637. Joanna Scott-Kennel. 2007. Foreign direct investment and local linkages: An empirical investigation. Management International Review 47, 51-77. [CrossRef]

638. Chiara Di Guardo, Giovanni Valentini. 2007. Taking Actively Advantage of MNCs' Presence. Small Business Economics 28, 55-68. [CrossRef]

639. Kevin Amess, Barbara M. Roberts. 2007. The impact of foreign and state ownership on post-transition industrial concentration: the case of Polish manufacturing. Economic Change and Restructuring 38, 211-225. [CrossRef]

640. Thierry Tressel, Thierry Verdier. 2007. Financial Globalization and the Governance of Domestic Financial Intermediaries. IMF Working Papers 07, 1. [CrossRef]

641. Richard Kneller, Mauro Pisu. 2007. Industrial Linkages and Export Spillovers from FDI. The World Economy 30:10.1111/twec.2007.30.issue-1, 105-134. [CrossRef]

642. Xiaowen Tian. 2007. Accounting for sources of FDI technology spillovers: evidence from China. Journal of International Business Studies 38:1, 147-159. [CrossRef] 
643. Samuel Mulenga Bwalya. 2006. Foreign direct investment and technology spillovers: Evidence from panel data analysis of manufacturing firms in Zambia. Journal of Development Economics 81, 514-526. [CrossRef]

644. Nicholas Apergis, Costantinos P. Katrakilidis, Nikolaos M. Tabakis. 2006. Dynamic Linkages between FDI Inflows and Domestic Investment: A Panel Cointegration Approach. Atlantic Economic Journal 34, 385-394. [CrossRef]

645. Huay Huay Lee, Hui Boon Tan. 2006. Technology Transfer, FDI and Economic Growth in the ASEAN Region. Journal of the Asia Pacific Economy 11, 394-410. [CrossRef]

646. Chuck C Y Kwok, Solomon Tadesse. 2006. The MNC as an agent of change for host-country institutions: FDI and corruption. Journal of International Business Studies 37:6, 767-785. [CrossRef]

647. Claire Economidou, Vivian Lei, Janet S. Netz. 2006. International Integration and Growth: A Further Investigation on Developing Countries. International Advances in Economic Research 12, 435-448. [CrossRef]

648. Josef C. Brada, Ali M. Kutan, Taner M. Yigit. 2006. The effects of transition and political instability on foreign direct investment inflows. The Economics of Transition 14:10.1111/ecot.2006.14.issue-4, 649-680. [CrossRef]

649. Yasuyuki Todo, Koji Miyamoto. 2006. Knowledge Spillovers from Foreign Direct Investment and the Role of Local R\&D Activities: Evidence from Indonesia. Economic Development and Cultural Change 55:10.1086/edcc.2006.55.issue-1, 173-200. [CrossRef]

650. Juan Alcácer. 2006. Location Choices Across the Value Chain: How Activity and Capability Influence Collocation. Management Science 52, 1457-1471. [CrossRef]

651. Francisco M. Veloso. 2006. UNDERSTANDING LOCAL CONTENT DECISIONS: ECONOMIC ANALYSIS AND AN APPLICATION TO THE AUTOMOTIVE INDUSTRY. Journal of Regional Science 46:10.1111/jors.2006.46.issue-4, 747-772. [CrossRef]

652. Eddy LEE, et Marco VIVARELLI. 2006. Les conséquences sociales de la mondialisation dans les pays en développement. Revue internationale du Travail 145:10.1111/ilrf.2006.145.issue-3, 191-210. [CrossRef]

653. Joshua Aizenman, Mark M. Spiegel. 2006. Institutional Efficiency, Monitoring Costs and the Investment Share of FDI. Review of International Economics 14:10.1111/roie.2006.14.issue-4, 683-697. [CrossRef]

654. Eddy LEE, Marco VIVARELLI. 2006. Impacto social de la globalización en los países en desarrollo. Revista Internacional del Trabajo 125:10.1111/ilrs.2006.125.issue-3, 187-206. [CrossRef]

655. Eddy LEE, Marco VIVARELLI. 2006. The social impact of globalization in the developing countries. International Labour Review 145:10.1111/ilr.2006.145.issue-3, 167-184. [CrossRef]

656. Robert Lensink, Oliver Morrissey. 2006. Foreign Direct Investment: Flows, Volatility, and the Impact on Growth*. Review of International Economics 14:10.1111/roie.2006.14.issue-3, 478-493. [CrossRef]

657. M KUGLER. 2006. Spillovers from foreign direct investment: Within or between industries?. Journal of Development Economics 80, 444-477. [CrossRef]

658. Sytse Douma, Rejie George, Rezaul Kabir. 2006. Foreign and domestic ownership, business groups, and firm performance: evidence from a large emerging market. Strategic Management Journal 27:10.1002/ smj.v27:7, 637-657. [CrossRef]

659. Oonkyu Lee, Jeongdong Lee, Inha OhThe Role of FDI on Transferring Technology to Korea 1887-1891. [CrossRef]

660. S BARRIOS, L BERTINELLI, E STROBL. 2006. Coagglomeration and spillovers. Regional Science and Urban Economics 36, 467-481. [CrossRef] 
661. Yingqi Wei, Xiaming Liu, Chengang Wang. 2006. Trade Orientation and Mutual Productivity Spillovers between Foreign and Local Firms in China. Journal of Asia Business Studies 1, 46-53. [CrossRef]

662. Y Wei, X Liu. 2006. Productivity spillovers from R\&D, exports and FDI in China's manufacturing sector. Journal of International Business Studies 37:4, 544-557. [CrossRef]

663. E BROOKS. 2006. Why don't firms export more? Product quality and Colombian plants. Journal of Development Economics 80, 160-178. [CrossRef]

664. C CARPANO, M RAHMAN, K ROTH, J MICHEL. 2006. International competition in mature, localized industries: Evidence from the U.S. furniture industry. Journal of Business Research 59, 630-637. [CrossRef]

665. Anabel Marin, Martin Bell. 2006. Technology spillovers from Foreign Direct Investment (FDI): the active role of MNC subsidiaries in Argentina in the 1990s. The Journal of Development Studies 42, 678-697. [CrossRef]

666. T MULLER, M SCHNITZER. 2006. Technology transfer and spillovers in international joint ventures. Journal of International Economics 68, 456-468. [CrossRef]

667. L BRANSTETTER. 2006. Is foreign direct investment a channel of knowledge spillovers? Evidence from Japan's FDI in the United States\#. Journal of International Economics 68, 325-344. [CrossRef]

668. Nigel Driffield. 2006. On the search for spillovers from foreign direct investment (FDI) with spatial dependency. Regional Studies 40, 107-119. [CrossRef]

669. Quan Li. 2006. Democracy, Autocracy, and Tax Incentives to Foreign Direct Investors: A CrossNational Analysis. The Journal of Politics 68. . [CrossRef]

670. Blandina Oliveira, Adelino Fortunato. 2006. Testing Gibrat's Law: Empirical Evidence from a Panel of Portuguese Manufacturing Firms. International Journal of the Economics of Business 13, 65-81. [CrossRef]

671. Saibal Kar, Basudeb Guha-Khasnobis. 2006. Economic Reform, Skill Formation and Foreign Capital. The World Economy 29:10.1111/twec.2006.29.issue-1, 79-94. [CrossRef]

672. Bao Qun, Peng Shui-junA Comparative Panel Data Estimation on Technology Spillover Effects of FDI and Import in China 1076-1081. [CrossRef]

673. M. Ayhan Kose, Eswar Prasad, Kenneth Rogoff, Shang-Jin Wei. 2006. Financial Globalization: A Reappraisal. IMF Working Papers 06, 1. [CrossRef]

674. Abdur Chowdhury, George Mavrotas. 2006. FDI and Growth: What Causes What? The World Economy 29:10.1111/twec.2006.29.issue-1, 9-19. [CrossRef]

675. Roghieh Gholami, Sang-Yong Tom Lee, Almas Heshmati. 2006. The Causal Relationship Between Information and Communication Technology and Foreign Direct Investment. The World Economy 29:10.1111/twec.2006.29.issue-1, 43-62. [CrossRef]

676. Mihir A. Desai, C. Fritz Foley, James R. Hines. 2006. Capital Controls, Liberalizations, and Foreign Direct Investment. Review of Financial Studies 19, 1433-1464. [CrossRef]

677. Guan Jian-cheng, Hou Run-xiuSpillover Effects of FDI on the R\&D Capacity of Domestic Firms: The Case of China 1118-1122. [CrossRef]

678. Jesus Ferreiro, Carmen Gomez, Carlos RodriguezThe Pattern of Inward FDI Geographical Distribution: Can Developing Countries Base Their Development on Those Flows? 149-164. [CrossRef]

679. Jože P. Damijan, Andreja Jaklič, Matija RojecDo External Knowledge Spillovers Induce Firms' Innovations? Evidence from Slovenia 27-47. [CrossRef] 
680. Jing-Lin DuanmuCountry of Origin Effects on Knowledge Transfers from MNEs to their Chinese Suppliers: an Exploratory Investigation 162-179. [CrossRef]

681. Holger Gorg, Eric Strobl. 2005. Spillovers from Foreign Firms through Worker Mobility: An Empirical Investigation*. Scandinavian Journal of Economics 107:10.1111/sjoe.2005.107.issue-4, 693-709. [CrossRef]

682. Richard Perkins, Eric Neumayer. 2005. The International Diffusion of New Technologies: A Multitechnology Analysis of Latecomer Advantage and Global Economic Integration. Annals of the Association of American Geographers 95, 789-808. [CrossRef]

683. Ian Goldin, Kenneth Reinert. 2005. Global capital flows and development: A Survey. Journal of International Trade \& Economic Development 14, 453-481. [CrossRef]

684. I ALVAREZ, J MOLERO. 2005. Technology and the generation of international knowledge spillovers: An application to Spanish manufacturing firms. Research Policy 34, 1440-1452. [CrossRef]

685. Andreas Savvides, Marios Zachariadis. 2005. International Technology Diffusion and the Growth of TFP in the Manufacturing Sector of Developing Economies. Review of Development Economics 9:10.1111/rode.2005.9.issue-4, 482-501. [CrossRef]

686. T GAO. 2005. Foreign direct investment and growth under economic integration. Journal of International Economics 67, 157-174. [CrossRef]

687. Katsuhiro Miyamoto, Huangjin Liu. 2005. An Analysis of the Determinants of Provincial-Level Performance in China's Economy. Comparative Economic Studies 47:3, 520-542. [CrossRef]

688. J AIZENMAN. 2005. Opposition to FDI and financial shocks. Journal of Development Economics 77, 467-476. [CrossRef]

689. Natália Barbosa, Helen Louri. 2005. Corporate Performance: Does Ownership Matter? A Comparison of Foreign- and Domestic-Owned Firms in Greece and Portugal. Review of Industrial Organization 27, 73-102. [CrossRef]

690. Mark Aguiar, Gita Gopinath. 2005. Fire-Sale Foreign Direct Investment and Liquidity Crises. Review of Economics and Statistics 87, 439-452. [CrossRef]

691. Joshua Aizenman. 2005. Financial Liberalisations in Latin America in the 1990s: A Reassessment. The World Economy 28:10.1111/twec.2005.28.issue-7, 959-983. [CrossRef]

692. Sourafel Girma. 2005. Absorptive Capacity and Productivity Spillovers from FDI: A Threshold Regression Analysis*. Oxford Bulletin of Economics and Statistics 67:10.1111/obes.2005.67.issue-3, 281-306. [CrossRef]

693. Andrew Sumner. 2005. Is foreign direct investment good for the poor? A review and stocktake. Development in Practice 15, 269-285. [CrossRef]

694. Alexandre O. Vera-Cruz, Gabriela Dutrénit. 2005. Spillovers from MNCs through worker mobility and technological and managerial capabilities of SMEs in Mexico. Innovation: Management, Policy \& Practice 7, 274-297. [CrossRef]

695. Klara Sabirianova, Jan Svejnar, Katherine Terrell. 2005. Distance to the Efficiency Frontier and Foreign Direct Investment Spillovers. Journal of the European Economic Association 3:10.1162/ jeea.2005.3.issue-2-3, 576-586. [CrossRef]

696. S TAKII. 2005. Productivity spillovers and characteristics of foreign multinational plants in Indonesian manufacturing 1990?1995. Journal of Development Economics 76, 521-542. [CrossRef]

697. Guest Editors, Ana Teresa Tavares, Stephen Young. 2005. FDI and multinationals: patterns, impacts and policies. International Journal of the Economics of Business 12, 3-16. [CrossRef]

698. Lucia Piscitello, Larissa Rabbiosi. 2005. The impact of inward FDI on local companies' labour productivity: evidence from the Italian case. International Journal of the Economics of Business 12, 35-51. [CrossRef] 
699. Frances Ruane, Ali Uğur. 2005. Foreign direct investment and productivity spillovers in Irish manufacturing industry: evidence from plant level panel data. International Journal of the Economics of Business 12, 53-66. [CrossRef]

700. Ann P. Bartel, Ann E. Harrison. 2005. Ownership Versus Environment: Disentangling the Sources of Public-Sector Inefficiency. Review of Economics and Statistics 87, 135-147. [CrossRef]

701. Frank Barry, Holger Gorg, Eric Strobl. 2005. Foreign direct investment and wages in domestic firms in Ireland: Productivity spillovers versus labour-market crowding out. International Journal of the Economics of Business 12, 67-84. [CrossRef]

702. Constantina Kottaridi. 2005. The 'core-periphery' pattern of FDI-led growth and production structure in the EU. Applied Economics 37, 99-113. [CrossRef]

703. Kostas Axarloglou, Mike Pournarakis. 2005. Capital Inflows in the Balkans: Fortune or Misfortune?. The Journal of Economic Asymmetries 2:2, 21. [CrossRef]

704. Nagesh Kumar, Jaya Prakash PradhanForeign Direct Investment, Externalities and Economic Growth in Developing Countries: Some Empirical Explorations 42-84. [CrossRef]

705. José De GregorioThe Role of Foreign Direct Investment and Natural Resources in Economic Development 179-197. [CrossRef]

706. Holger Görg, Alexander HijzenMultinational Enterprises and Spillovers 92-113. [CrossRef]

707. Sumon Kumar BhaumikForeign Direct Investment: A Brief Overview of the Micro Issues 23-45. [CrossRef]

708. Rekha Mehta, Santosh BhandariTrends and Determinants of Foreign Direct Investment in Emerging Economies of Asia 180-197. [CrossRef]

709. Yasheng Huang, Tarun KhannaIndigenous versus Foreign Business Models 161-179. [CrossRef]

710. Laszlo Pook, Zsuzsanna Szabo. 2004. Information and Telecommunications Technology Infrastructures in Romania. Journal of East-West Business 10, 5-28. [CrossRef]

711. R BELDERBOS, M CARREE, B LOKSHIN. 2004. Cooperative R\&D and firm performance. Research Policy 33, 1477-1492. [CrossRef]

712. Salvador Barrios, Sophia Dimelis, Helen Louri, Eric Strobl. 2004. Efficiency spillovers from foreign direct investment in the EU periphery: A comparative study of Greece, Ireland, and Spain. Review of World Economics 140, 688-705. [CrossRef]

713. Jang C. Jin. 2004. On the Relationship Between Openness and Growth in China: Evidence from Provincial Time Series Data. The World Economy 27:10.1111/twec.2004.27.issue-10, 1571-1582. [CrossRef]

714. Lakhwinder Singh. 2004. Globalization, national innovation systems and response of public policy. International Journal of Technology Management and Sustainable Development 3:10.1386/ ijtm.2004.3.issue-3, 215-232. [CrossRef]

715. L ALFARO. 2004. FDI and economic growth: the role of local financial markets. Journal of International Economics 64, 89-112. [CrossRef]

716. Ting Gao. 2004. FDI, openness and income. Journal of International Trade \& Economic Development 13, 305-323. [CrossRef]

717. Wolfgang Keller. 2004. International Technology Diffusion. Journal of Economic Literature 42:3, 752-782. [Abstract] [View PDF article] [PDF with links]

718. Ashoka Mody. 2004. Is FDI Integrating the World Economy?. The World Economy 27:10.1111/ twec.2004.27.issue-8, 1195-1222. [CrossRef] 
719. Albert Guangzhou Hu. 2004. Multinational Corporations, Patenting, and Knowledge Flow: The Case of Singapore. Economic Development and Cultural Change 52:10.1086/edcc.2004.52.issue-4, 781-800. [CrossRef]

720. Camilla Jensen. 2004. Localized Spillovers in the Polish Food Industry: The Role of FDI in the Development Process?. Regional Studies 38, 533-548. [CrossRef]

721. Klaus E Meyer. 2004. Perspectives on multinational enterprises in emerging economies. Journal of International Business Studies 35:4, 259-276. [CrossRef]

722. Stefan Lutz, Oleksandr Talavera. 2004. Do Ukrainian Firms Benefit from FDI?. Economic Change and Restructuring 37, 77-98. [CrossRef]

723. Riccardo Cappellin. 2004. International knowledge and innovation networks for European integration, cohesion, and enlargement*. International Social Science Journal 56:10.1111/issj.2004.56.issue-180, 207-225. [CrossRef]

724. Robert E. Lipsey, Fredrik Sjöholm. 2004. FDI and wage spillovers in Indonesian manufacturing. Review of World Economics 140, 321-332. [CrossRef]

725. Sophia Dimelis, Helen Louri. 2004. Foreign direct investment and technology spillovers: Which firms really benefit?. Review of World Economics 140, 230-253. [CrossRef]

726. George R G Clarke. 2004. Effect of Enterprise Ownership and Foreign Competition on Internet Diffusion in the Transition Economies. Comparative Economic Studies 46:2, 341-370. [CrossRef]

727. Beata Smarzynska Javorcik. 2004. Does Foreign Direct Investment Increase the Productivity of Domestic Firms? In Search of Spillovers Through Backward Linkages. American Economic Review 94:3, 605-627. [Abstract] [View PDF article] [PDF with links]

728. Joan Enric Ricart, Michael J Enright, Pankaj Ghemawat, Stuart L Hart, Tarun Khanna. 2004. New frontiers in international strategy. Journal of International Business Studies 35:3, 175-200. [CrossRef]

729. Philippe Aghion, Richard Blundell, Rachel Griffith, Peter Howitt, Susanne Prantl. 2004. Entry and Productivity Growth: Evidence from Microlevel Panel Data. Journal of the European Economic Association 2:10.1162/jeea.2004.2.issue-2-3, 265-276. [CrossRef]

730. Roberto Alvarez, Raymond Robertson. 2004. Exposure to foreign markets and plant-level innovation: evidence from Chile and Mexico. Journal of International Trade \& Economic Development 13, 57-87. [CrossRef]

731. Riccardo Cappellin, Michael SteinerEnlarging the Scale of Knowledge and Innovation Networks: Theoretical Perspectives, Methodological Approaches and Policy Issues 263-286. [CrossRef]

732. Veena Keshav PailwarForeign Direct Investment, Resource Availability and Efficiency in India 112-133. [CrossRef]

733. Elissa Braunstein, Gerald EpsteinBargaining Power and Foreign Direct Investment in China: Can 1.3 Billion Consumers Tame the Multinationals? 209-248. [CrossRef]

734. Matthew J. SlaughterSkill Upgrading in Developing Countries: Has Inward Foreign Direct Investment Played a Role? 121-145. [CrossRef]

735. Karolina EkholmMultinational Enterprises and Their Effect on Labour Markets 74-95. [CrossRef]

736. Davide Castellani, Antonello Zanfei. 2003. Technology gaps, absorptive capacity and the impact of inward investments on productivity of European firms *. Economics of Innovation and New Technology 12, 555-576. [CrossRef]

737. Holger Gorg, Eric Strobl. 2003. Multinational Companies, Technology Spillovers and Plant Survival*. Scandinavian Journal of Economics 105:10.1111/sjoe.2003.105.issue-4, 581-595. [CrossRef]

738. Marcelo Soto. 2003. Taxing capital flows: an empirical comparative analysis. Journal of Development Economics 72, 203-221. [CrossRef] 
739. D. Barr, F. Breedon, D. Miles. 2003. Life on the outside: economic conditions and prospects outside euroland. Economic Policy 18, 573-613. [CrossRef]

740. Ksenia Yudaeva, Konstantin Kozlov, Natalia Melentieva, Natalia Ponomareva. 2003. Does foreign ownership matter?. The Russian experience*. The Economics of Transition 11:10.1111/ ecot.2003.11.issue-3, 383-409. [CrossRef]

741. G Gong. 2003. Convergence and polarization in global income levels: a review of recent results on the role of international technology diffusion. Research Policy 32, 1055-1079. [CrossRef]

742. X Liu. 2003. Does foreign direct investment facilitate technological progress? Evidence from Chinese industries. Research Policy 32, 945-953. [CrossRef]

743. Georgios I. Zekos. 2003. MNEs, globalisation and digital economy: legal and economic aspects. Managerial Law 45, 1-296. [CrossRef]

744. Wilbur Chung, W Mitchell, B Yeung. 2003. Foreign direct investment and host country productivity: the American automotive component industry in the 1980s. Journal of International Business Studies 34:2, 199-218. [CrossRef]

745. Selin Sayek, Laura Alfaro, Areendam Chanda, Sebnem Kalemli-Ozcan. 2003. FDI Spillovers, Financial Markets and Economic Development. IMF Working Papers 03, 1. [CrossRef]

746. Stephen R. Yeaple, Wolfgang Keller. 2003. Multinational Enterprises, International Trade, and Productivity Growth: Firm-Level Evidence From the United States. IMF Working Papers 03, 1. [CrossRef]

747. Nigel Driffield, Max Munday, Annette Roberts. 2002. Foreign Direct Investment, Transactions Linkages, and the Performance of the Domestic Sector. International Journal of the Economics of Business 9, 335-351. [CrossRef]

748. R Hasan. 2002. The impact of imported and domestic technologies on the productivity of firms: panel data evidence from Indian manufacturing firms. Journal of Development Economics 69, 23-49. [CrossRef]

749. Petr Pavlinek. 2002. The Role of Foreign Direct Investment in the Privatisation and Restructuring of the Czech Motor Industry. Post-Communist Economies 14, 359-379. [CrossRef]

750. Salvador Barrios, Eric Strobl. 2002. Foreign direct investment and productivity spillovers: Evidence from the Spanish experience. Weltwirtschaftliches Archiv 138, 459-481. [CrossRef]

751. Matthew Gorton, Ferenc Guba. 2002. Foreign Direct Investment (FDI) and the Restructuring of the Hungarian Dairy Processing Sector. Journal of East-West Business 7, 5-28. [CrossRef]

752. Duncan McVicar. 2002. Spillovers and foreign direct investment in UK manufacturing. Applied Economics Letters 9, 297-300. [CrossRef]

753. Sourafel Girma, Katharine WakelinAre there Regional Spillovers from FDI in the UK? 172-186. [CrossRef]

754. Henrik Braconier, Karolina Ekholm, Karen Helene Midelfart Knarvik. 2001. In search of FDItransmitted R\&D spillovers: A study based on Swedish data. Weltwirtschaftliches Archiv 137, 644-665. [CrossRef]

755. George R. G. Clarke. 2001. How institutional quality and economic factors impact technological deepening in developing countries. Journal of International Development 13:10.1002/jid.v13:8, 1097-1118. [CrossRef]

756. Bartlomiej Kaminski, Beata K. Smarzynska. 2001. Integration into Global Production and Distribution Networks through FDI: The Case of Poland. Post-Communist Economies 13, 265-288. [CrossRef]

757. Nigel Driffield. 2001. Inward investment, industry concentration and the speed of adjustment. Weltwirtschaftliches Archiv 137, 193-214. [CrossRef] 
758. Peter Egger, Michael Pfaffermayr. 2001. A note on labour productivity and foreign inward direct investment. Applied Economics Letters 8, 229-232. [CrossRef]

759. Ari Kokko, Mario Zejan, Ruben Tansini. 2001. Trade regimes and spillover effects of FDI: Evidence from Uruguay. Weltwirtschaftliches Archiv 137, 124-149. [CrossRef]

760. IMF. Research Dept.World Economic Outlook, October 2001: The Information Technology Revolution . [CrossRef]

761. International Monetary Fund. 2001. Finance \& Development, June 2001. Finance \& Development 38, i. [CrossRef]

762. Magnus Blomström, Ari Kokko, Steven GlobermanThe determinants of host country spillovers from foreign direct investment: a review and synthesis of the literature 34-65. [CrossRef]

763. Nigel DriffieldRegional policy and the impact of FDI in the UK 162-177. [CrossRef]

764. B Xu. 2000. Multinational enterprises, technology diffusion, and host country productivity growth. Journal of Development Economics 62, 477-493. [CrossRef]

765. E. Nur Ozkan-Gunay, Yusuf CukurcayirForeign Direct Investment as a Development Strategy 13-29. [CrossRef]

766. Tomasz Dorożyński, Anetta Kuna-MarszałekInvestment Attractiveness of Visegrad Group Countries: 239-288. [CrossRef]

767. Bahar Bayraktar Saglam, Selin SayekSkill and Foreign Firm Premium 185-215. [CrossRef]

768. Alper Sönmez, Mehmet Teoman PamukçuForeign Direct Investment and Technology Spillovers in the Turkish Manufacturing Industry 30-51. [CrossRef]

769. Kamal SaggiChapter 10 Intellectual Property Rights and International Technology Transfer via Trade and Foreign Direct Investment 329-355. [CrossRef]

770. Abel Usoro, Bridget AbiagamA Conceptual View of Knowledge Management Adoption in Hospitality Industry of Developing Economies 39-56. [CrossRef]

771. Rob van Tulder, Andrea da RosaThe Role of Cross-Sector Partnership Portfolios in the Inclusive Business Strategies of Multinational Enterprises 153-180. [CrossRef]

772. Tomasz Dorożyński, Anetta Kuna-MarszałekInvestment Attractiveness of Visegrad Group Countries: 740-775. [CrossRef]

773. Abd Rahim JaguliChannel for Vertical Spillovers: 111-132. [CrossRef]

774. Lamia Ben HamidaBuilding R\&D Capabilities Abroad and the Role of Reverse Knowledge Transfer in Explaining MNCs' Productivity 219-235. [CrossRef]

775. Sumru OzDiffusion of Technology via FDI and Convergence of Per Capita Incomes: 236-264. [CrossRef]

776. Hasan Bakır, Filiz EryılmazCausal Relationship between Foreign Direct Investment and Economic Growth: 319-330. [CrossRef]

777. Kadir Y. Eryigit, Sibel Bali EryigitForeign Direct Investment, Financial Development and Economic Growth: 331-348. [CrossRef]

778. Natalya Smith, Ekaterina ThomasExploring the Social Impact of Foreign Direct Investment on Institutional Change: 198-214. [CrossRef] 